\title{
"A Snake Charmer with a Camera" Nina Leen's Contributions to Life Magazine: 1940-1972
}

\author{
By Erin Levitsky \\ B.A., Western University, 2014
}

\author{
A thesis presented to \\ Ryerson University \\ in partial fulfillment of the requirements of \\ Master of Arts in the Program of \\ Film and Photography Preservation and Collections Management
}

Toronto, Ontario, Canada, 2018

(C) Erin Levitsky 2018 


\section{Author's Declaration}

I hereby declare that I am the sole author of this thesis. This is a true copy of the thesis, including any required final revisions, as accepted by my examiners.

I authorize Ryerson University to lend this thesis to other institutions or individuals for the purpose of scholarly research.

I further authorize Ryerson University to reproduce this thesis by photocopying or by other means, in total or in part, at the request of other institutions or individuals for the purpose of scholarly research.

I understand that my thesis may be made electronically available to the public. 


\begin{abstract}
“A Snake Charmer with a Camera"; Nina Leen's Contributions to Life Magazine: 19401972

Master of Arts, 2018

Erin Levitsky

Film and Photography Preservation and Collections Management

Ryerson University
\end{abstract}

Nina Leen (c. 1909-1995) was a Russian-born émigré photographer who worked for Life magazine from 1940-1972, contributing photographs to stories published in 374 issues. Leen's photography received little attention following her death, as her working method, oeuvre, and character depart from those of the archetypal photojournalist. Using digital reproductions of Leen's photographic prints and negatives from the Life Photo Collection, a full run of Life, and archival documents housed in the Time Inc. Records at the New-York Historical Society, this thesis evaluates Leen's contributions to both Life magazine and the field of photojournalism. An introduction, literature survey, and methodological description contextualize Leen's career. Two appendices and a list of figures present images selected in this thesis, and the issues and sections of Life in which Leen's photographs were published. Three chapters discuss the beginning of Leen's career and her typical approach to magazine photography, and two chapters analyze the years leading up to Life's conclusion as a weekly magazine, when Leen held more command over her output. 


\section{Acknowledgements}

This project could not have become what it did without the help of numerous advisors, experts, and supporters. I am especially grateful to Thierry Gervais for his guidance, expertise, and meticulous critiques, and to Marilyn Kushner for making me feel at home and for sharing her unbounded wisdom.

I also wish to thank my second reader, Don Snyder, for contributing his thoughts, Bill Hooper, Jill Golden, and the entire library staff at the New-York Historical Society for facilitating the research process, and Gareth Roberts for revising with care.

I am tremendously grateful To Peter Higdon, the Roloff Beny Foundation, the Ontario Graduate Scholarship, and the FPPCM Program, whose financial support allowed me to carry out my research from New York City.

And to Susie, Neil, Rachel, Bram, Ilana, Naoise, Pippa, Jenna, and Mira, thank you for your enduring support (emotional and otherwise). 


\section{Table of Contents}

List of Illustrations ...........................................................................................

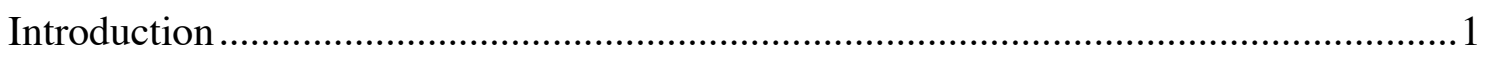

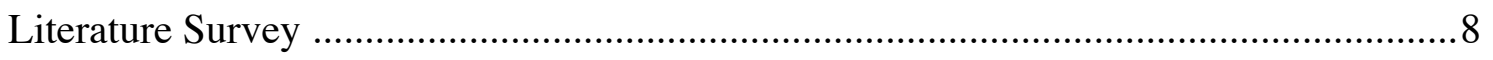

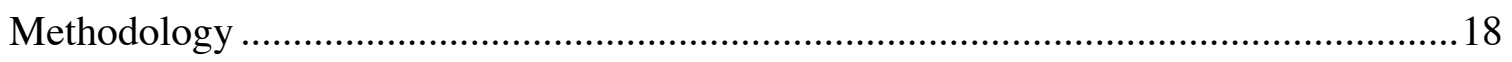

\section{Part I: 1934-1955}

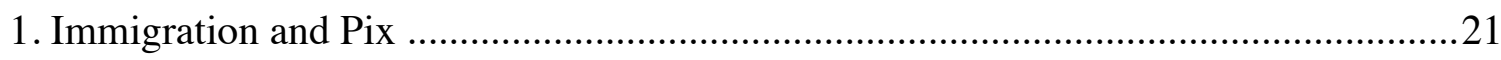

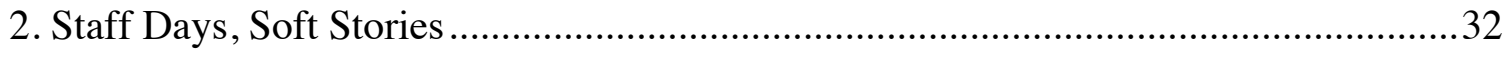

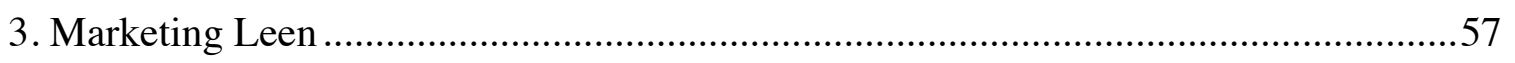

\section{PART II: 1955-1972}

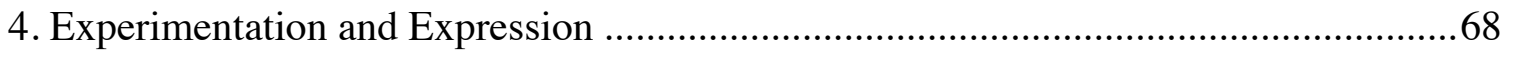

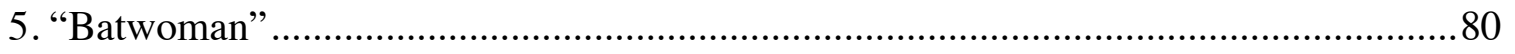

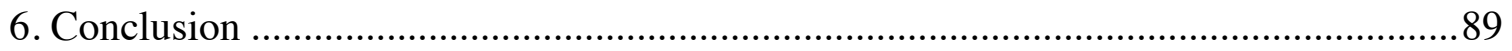

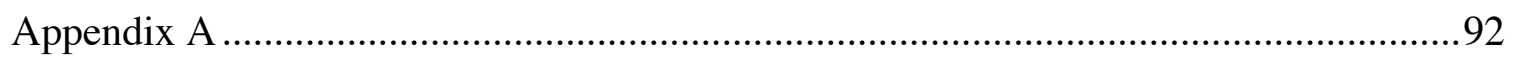

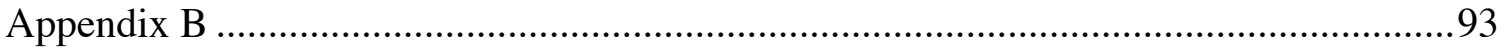

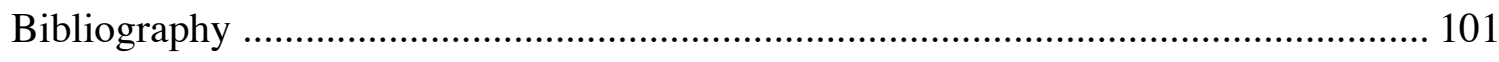




\section{List of Illustrations}

The photographs discussed in this paper are owned by a corporate archive and are not currently accessible to researchers. I relied on digital reproductions of photographic prints and negatives, for which information about format, material, and size was unavailable.

Figure 1: William Sumits, "Life Photographers, 1960," in The World of Time Inc.: The Intimate History of the Publishing Enterprise Volume Two: 1941-1960 by Robert T. Elson (New York: Atheneum, 1973), black and white plate 35.

Figure 2: Nina Leen, “Teen-Age Girls,” Life, December 11, 1944, 94-95.

Figure 3: Nina Leen, “Scarf Sun Clothes,” Life, July 7, 1944, 65.

Figure 4: "Slacks," Life, April 20, 1942, 62-63.

Figure 5: "Women Lose Pockets and Frills to Save Fabrics," Life, April 20, 1942, 70-71.

Figures 6-8: Nina Leen, "Slacks," digital reproduction from black and white negatives, April 1942. Life Photo Collection, Google Arts and Culture.

Figure 9: Nina Leen, “Summer Beach Fashions,” Life, May 15, 1950, 140-141.

Figure 10: Nina Leen, “Summer Beach Fashions,” Life, May 15, 1950, 142-143.

Figures 11-12: Nina Leen, "Summer Beach Fashions," digital reproductions from black and white negatives, May 1950. Life Photo Collection, Google Arts and Culture.

Figure 13: Nina Leen, “Summer Beach Fashions,” Life, May 15, 1950, 144-145.

Figure 14: Nina Leen, "Four Generations of an Ozark Farming Family," digital reproduction from black and white transmission, July 1948. Life Photo Collection, Google Arts and Culture.

Figure 15: Nina Leen, “The American Family in Trouble,” Life, July 26, 1948, 84-85.

Figure 16: "Installation view of the exhibition The Family of Man." January 24, 1955May 8, 1955. Photographic Archive. The Museum of Modern Art Archives, New York. IN569.48. Photograph by Rolf Petersen.

Figure 17: Grey Villet, “The Crime of Being Married,” Life, March 18, 1966, 88-89.

Figure 18: Nina Leen, “The Irascibles," digital reproduction from black and white negative, 1950. Life Photo Collection, Google Arts and Culture. 
Figure 19: Nina Leen, “Photographic Fabrics," Life, December 8, 1947, 106-107.

Figure 20: Nina Leen, “Photographic Fabrics,” Life, December 8, 1947, 108-109.

Figure 21: Nina Leen, “Photographic Fabrics," Life, December 8, 1947, 110-111.

Figures 22-23: "Photographic Fashions," digital reproductions from black and white negatives, December 1, 1947. Life Photo Collection.

Figure 24: Nina Leen, "New French Hat for Spring," digital reproduction from black and white negative, April 1948. Life Photo Collection, Google Arts and Culture.

Figure 25: Nina Leen, “Spring Fashions," Life, April 12, 1948, 90.

Figure 26: “Life's Pictures," Life, October 22, 1945, 29.

Figure 27: Nina Leen, “Life Goes House Fixing,” Life, August 20, 1945, 118-119.

Figure 28: Nina Leen, "Life Goes House Fixing," digital reproduction from black and white negative, July 1945, Life Photo Collection, Google Arts and Culture.

Figure 29: Nina Leen, “Life Goes House Fixing,” Life, August 20, 1945, 120-121.

Figure 30: Nina Leen, "Pet Squirrel," Life, January 31, 1944, 93.

Figure 31: Nina Leen, "Dazzling Collection of Pheasants from Asia is Assembled in North Carolina" Life, October 15, 1956, 123.

Figure 32: Nina Leen, "Ghostly American Legends: The Early Tales Die Hard Even in This Skeptical Age," Life, October 28, 1957, 90-91.

Figures 33-35: Nina Leen, "Ghostly American Legends," digital reproductions from colour transparencies, 1957. Life Photo Collection, Google Arts and Culture.

Figure 36: Nina Leen, “A Picture Portrayal of Moments of Happiness," Life, October 27, 1958, 94-95.

Figure 37: Philippe Halsman, "Hypnosis: Out of Ancient Magic Comes a New Medical Tool," Life, November 3, 1958.

Figure 38: Nina Leen and Ray Mackland, Lucky, the Famous Foundling (New York, A. A. Wyn, 1951), 50-51.

Figure 39: Nina Leen, Images of Sound (New York: Norton, 1977), 5-6. 
Figure 40: Nina Leen, Women, Heroes, and a Frog (New York: W.W. Norton, 1970), 67.

Figure 41: Nina Leen, “The Strange World of Bats,” Life, March 29, 1968, 52-53.

Figure 42: Nina Leen, “The Strange World of Bats,” Life, March 29, 1968, 58-59.

Figures 43-45: Nina Leen, "The World of Bats," digital reproductions from colour transparencies, 1968. Life Photo Collection, Google Arts and Culture.

Figure 46: Nina Leen, "African Spitting Cobra," digital reproduction from colour transparency, 1963. Life Photo Collection, Google Arts and Culture. 


\section{$\underline{\text { Introduction }}$}

Publishing magnate Henry Luce's objective for Life, which was launched in 1936, was to have "the cream of all the world's pictures brought together for [the U.S. citizen] to enjoy and study in one comfortable sitting." To do so, Time Inc. required a host of employees with well-trained eyes and inquisitive minds. Freelancers came and went over the thirtysix years that Life was published weekly, and only a fraction were hired as staff photographers. While Nina Leen technically worked under the conditions of an all-rights contract, which allowed her to create photographs for other publications simultaneously whereas a staff photographer could not, she was typically treated as a staff photographer. For example, her name was listed alongside other staff photographers in Life's masthead beginning in 1948, and made consistent appearances there until 1970.

Leen is also included in two Life publications that focused on staff photographers. In his introduction to The Great Life Photographers, former Life photographer John Loengard writes "this book includes biographical sketches of 88 of the 90 photographers who have been on Life's staff and 11 others who had a special relationship with the magazine." ${ }^{2}$ Leen is subsequently listed as one of those with a special relationship. ${ }^{3}$ An anecdote in Loengard's book Life Photographers: What They Saw, which consists of interviews with Life staff photographers, sheds similar light on the matter: "Nina Leen was an anomaly. A contract photographer, she was included in a photograph taken of the

\footnotetext{
${ }^{1}$ Henry Luce, “A Prospectus for a New Magazine," from New-York Historical Society, Henry R. Luce Papers, 1936.

${ }^{2}$ The Editors of Life, "The Ambition Behind This Book," in The Great Life Photographers, ed. John Loengard and Gordon Parks (New York: Time Warner Book Group, 2004), 11.

${ }^{3}$ In addition to Leen, the photographers said to have had special relationships with Life include Harry Benson, Milton Greene, Farrell Grehan, Philippe Halsman, Lisa Larsen, Gjon Mili, Lennart Nilsson, Mark Shaw, Burk Uzzle, and John Zimmerman. Ibid.
} 
staff photographers in 1960 , on the one occasion when they were gathered together from around the globe. Presumably everyone thought Leen was one of them"4 (Figure 1).

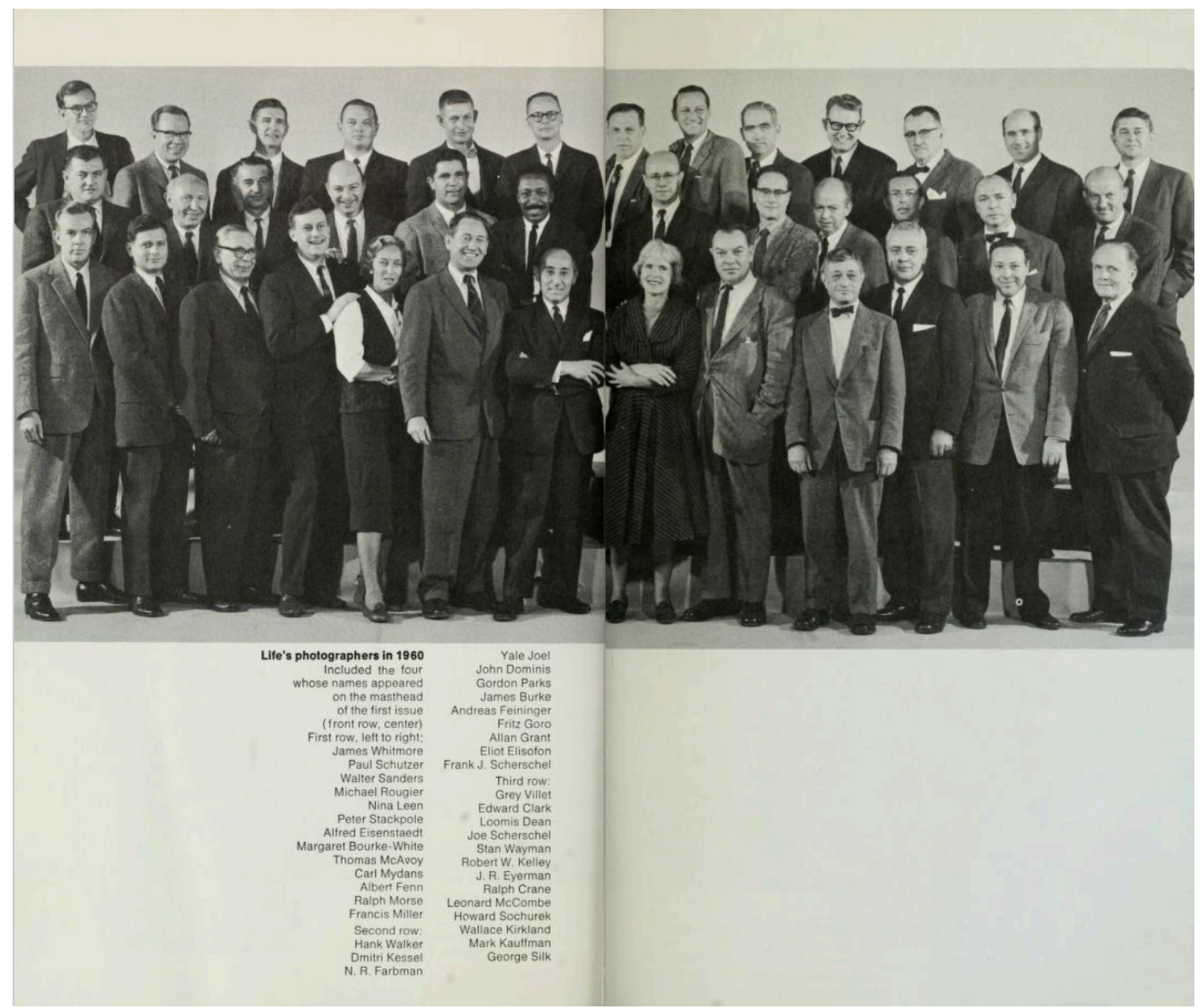

Figure 1: William Sumits, "Life Photographers, 1960," in The World of Time Inc.: The Intimate History of the Publishing Enterprise Volume Two: 1941-1960 by Robert T. Elson (New York: Atheneum, 1973) black and white plate 35. Leen is in the bottom row, fifth from the left.

Editors and executives at the magazine gained confidence in Nina Leen over the years. Her photographs were featured on forty-eight covers, she produced thirty-seven photographic essays - elaborate studies of a single subject involving "multiple

\footnotetext{
${ }^{4}$ John Loengard, "Introduction,” in Life Photographers: What They Saw, (Boston: Bulfinch Press, 1998), 8.
} 
photographs made from a variety of points of view, angles, and distances" ${ }^{\prime 5}$ and classified as photographic essays through the magazine's text or section headings in the table of contents - and she worked for Life for thirty-two years, until 1972 when its weekly editions were discontinued, and television fostered the demise of general news magazines. ${ }^{6}$

Yet Nina Leen's whirlwind career at Life magazine was far from expected for a woman in the post-war years. Having studied painting in Berlin before moving to America in 1939, Leen claims to have known nothing of photography when she began wandering the Bronx Zoo with a Rolleiflex camera that same year. ${ }^{7}$ Leen's photographs of a pair of 250-year-old turtles taken at the zoo appeared on the pages of Life magazine on April 1, 1940, launching her lengthy career in photojournalism and her distinctive working relationship with Life. ${ }^{8}$ For Leen, who left Germany on the eve of World War II, photography quickly became an opportunity that not all immigrants were afforded: she could earn a comfortable - even luxurious - living. ${ }^{9}$ Not only was photography a career that did not require high proficiency in English, it was also a role to which Leen could seamlessly apply her fine arts education.

Much of Nina Leen's photography can be found by thumbing through the 'Modern Living' section of Life, with fashion being her most recurrent subject both in this section and elsewhere in the magazine. Leen's photography can be located in more

\footnotetext{
${ }^{5}$ C. Zoe Smith, "Émigré Photography in America: Contributions of German Photojournalists from Black Star Picture Agency to Life Magazine" (PhD Diss., The University of Iowa, 1983), 5.

${ }^{6}$ Thierry Gervais with Gaëlle Morel, The Making of Visual News (London: Bloomsbury, 2017), 169.

7 "Unchecked and Uncorrected Transcript of Interview with Nina Leen" by John Loengard, interview, New-York Historical Society, The Time Inc. Archives, January 14, 1992.

${ }^{8}$ While Leen's interview with Loengard suggests otherwise, a caption affixed to Leen's photograph states she was "famed in Europe for her picture studies of animals in zoos." See "250-Year-Old Turtles at Bronx Zoo Fight for 200-Year-Old Female," Life, April 1, 1940, 46.

${ }^{9}$ Ray Mackland, "Ray Mackland to Bob Elfson," letter, from New-York Historical Society, The Time Inc. Archives, 1954.
} 
than half of the sections delineated by Life; her work was published eighty times in the 'Fashion' section, sixty times in 'Modern Living', and numerous times in various other sections from 'America' to 'Youth' ${ }^{10}$ Many of Leen's fashion and lifestyle photographs were even featured on the cover of the magazine. She also produced images of animals that garnered much attention from the public — scientists and educators held Leen's scientific studies of bats and snakes in high regard, while middlebrow readers swooned over her vernacular-style photographs of pets (her own included). ${ }^{11}$

Nina Leen's photography can also be found outside of Life magazine, as she selfpublished fifteen books between 1951 and 1981. These books exhibit almost as much diversity as Leen's Life photography, ranging from scientific studies of animals, to howto books for children, and even to inventive and abstract reinterpretations of her own past work.

The number of Leen's images published in Life between 1940 and 1972, when considered alongside the magazine's immense readership — an estimated twenty-six million individuals read the magazine each week in 1953 - is testament to the impact her photographs had on the American public. ${ }^{12}$ Yet although thirty-two years spent working for Life resulted in thousands of Leen's images being printed on its pages, her oncenotable professional recognition has since been eroded. This paper seeks to understand Nina Leen's exclusion from the history of photojournalism and its canon.

\footnotetext{
${ }^{10}$ These sections were determined by evaluating the magazine's "“Contents", pages; see Appendix A.

${ }^{11}$ Life's readers were predominantly middle-class Americans. For more on the circulation of the magazine, see: James L. Baughman, "Who Read Life? The Circulation of America's Favorite Magazine," in Looking at Life Magazine, ed. Erika Doss (Washington and London: Smithsonian Institute Press, 2001), 41-54.

${ }^{12}$ James L. Baughman, Henry R. Luce and the Rise of the American News Media (Baltimore: The Johns Hopkins University Press, 2001), 165.
} 
Naomi Rosenblum offers one explanation for Leen's contemporary obscurity, when she argues that magazine photography in general "has little staying power" as a result of "the pedestrian quality of the images and the absence of an art market for them." ${ }^{\prime 3}$ However, this theory conflicts with the evidence of photojournalists such as Margaret Bourke-White and Alfred Eisenstaedt, whose names are inseparable from Life, and yet who have received copious attention from contemporary scholars, curators, biographers, and art market professionals. While Rosenblum's theory can be better applied to case studies of other magazines and their respective photographers, Life offered its photographers a matchless opportunity to garner a reputation in the field of photojournalism - the promise of prestige lead both Leen and Eisenstaedt to leave the Pix picture agency to work for Life in the first place. ${ }^{14}$

Leen's classification as a photojournalist is manifested in two ways: by virtue of Life magazine being her employer and the primary publisher of her work, and through her self-described ability to tell a story using photographs. She published a large quantity of images in a magazine intended to share the week's news through photography, and her oeuvre is multifarious in terms of both form and function. Through an exploration of Leen's photojournalistic career and resulting photographic opus, this thesis seeks to understand her role at the magazine, and how the quantity and quality of her work contributed to the field of photojournalism during her time with Life. The remainder of this paper will comprise an analysis of Leen's work: it will outline Leen's technological aptitude, her distinctive style, and the subjects she regularly photographed in order to reveal how her work serves as a prime example of photojournalism that extends beyond

\footnotetext{
${ }^{13}$ Naomi Rosenblum, A History of Women Photographers (New York: Abbeville Press, 2010), 188.

${ }^{14}$ Smith, "Émigré Photography in America," 126.
} 
hard news, and expands the typical understanding of the genre. It will address how both the photographer's gender and the subjects of her images undermined her potential to achieve same level of recognition as Eisenstaedt and Life's other male photographers, despite her prominent position at such an influential magazine. It will also address the ways in which Leen's distinctive oeuvre departed from the valiant images of war and breaking news captured by the likes of Robert Capa, W. Eugene Smith, and Margaret Bourke-White, who have continued to hold the attention of historians and scholars. This paper argues that, barring some exceptions, Leen's photographs were meticulously composed, creatively formulated, and technologically sophisticated; they embody a middlebrow mode of photojournalism that was once vital for filling the pages of magazines like Life, yet their lack of attributes conventionally associated with photojournalism has resulted in a disregard for Leen's work by historians.

Directly following this introduction is a literature survey and an explanation of my methodology. The body of the paper is divided into two parts. The first deals with the beginning of Leen's career in photojournalism and covers her work from 1940 to 1954, during which time she created a large quantity of photographs while exercising less control over the subjects of her assignments. This section outlines Leen's immigration to America and employment as an agency photographer at Pix, discusses Leen being hired by Life and the manifold uses of her photographs in the magazine, and examines Life's approach toward marketing Leen and the effects of this publicity on her status as a photojournalist. The second part covers the latter portion of Leen's career at Life, a period when she produced fewer images but which best reflects the photographer's artistic sensibilities and passion for wildlife photography. This section begins in 1955 and ends 
in 1972, when the magazine ceased as a weekly publication, focuses on Leen's experimentation with expressive techniques and subjects, and explores her technical animal stories. Section Two is followed by a conclusion about Leen's contributions to Life magazine and the field of photojournalism, and appendices listing the issues and sections of the magazine in which her work was published. 


\section{$\underline{\text { Literature Survey }}$}

The following literature survey is an overview of the texts that contribute to an understanding of photojournalism before and during Nina Leen's career at Life magazine. In selecting theses sources, I considered the need to contextualize Leen in the field of photojournalism at large as well as within the confines of Life. I strove to develop a sense of what scholars tend to focus on when writing about photojournalism, photojournalists, and Life magazine, as well as what facets of the magazine have persistently been overlooked.

The first section considers sources that evaluate the history and theory of photojournalism, both in the pages of Life and outside this particular magazine. The second evaluates texts that concentrate specifically on individual photojournalists who worked for Life magazine; this part includes studies of other women staff photographers in order to understand whether Leen's gender affected her role at the magazine. The third offers an overview of the available sources that discuss Leen and her work.

\section{Photojournalism and Life Magazine}

Four texts provide a solid foundation on the history of photojournalism and developments in the historiography of the genre. Robert Lebeck and Bodo von Dewitz's Kiosk: A History of Photojournalism, ${ }^{15}$ and Christian Caujolle and Mary Panzer's Things As They Are: Photojournalism in Context since $1955,{ }^{16}$ present the history of photojournalism through reproductions of photographic essays or picture stories, emphasizing the

\footnotetext{
${ }^{15}$ Robert Lebeck and Bodo Von Dewitz, Kiosk: A History of Photojournalism (Göttingen: Steidl, 2001).

${ }^{16}$ Christian Caujolle and Mary Panzer, Things As They Are: Photojournalism in Context since 1955 (New York City: Aperture, 2005).
} 
construction and materiality of these essays. These books avoid foregrounding singular photographs created by individual photographers by emphasizing the collaborative nature of photojournalism and acknowledging the participation of writers, editors, art directors, and agencies. Kiosk begins by outlining the origins of photojournalism, and covers the history of the medium up to 1973, while Things as They Are celebrates the first fifty years of the World Press Photo contest by looking back on the history of photojournalism through 120 photographic essays published between 1955 and 2005. Both texts work to contextualize the field of photojournalism during the period in which Leen was employed by Life magazine by reproducing contemporaneous stories. These books offer concrete examples of the photojournalism that audiences consumed alongside those offered by Life and Leen.

Jason Hill and Vanessa R. Schwartz's Getting the Picture: The Visual Culture of the News ${ }^{17}$ and Thierry Gervais's (in collaboration with Gaëlle Morel) The Making of Visual News ${ }^{18}$ dissect the means by which picture stories, such as those reproduced in Kiosk and Things as They Are, have historically been produced. Getting the Picture does so by employing critical essays on the topic of news pictures - what they are, how they are selected and employed, and how they are equally valorized and reviled. In stepping away from the agendas of visual analysis and semiotic theory, Getting the Picture reveals how a researcher can use a variety of tactics - including analyzing the materiality of news images, and collaboration between editors and other involved parties - in order to reexamine historical photojournalism in a contemporary light. The following analysis of Leen's photography employs methodological approaches borrowed from the essays in

\footnotetext{
${ }^{17}$ Jason Hill and Vanessa R. Schwartz, Getting the Picture: The Visual Culture of the News (London and New York: Bloomsbury, 2015).

${ }^{18}$ Gervais, The Making of Visual News, 2017.
} 
Getting the Picture. The Making of Visual News focuses on the history and aesthetics of illustrated magazines. Gervais looks at the technical, economic, and cultural influences that have affected the development of photojournalism in order to assess the 'seduction potential' of news photographs. Particularly, a chapter focused on Life and the development of standardized practices that lead to the magazine's success offers invaluable information regarding the technological, political, economic, and bureaucratic climate at Leen's place of work.

Sheila Webb and C. Zoë Smith present two distinctive perspectives on the origins of Life magazine. In her journal article "Creating Life: 'America's Most Potent Editorial Force', ${ }^{19}$ Webb reveals Life's accomplishments and the decisions that drove the magazine - and the medium of the illustrated magazine - to success. She emphasizes the photographic essay as a factor that allowed Life to thrive, and discusses the defining ideology of the magazine as well as the political and social orientations of its most powerful staff - the editors. Webb's methodology is of prime importance for this thesis. She inspected every file relating to Life from the Time Inc. archives from 1932 to 1959 , as well as 262 issues and fifty-one thousand photographs, ${ }^{20}$ and therefore studied similar primary sources to the ones I have used to better comprehend Nina Leen's contributions to Life magazine. She contextualizes these archival documents with press releases, census statistics, and textbooks, as well as personal papers from Life's first managing editor, John Shaw Billings, ${ }^{21}$ a method which I imitated by utilizing newspaper articles, press releases, and other documents that offer insights into Leen's career.

\footnotetext{
${ }^{19}$ Sheila Webb, "Creating Life: 'America's Most Potent Editorial Force'," Journalism \& Communication Monographs 18 (2016): 55-108.

${ }^{20}$ Webb, "Creating Life," 59.

${ }^{21}$ Ibid.
} 
Smith’s dissertation “Émigré Photography in America: Contributions of German Photojournalists from Black Star Picture Agency to Life Magazine,"22 outlines the origins of Life by investigating the influence of German illustrated magazines and publishing houses and their staffs on Life. Her paper comprises a case study of the Black Star picture agency, in which she argues that it was the means by which practices popular in European photojournalism were incorporated into Life's pages. Smith gathered oral histories by conducting interviews with former Black Star photographers, identifying candid photographs and photographic essays as two of the significant elements introduced to America by German magazines' creators and contributors, and she asserted that Life's unique style of photojournalism was neither distinctly American nor characteristically European, but rather a fusion of the two. Smith's text helped me to contextualize Leen among her colleagues at Life as well as other agency and émigré photographers, and to understand the trajectory of her early career.

As with Webb and other Life scholars and historians, Smith is infatuated with the photographic essay. ${ }^{23}$ Although the tendency to concentrate on this segment is not without reason, the attention paid to the photographic essay points to a significant gap in the contemporary re-readings of Life magazine: What can be said about the rest of the magazine's photographic content? What goes overlooked and who becomes forgotten when scholars focus largely on photographic essays?

\footnotetext{
${ }^{22}$ Smith, "Émigré Photography in America," 1983.

${ }^{23}$ For other histories of photojournalism, Life, or Life photographers that draw attention to the photographic essay, see: Dolores Flamiano, "A Life of Their Own: Hansel Mieth's Photographic Essays," Media History Monographs 7 (2004): 1-29; and Wendy Kozol, Life's America: Family and Nation in Postwar Photojournalism (Philadelphia: Temple University Press, 1994).
} 
Erika Doss' analysis of Life's contents, in her Looking at Life Magazine, ${ }^{24}$ offers insight into the magazine's ideologies and inner workings. ${ }^{25}$ This book presents a reflection on the prevailing 'anxiety' surrounding representation and photography: while all photographs are inherently manipulated to some degree-photographers frame or even pose subjects, select shutter speeds, alter lighting, and so on-magazine images are also selected, cropped, lightened or darkened, enlarged, shrunk, and paired with accompanying text, titles, or captions. The essays in Looking at Life Magazine examine themes such as class, gender, race, and ethnicity, rather than focusing on large-scale events covered by the magazine. Rickie Solinger's discussion of the figure of the 'babe' and gender difference in Life contributed to a better understanding of how Leen's gender affected her work. James L. Baughman's examination of Life's readership informed me about the audiences who consumed Leen's photography. ${ }^{26}$ This book was a crucial tool in my research, because it supplied background information on the ideologies behind the publication. It encourages readers to scrutinize these ideologies in future investigations related to Life, and as the only existing anthology of theoretical analyses of Life it also reveals the countless topics that have yet to be studied in such a manner.

\footnotetext{
${ }^{24}$ Erika Doss, Looking at Life Magazine (Washington and London: Smithsonian Institute Press, 2001).

${ }^{25}$ For histories of Life and Time Inc., rather than analyses of its contents, see: Robert T. Elson, Time Inc.: The Intimate History of a Publishing Enterprise, 1923-1941 (New York: Atheneum, 1968); Robert T. Elson, The World of Time Inc.: The Intimate History of a Publishing Enterprise Volume Two: 1941-1960 (New York: Atheneum, 1973); Curtis Prendergast with Geoffrey Colvin, The World of Time Inc: The Intimate History of a Changing Enterprise: 1960-1980 (New York: Atheneum, 1986); James L. Baughman, Henry R. Luce and the Rise of the American News Media (Baltimore: Johns Hopkins University Press, 2001); and Loudon Wainwright, The Great American Magazine: An Inside History of Life (New York City: Knopf, 1986).

${ }^{26}$ Rickie Solinger, "The Smutty Side of Life: Picturing Babes as Icons of Gender Difference," in Looking at Life Magazine, ed. Erika Doss (Washington and London: Smithsonian Institute Press, 2001), 201-220; James L. Baughman, "Who Read Life? The Circulation of America's Favorite Magazine," in Looking at Life Magazine, ed. Erika Doss (Washington and London: Smithsonian Institute Press, 2001), 41-54.
} 


\section{Photojournalists and Life Magazine}

Case studies of Life photojournalists serve as excellent precedents for a thesis concerning Nina Leen-especially those regarding photographers whose qualities and characteristics align with Leen's. Tim Ream analyzes the (previously) obscure career of Werner Wolff in his master's thesis “The Life of Werner Wolff: An Analysis of Werner Wolff's Contributions to Life Magazine,"27 while Dolores Flamiano and Beth E. Wilson both survey women staff photographers who worked alongside Leen at Life.

Ream's dissertation considers why Wolff was denied the same fame that other Life photographers were granted, a question that can similarly be asked of Leen. He argues that although Wolff was denied the recognition many other Life photographers received, his photographs were invaluable to the magazine. To reach this conclusion, he examines illustrations, solo projects, and multi-photographer picture stories in which Wolff was involved, illustrating Life's need for variety and Wolff's ability to deliver just that. Ream views Wolff's technical photographic aptitude as his saving grace, and his lack of an identifiable oeuvre or aesthetic as his ultimate downfall. Ream's argument that Life's content, aside from the photographic essay, deserves more attention from scholars holds true for my project. Wolff's case also serves as a point of comparison, and ultimately departure, from which to analyze Leen's work. For example, unlike Wolff, the vast majority of Leen's photographs for Life were cohesive in terms of style; and while Wolff worked for the Black Star picture agency for over forty years, Leen was employed directly by Life after just five years at Pix. Studies of renowned Life photographers are

\footnotetext{
${ }^{27}$ Tim Ream, "The Life of Werner Wolff: An Analysis of Werner Wolff's Contributions to Life Magazine" (master's thesis, Ryerson University, 2014).
} 
common, but Ream's thesis offers insight into the relationships that a multitude of largely unrecognized photographers had with Life magazine.

Dolores Flamiano has written extensively about Hansel Mieth’s photographs, and her article "A Life of Their Own: Hansel Mieth’s Photographic Essays” provides an overview of Mieth's contributions to Life magazine. ${ }^{28}$ She analyzes three momentous photographic essays produced while Mieth was on staff at Life: "a 1939 feature about a rhesus monkey colony in Puerto Rico, a 1940 photographic essay about birth control in South Carolina, and a 1943 series of photographs about the World War II internment of Japanese Americans in Wyoming. ${ }^{29}$ In her text, Flamiano diverges from contemporary re-readings of Mieth's documentary photography penned by art historians, and instead focuses on Mieth's role as a photojournalist and the effects this position had on her photography. ${ }^{30}$ More Broadly, Flamiano's book Women, Workers, and Race in LIFE Magazine uses Mieth's photographs as a stepping-stone toward understanding the limitations faced by women at the time. ${ }^{31}$ Both of Flamiano's texts inform this study of Leen: "A Life of Their Own" describes the variety of photographic essays assigned to one of Leen's contemporaries; and Women, Workers, and Race in LIFE Magazine sheds light on the ways in which Leen's gender and personality affected her career at Life by offering a comparison with the more rebellious character of Hansel Mieth.

Beth E. Wilson's “The Corporate Creation of the Photojournalist: Life Magazine and Margaret Bourke-White in World War II" focuses on another of Leen's woman

\footnotetext{
${ }^{27}$ Dolores Flamiano, “A Life of Their Own: Hansel Mieth's Photographic Essays,” Media History Monographs 7 (2004): 1-29, http://facstaff.elon.edu/dcopeland/mhm/mieth.pdf.

${ }^{29}$ Ibid., 2 .

${ }^{30} \mathrm{Ibid}, 3$.

${ }^{31}$ Dolores Flamiano, Women, Workers, and Race in LIFE Magazine: Hansel Mieth's Reform Photojournalism, 1934-1955 (Abingdon: Routledge, 2016).
} 
colleagues. Wilson unpacks the cultural figure of the photojournalist in order to understand the iconic status achieved by Bourke-White. She argues that this mythologized character emerged in the 1930s - long after the conception of the genre of photojournalism itself — as a direct result of economic circumstances and marketing aims. Wilson contends that Life paradoxically worked to foster a myth of the heroic photojournalist, while in reality affording many of these individuals little or no power. She claims that Bourke-White's apparent power and autonomy represented the exception at Life, rather than the rule: most photographers were under the tight control of editors and the corporate hierarchy of the magazine. Wilson's article is useful for the contrasts it evokes between Leen and Bourke-White: unlike Bourke-White, Leen was never considered a celebrity photojournalist, nor is she remembered as one today. Wilson's reasoning behind Bourke-White's status sheds light on the preconditions for achieving such a superior rank. This text is a crucial tool used to position Leen amongst her colleagues at Life, as it provides an understanding of how Leen's work, as well as her personality, differed from Bourke-White's. Wilson's notion of Bourke-White's symbiotic relationship with Life is applied to Leen in the analysis of her career at the magazine that follows in this paper.

\section{Nina Leen}

Peer-reviewed and academic texts directly concerning Nina Leen are nonexistent, but two book chapters speak exclusively to her character and her work. The Great Life Photographers, compiled by the editors of Life and containing an introduction by John Loengard, includes a section dedicated to each of the Life staff photographers and the 
eleven other photographers who had special status at the magazine. ${ }^{32}$ According to Loengard, Nina Leen enjoyed a unique position at Life in that she was treated as if she was part of the magazine's staff, although she was never technically a staff photographer. The Great Life Photographers is more than a substantiation of the significance of Leen's work for Life magazine. The text dedicated to Leen and the photographs selected for reproduction reveal the essence of Leen's personality and work: the title given to Leen's chapter is "Dog Whisperer,"33 a reminder of her love of animals, though her fashion photographs are also featured. The Great Life Photographers offers a suitable introduction to the contents of Leen's oeuvre.

Loengard positions Leen as a significant figure in the history of Life magazine, and as an important contributor to twentieth century American photojournalism, by including a chapter about her in his 1998 book Life Photographers: What They Saw. In the early 1990s, Loengard set out to question staff photographers who had worked for Life, and each chapter of the resulting book contains an interview with one of Life's former staff photographers. Eight pages of text and images are dedicated to Nina Leen, and are thus the only published text with multiple pages that contain her own words, ${ }^{34}$ representing the greatest insight into the photographer's methods, logic, and attitudes available outside of the Time Inc. archives. Throughout her interview with Loengard, Leen voices her opinions on photography and gender issues. She speaks to Loengard of the toxic atmosphere between her and the male staff at Life, as well as the necessity for

\footnotetext{
${ }^{32}$ The Editors of Life, "The Ambition Behind This Book," in The Great Life Photographers, ed. John Loengard and Gordon Parks (New York: Time Warner Book Group, 2004), 11.

${ }^{33}$ The Editors of Life, "Nina Leen," in The Great Life Photographers, ed. John Loengard and Gordon Parks (New York: Time Warner Book Group, 2004), 308.

${ }^{34}$ John Loengard, ed., Life Photographers: What They Saw (Boston: Bulfinch Press, 1998).
} 
self-determination and perseverance, which ultimately paid off by allowing her to create stories that Life editors had initially rejected.

I also consulted additional biographical information published on various online platforms, including James Pomerantz's New Yorker article "The Surreal World of Nina Leen, ${ }^{35}$ Liz Ronk's "Photographer Spotlight: Nina Leen" on www.time.com ${ }^{36}$ and a profile by Alicia Josten for The International Center of Photography's website. ${ }^{37}$ Together with the aforementioned book chapters, these sources summarize Leen's output, and begin to paint a picture of her fascinating background and multifaceted character. Pomerantz describes Leen's photographs as mysterious and surreal, despite their "pedestrian" subject matter, ${ }^{38}$ Ronk emphasizes that fashion and animals were two subjects that frequently appeared in Leen's photographs, ${ }^{39}$ and Josten foregrounds Leen's versatility, as well as the outsider perspective she brought to photographing American culture. ${ }^{40}$ These more recent texts suggest a renewed contemporary interest in Leen's photography, and indicate areas of her work that will be examined more closely in this paper, such as her love of animals and her fine arts education.

\footnotetext{
${ }^{35}$ James Pomerantz, "The Surreal World of Nina Leen," The New Yorker, April 11, 2013, https://www.newyorker.com/culture/photo-booth/the-surreal-world-of-nina-leen. ${ }^{36}$ Liz Ronk, "Photographer Spotlight: Nina Leen," Time Life, November 18, 2012, http://time.com/3506134/photographer-spotlight-nina-leen/.

${ }^{37}$ Alicia Josten, "Nina Leen," International Center of Photography, accessed October 11, 2017, https://www.icp.org/browse/archive/constituents/nina-leen?all/all/all/all/0.

${ }^{38}$ Ibid.

${ }^{39}$ Ronk, "Photographer Spotlight: Nina Leen,” 2012.

${ }^{40}$ Josten, "Nina Leen."
} 


\section{Methodology}

Following a review of the available literature, the next logical step in analyzing Leen's work was to create an inventory of the photographic content she published in Life. To this end I created a custom Filemaker Pro ${ }^{\mathrm{TM}}$ database to catalogue Leen's Life photographs, using data extracted from the Ryerson Image Centre in which the photographers credited in every issue of Life had previously been recorded. The database is comprised of 374 records, each of which represents an issue in which Leen's photographs appear, beginning on April 1, 1940 and ending August 4, 1972. Fields including title, subject, scope, and section, cover (yes or no), provide further clarification as to Leen's contribution to that particular issue. Page number(s) and other photographers credited in the issue were also recorded, along with the date and issue number. Examining both the categories found in Life's 'Contents' pages and the subject matter of her photographs was crucial for analyzing Leen's photographic output for Life magazine, as an individual section in Life contained stories on numerous subjects, and single subjects often traversed more than one section.

I consulted Leen's files from the Time Inc. archive to complement this data and to better understand her relationship with Life and its executives, as well as to comprehend the public's reception of her photographs. Letters between Leen and other Life and Time Inc. staff are contained in this collection, as well as staff newsletters that mention the photographer's name. The Time Inc. archive also contains primary sources such as obituaries, book reviews, exhibition announcements, and clippings from Life, as well as other publications in which Leen was mentioned or where her work was reproduced. One e-mail in particular, which was printed and deposited in the Time Inc. archive in Leen's 
subject file, revealed the fate of her photographic collection: toward the end of her life, and as a result of her poor health and lack of living relatives, all rights to Leen's materials were signed over to Time Inc. In exchange, Leen received a higher revenue share for syndication, along with free and unrestricted access to Time Inc.'s photography lab. ${ }^{41}$

I also consulted each of Leen's fifteen self-published books in order to understand the existence of her photographs outside of Life magazine. Three books were published while Leen was still working for Life, beginning in 1951, and the remaining twelve were created between 1973 and 1981. The books range in content, target audience, and size, including an instructional text aimed at children called Taking Pictures, a fictional children's book illustrated with photographs, three conceptual photobooks, and ten books about animals. Leen's animal books also vary from simplistic illustrated accounts of dog and cat breeds to large, text- and diagram-heavy books intended for academic audiences.

Leen's estate is currently owned and cared for by the corporate archive of Meredith Corporation, ${ }^{42}$ and is is not physically accessible to researchers. Thankfully, all of her photographs - including prints, negatives, and transparencies - have been digitized, and are hosted by the Google Arts and Culture website as part of the Life Photo Collection. While the lack of access to physical photographs creates a limitation, scrutinizing the digital reproductions that form this body of work has nevertheless been revealing for this project. Locating negatives associated with specific assignments was made possible by cross-referencing Leen's assignment cards. These cards list every project Leen was assigned throughout her career at Life, along with their respective years

\footnotetext{
${ }^{41}$ Regina Feiler, "Rights to Leen's Material," e-mail, April 4, 2012, New-York Historical Society, The Time Inc. Archives, accessed January 28, 2018.

${ }^{42}$ Leen initially sold her estate to Time Inc., which Meredith Corporation acquired in 2018. The takeover occurred during the time that this research was being conducted.
} 
and a code used for archival purposes. Additionally, I had access to a full run of Life, available in digital format through Google Books and physically at the New-York Historical Society.

Following a thorough examination of the aforementioned materials, I chose to divide this study into two sections. The first part surveys the beginning of Leen's career at Life, from 1940 to 1954 , during which she was new to America, new to photography, and wholly dependent on the magazine for her livelihood. The second part deals with the changes in Leen's photographic production from 1955, when a notable decrease in the quantity of stories published in Life by Leen is evident, until the end of the magazine's weekly publication in 1972. Both of these sections seek to address the factors leading to Leen's exclusion from the histories of photojournalism, and to reveal how she contributed to the genre. 


\section{PART I: 1934-1955}

\section{Immigration and Pix}

Women have been involved in photography since the medium's conception, and Naomi Rosenblum conceives of two key bases for women's enduring interest in the field: opportunities for employment, and for expression..$^{43}$ Not all of Life's photographers yearned for the latter, but for Nina Leen, as a woman educated in painting, and as an émigré looking for work in America as the 1930s were ending, a career in photojournalism presented an auspicious prospect. At Life, the two elements suggested by Rosenblum came together, and Leen's economic freedom was attainable through a relatively creative enterprise.

Emigrating from Germany to the United States in 1939 was rarely an aspirational decision. The available biographical information about Leen is haphazard, so there is no evidence to support the notion that she fled persecution as a Jew. Jewish enrollment in German higher education declined rapidly following the onset of Adolf Hitler's rule, ${ }^{44}$ making it unlikely that Leen would have been able to attend university in Berlin during the five years leading up to her departure had she been Jewish. While Jewish emigration swelled in $1939,{ }^{45}$ scores of non-Jewish Germans also chose to evade the declining living conditions and the rise of Fascism, including some of Leen's soon-to-be Life colleagues. Hansel Mieth and her husband and periodic photographic collaborator Otto Hagel, for example, "left for the United States based more on personal desire to break free from

\footnotetext{
${ }^{43}$ Naomi Rosenblum, "Introduction," A History of Women Photographers (New York City: Abeville Press Publishers, 2010), 7.

${ }^{44}$ Trude Maurer, "Education and Vocational Training," in Jewish Daily Life in Germany, 1618-1945, ed. Marion A. Kaplan, trans. Allison Brown (Oxford: Oxford University Press, 2005), 304.

${ }^{45}$ Trude Maurer, "Constricting and Extinguishing Jewish Life," in Jewish Daily Life in Germany, 16181945, ed. Marion A. Kaplan, trans. Allison Brown (Oxford: Oxford University Press, 2005), 355.
} 
what they felt was an increasingly close-minded environment . . . than a grave need to escape the social oppression Hitler would impose on millions only a few years later."46 Leen may have left Berlin in 1939 out of utter desperation and fear for her life, but there is an equal chance she disagreed with Hitler's rising oppression and knew there were opportunities awaiting in America.

Leen's voyage to New York came at an auspicious time. Not only did her first few years in New York coincide with better employment prospects for women as American men were increasingly sent off to war, ${ }^{47}$ but photography agencies with propensities for hiring émigré photographers had already been established in New York City. American picture agencies had begun to set up bureaus throughout Europe (including in Berlin) since the mid-1920s, and the resultant personal and professional networks between Germans and Americans were essential for new émigrés looking to relaunch their careers after landing in the United States. ${ }^{48}$ In 1935 , Leon Daniel and Celia Kutschuk, two former Associated Press Berlin picture editors, joined forces with photographers Alfred Eisenstaedt and Georg Karger to establish Pix Publishing. ${ }^{49}$ Much like the Black Star agency, Pix employed "a similar path [to the Black Star agency] of relying on a European or German émigré network," primarily selling its photographs to Life and Sports Illustrated. ${ }^{50}$ After arriving in New York, Leen immediately became

\footnotetext{
${ }^{46}$ Dalia Habib Linssen, "Imprints of Their Being: The Photographs of Hansel Mieth and Otto Hagel," (PhD Diss., Boston University, 2010), 31-32; Even creative expression was fated for repression: movements such as Dada, Bauhaus, Surrealism, and Expressionism, which Leen would have been exposed to while studying painting in Berlin, had been condemned by the Nazis since the 1920s. Markedly, the party's "Degenerate Art Exhibition" was held in 1937, just two years before Leen would depart for America.

${ }^{47}$ Claudia D. Goldin, "The Role of World War II in the Rise of Women's Employment," The American Economic Review 81, no. 4 (September 1991): 741.

${ }^{48}$ Estelle Blaschke, "Photography and the Commodification of Images: From the Bettman Archive to Corbis (ca. 1924-2010)" (PhD Diss., École des Dautes Études en Sciences Sociales, 2011), 114-115.

${ }^{49}$ Blaschke, "Photography and the Commodification of Images," 116.

${ }^{50}$ Ibid., 115-116
} 
aware of the accessibility and potential profitability of a career in photojournalism, and decided to take advantage of this opportunity by joining Pix.

Without Pix, Leen might never have appeared on Life's radar. According to C.

Zoë Smith, many émigré photographers in the United States stopped relying on agencies for work once their reputations had been established: "Pix Inc. lost Alfred Eisenstaedt, Nina Leen, Cornell Capa, George Karger, Erich Schaal and Albert Fenn to Life after providing the magazine with their work for a 'test period'." ${ }^{51}$ For Leen, as for others in her position, Pix was a means to an end. Once her reputation had been solidified, Life would come knocking. ${ }^{52}$ Her photographs made their first appearance in Life on April 1, 1940, whereas Leen's first Life credit that was not followed by the word 'Pix' was published in the magazine on May 7, 1945. Life utilized Leen's Pix photographs for just five years before deciding the magazine would be better off with her name on its roster.

Life's main competitor, Look, missed out on an opportunity to work with Leen shortly after her arrival in America:

An incident which Leen still recalls from her first few years in this country probably would have discouraged someone less committed to a career as a photojournalist: during lunch with a Look editor, Leen was advised to forget about her interest in photographers around New York and many of them were having trouble supporting their own families. Happily, she did not follow his advice. Instead, Leen went on to produce numerous essays on fashion, American manners and mores, and animals until the magazine ceased publication in the early 1970 s. $^{53}$

The suggestion that Leen ought to be concerned about supporting a family demonstrates the attitudes of Look's executives toward gender, as does the fact that the magazine

\footnotetext{
${ }^{51}$ Smith, "Émigré Photography in America," 126.

${ }^{52}$ Ibid., 127.

${ }^{53}$ The specific editor is not named. Smith, "Émigré Photography in America," 240.
} 
would hire only one long-term woman staff photographer during its thirty-four year run. ${ }^{54}$ Little did that editor know, Leen would never become a mother, and by 1954 Life would be paying her a salary of $\$ 18,000$ - the equivalent of approximately $\$ 166,000$ in 2018 according to the American Bureau of Labor Statistics. ${ }^{55}$ Her husband, Serge Balkin, was employed as a fashion photographer at Condé Nast, and with no children to support, their combined income would have allowed the couple to live comfortably for as long as they continued to work. No available documentation reveals how Leen reached the precarious financial situation in her old age that required her to hand over the rights to her photographs to Time Inc.

According to Smith, "the émigré picture agents, photographers, and editors who brought new practices to the United States were well-educated, well-traveled, intelligent men and women who had enjoyed considerable social status in Germany." 56 Leen was certainly worldly, having lived in Italy, Switzerland, and Germany after departing her native Russia. Her education provides yet another clue to her economic and social status, as Leen attended boarding school in Dresden before studying painting in Berlin - not the most infallible means of finding gainful employment. Leen would not have opted to study fine arts had she been deeply concerned with being able to support herself, which suggests her place in the middle-class. Her ability to sit down to lunch with an editor from Look so soon after arriving in America also indicates that Leen had prior connections to the press world in New York City. Though Leen's position was not

\footnotetext{
${ }^{54}$ Chloe Coleman, "This Photographer who Documented Professional Pioneers was a Pioneer Herself," Washington Post, October 21, 2016, https://www.washingtonpost.com/news/in-sight/wp/2016/10/21/thisphotographer-who-documented-professional-pioneers-was-a-pioneer-herself/?utm_term=.d03c312501b9. ${ }^{55}$ Ray Mackland, "Ray Mackland to Bob Elfson," letter, from New-York Historical Society, The Time Inc. Archives, 1954, accessed February 1, 2018.

${ }^{56}$ Smith, "Émigré Photography in America," 6.
} 
characteristic of the typical 1940s woman, nor of the average World War II refugee, the narrative of her journey is analogous of other European-born photojournalists living in America at the time.

Following the country's widespread post-war return to traditional values and gender roles, many women previously working in industrial jobs were replaced by men returning home from war. ${ }^{57}$ Even Life stopped hiring women as staff photographers after 1951. Bourke-White was technically the last woman to receive a staff contract, on January 1, 1951, after working under an all-rights contract since October 1, 1936. Other women would be hired to create photographs for Life over the next two decades, but not as staff photographers. Elaine Tyler May hails this newfound attitude of the 1950s as “domestic containment," with home, marriage, and parenthood acting as a safeguard, thereby answering “Americans' intense need to feel liberated from the past and secure in the future." ${ }^{58}$ For women who did work outside the home, many found themselves in substandard, pink-collar roles or gendered occupations such as nursing and teaching. Even with the help of her education and connectedness with the publishing world, Leen's gender meant that she found her way into Life during a narrow window of opportunity.

Former Life writer and editor Loudon Wainwright Jr. offers insight as to Leen's standing, compared to the magazine's other photographers. The staff photographers, he writes, were

an especially impressive crowd, including not only such already famous names as Alfred Eisenstaedt and Peter Stackpole, Dmitri Kessel and Gene Smith, but also many less celebrated but first-class photojournalists - Cornell Capa (Robert's

\footnotetext{
${ }^{57}$ Maria Cristina Santana, "From Empowerment to Domesticity: The Case of Rosie the Riveter and the WWII Campaign," Frontiers in Sociology 1, no. 16 (December 2016): 5.

${ }^{58}$ Elaine Tyler May, "Introduction," in Homeward Bound: American Families in the Cold War Era, (New York: Basic Books, 2008), 12.
} 
younger brother), Mark Kauffman, Bernard Hoffman, Nina Leen, Fritz Goro, Wallace Kirkland, Walter Sanders. ${ }^{59}$

Numerous photographers who fall into the latter, 'less celebrated' group with Leen have yet to receive scholarly attention, including those mentioned by Wainwright plus others such as Grey Villet, Martha Holmes, and Lisa Larsen. The five other women hired by Life as staff photographers before 1951 were Margaret Bourke-White, Marie Hansen, Martha Holmes, Hansel Mieth, and Lisa Larsen, although none of these photographers found themselves at Life by way of photographic agencies. Other notable Life photographers, including Alfred Eisenstaedt and Fritz Goro, followed similar trajectories to Leen's: from emigration to agency and eventually to contracts with the magazine. ${ }^{60}$

Leen's Pix photographs were published in sixty-five stories throughout fiftyseven issues of Life between April 1, 1940 and May 7, 1945. During this period she created three photographic essays: "The World of Washington Irving" and "Teen-Age Girls" in 1944 (Figure 2), and "Sub-Deb Clubs" in 1945. In 1937, Life introduced readers to the concept of the photographic essay in a story called "The Camera as Essayist," which read, "The camera is not merely a reporter. It can also be a commentator. It can interpret as it presents." ${ }^{61}$ According to C. Zoë Smith, the photographic essay's attempt to exhibit "a deeper, more complex understanding of a person, place, or event" ${ }^{\text {"62 }}$ was already integral to German illustrated magazines before being employed by Life. In addition to their subjective leanings and more exhaustive treatments of given topics,

\footnotetext{
${ }^{59}$ Loudon Wainwright, The Great American Magazine: An Inside History of Life (New York City: Knopf, 1986), 169.

${ }^{60}$ Smith, "Émigré Photography in America," 117.

61 "The Camera as Essayist," Life, April 26, 1937, 62-63.

${ }^{62}$ Smith, "Émigré Photography in America," 5
} 
photographic essays were characteristically longer than regular stories in Life, the latter covering an average of three pages, yet occasionally spanning up to thirteen. Image size fluctuated as well, with photographs blown up to cover entire pages or shrunk to fit among others, although this variation can also be discerned in other stories (Figure 3).
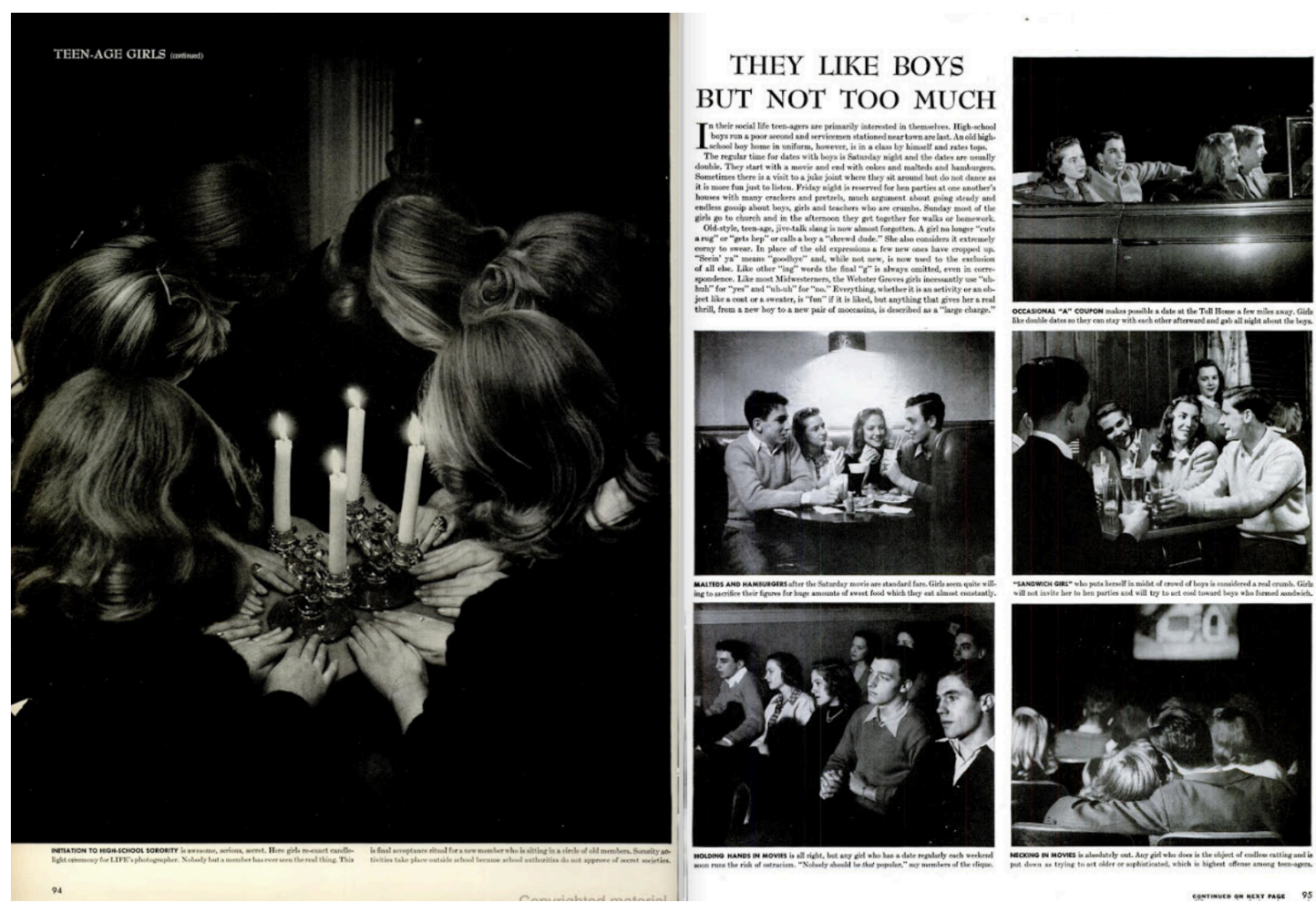

Figure 2: Nina Leen, “Teen-Age Girls,” Life, December 11, 1944, 94-95.

In addition to three photographic essays, Leen created or contributed to twentytwo stories about fashion, seven on animals, and fifteen stories concerning children, youth, and women, in what C. Zoë Smith interprets as an apprenticeship period commonly experienced by agency photographers. According to Smith, "many émigrés proved during their 'apprenticeship' at Black Star they had the qualities of a good magazine photographer: physical stamina, versatility, technical expertise, journalistic 
skill in handling story ideas, and the ability to deal with people. ${ }^{, 63}$ Considering that Leen began working for Pix with no prior knowledge of the mechanics of photography, not only did her apprenticeship lead to a newfound mastery of the camera, but her newfound aptitude was sufficiently well developed to convince Life's executives to hire her.

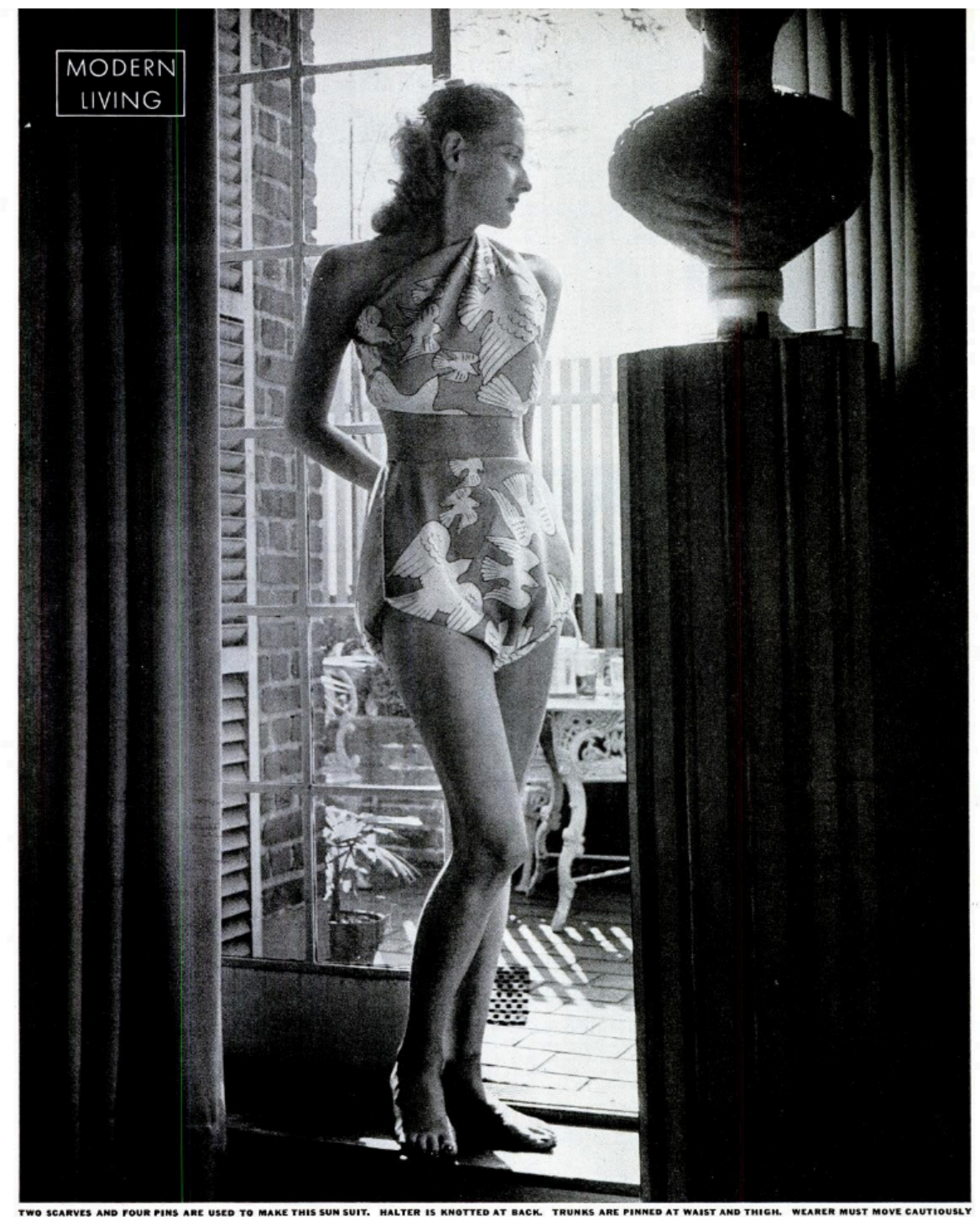

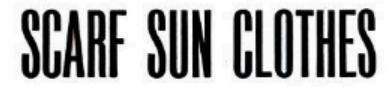

They are good for lounging but not practical for active sports
U. S. women this summer have discovered that a ed or ingeniously pinned, it becomes a pair of shorts
or a halter (see abore), skirt, sarong, belt, turhan or or a halter (see abore), skirt, sarong, belt, turban or
bra (see nest page). Limitations on dress trimmings bra (see ned prager). Limitations on dress trimmings
and scarcity of bright new-looking play elothes have prompted women to make the most of a scarfs mong prompted women to make the most of a scarrs many a new high, have increased another $37 \%$ this yen.

Scart elothes are most useful for lounging or group -batting. They are not practical for active sports or for going in the water. For skirts, scarf addicts they should we hares at least 35 wide. For brac type or squares folded on the bias. For sarone or shorts, they should use heavy ones about one yant square, tic all knots tightly and, when wearing their creations, practice the utmost restraint in movement.

Figure 3: Nina Leen, "Scarf Sun Clothes," Life, July 7, 1944, 65.

${ }^{63}$ Ibid., 125. 
Leen quickly showcased her versatility, affability, and storytelling skills in an attempt to impress Life's editors, proving her competency in these areas through a diversity of assignments and genres. On April 20, 1942, Leen illustrated her qualifications through two fashion stories, printed back-to-back in the 'Modern Living' section of the magazine. "Slacks," a two-page cover story informing readers that slacks were the latest trend in women's fashion, was directly followed by another two-page segment entitled "Women Lose Pockets and Frills to Save Fabrics," which outlined the War Production Board's latest regulations on women's clothing.

Leen contributed four out of the ten photographs printed on the first page of "Slacks," while Johnny Florea and K. Chester are credited with creating the remaining six. The story continues with one photograph covering half a page on each of the next three spreads, all by Leen. In these two stories, the category of photojournalism is extended to include fashion photography, and fashion photography also comes in a variety of forms. The photographs on the first page of "Slacks" show women out in the streets, going about their daily business while wearing pants (Figure 4). The final three images in "Slacks," as well as every photograph in "Women Lose Pockets and Frills to Save Fabrics," were created in a studio setting (Figure 5). 


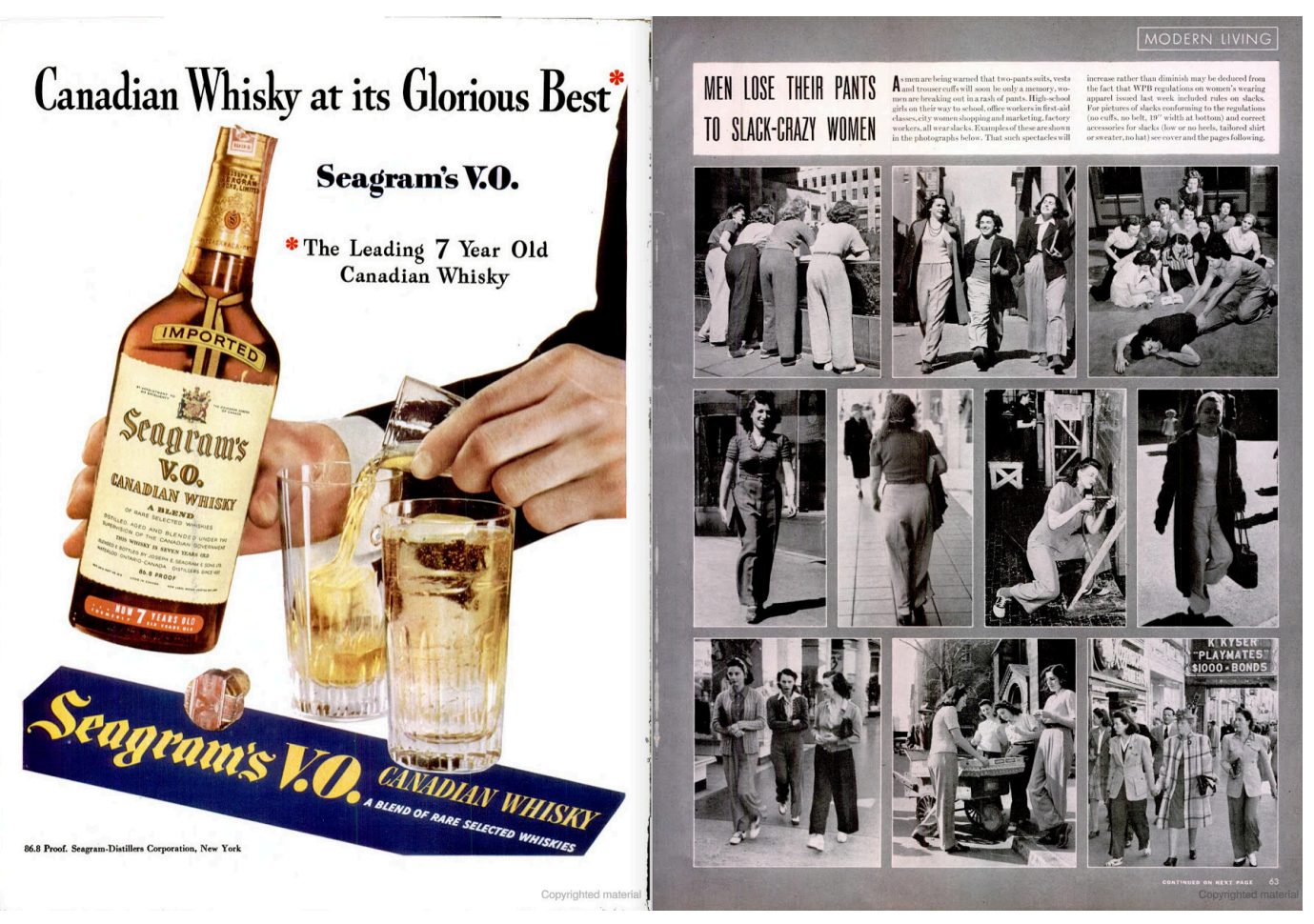

Figure 4: "Slacks," Life, April 20, 1942, 62-63.
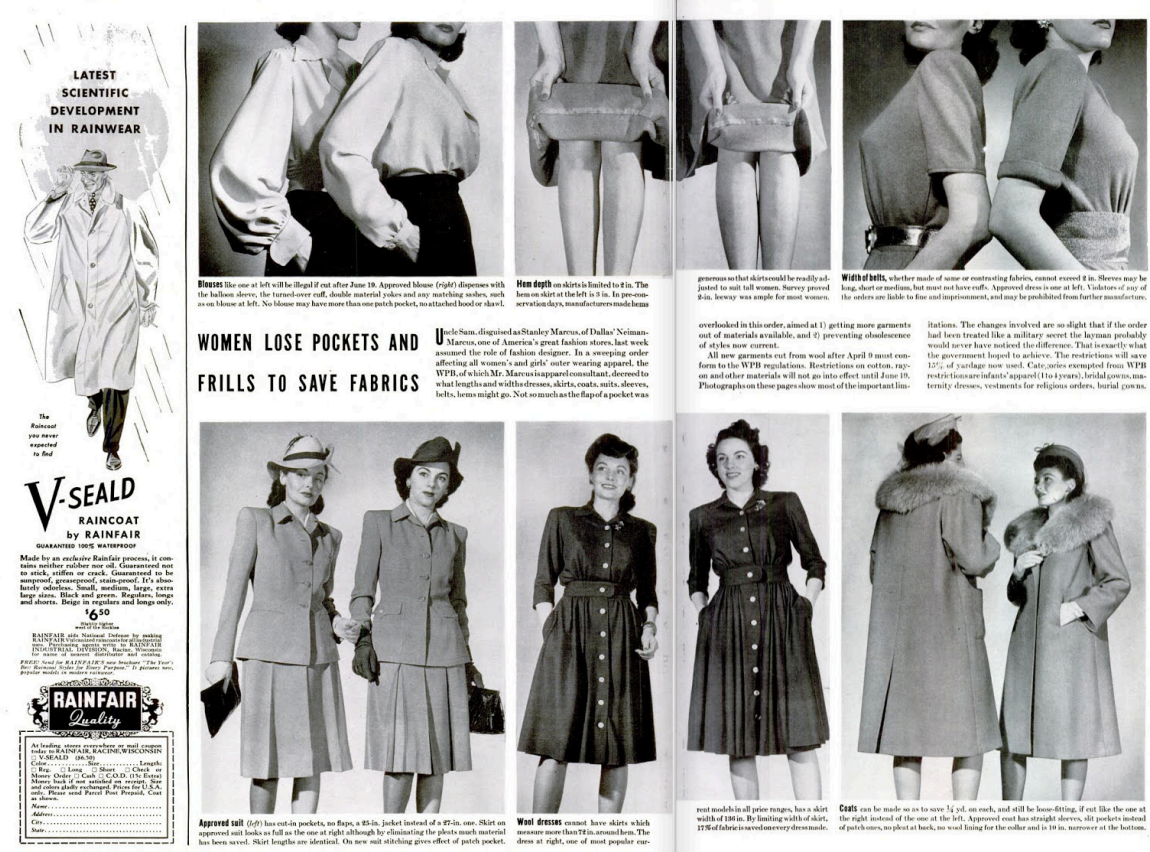

WOMEN LOSE POCKETS AND

FRILIS IO SAVE FABRICS
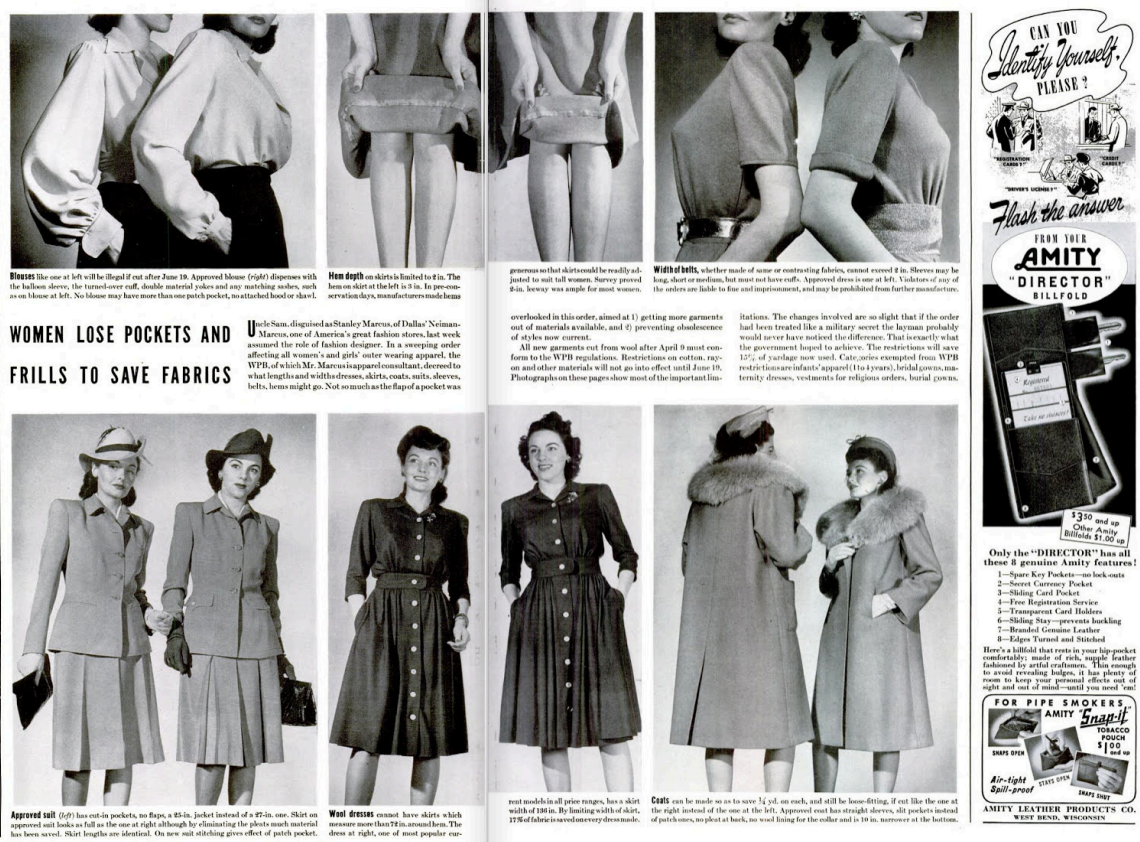

Figure 5: "Women Lose Pockets and Frills to Save Fabrics," Life, April 20, 1942, 70-71. 
A closer look at Leen's contribution to the "Slacks" story reveals her habitual method of shooting fashion photography. The three photographs along the top row and the image in the centre of the bottom row, which are credited to Leen in the table of contents, appear more posed than those by Florea and Chester. Images by Leen showing carefully arranged models appear on five of the following eight pages, both in this story and the next, with the remaining three pages dedicated to advertisements. The negatives created for "Slacks" also reveal Leen's tendency to pose her subjects. A cycling model, for example, is photographed in a variety of poses and framed by various background details, including the Washington Square Arch (Figures 6-8). According to Leen, it was "better to pose a good picture than to have an unposed bad one," ${ }^{64}$ whether in a studio not.

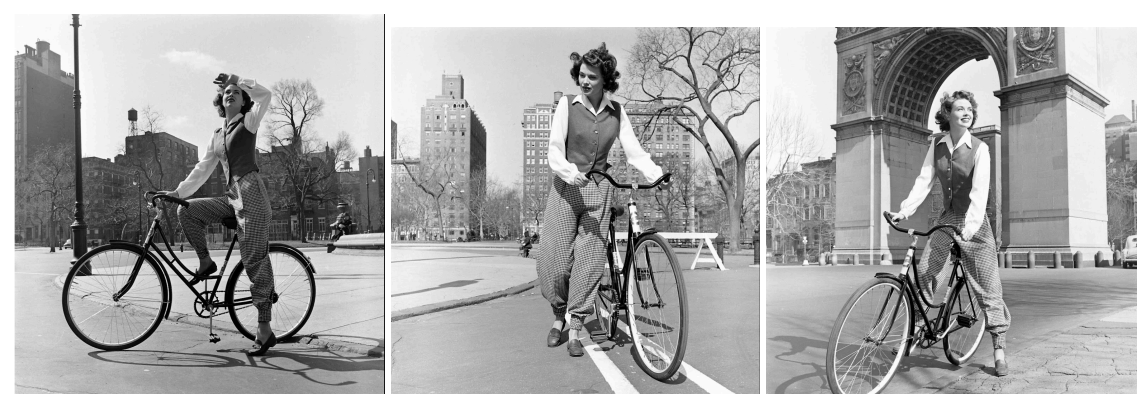

Figures 6-8: Nina Leen, "Slacks," digital reproduction from black and white negatives, April 1942. Life Photo Collection, Google Arts and Culture.

By 1942, the magazine's editors were relying on Leen's work to provide it with photographs showcasing an assortment of points of view. These two back-to-back stories showcase Leen's versatility - she thrived in both artificial and natural settings. They also demonstrate Life's reliance on Leen to create photographs that would complement, rather than duplicate, the heroic and newsworthy photographs shot by her coworkers. After having proven herself to Life through her Pix photographs, she was offered a job at the magazine the very year that World War II came to a close.

\footnotetext{
${ }^{64}$ The Editors of Life, "Nina Leen," 240.
} 


\section{Staff Days, Soft Stories}

In his prospectus for Life, Luce noted, "cameramen who use their heads as well as their legs are rare. ${ }^{95}$ Any photographer entrusted to create content for his magazine would logically be held to high standards, and Nina Leen was no exception. For a magazine that would hire only 101 staff photographers over thirty-six years ${ }^{66}$ being selected to join this cohort was more than a mere honour: "The reputation Life had helped it become 'the' place for a magazine photographer to be published in the 1940s and 1950s. ${ }^{967}$ Of these 101 photographers, Leen and ten others had exceptional relationships with Life, being considered staff, or on par with staff though technically their contracts differed from those of official staff photographers. Leen, for example, worked under an all-rights contract, which primarily differed from a staff contract by allowing her to work for other publications. What makes this all the more impressive is the fact that, of these 101 photographers, only six were women.

In her first five years after leaving Pix for a contract with Life, Leen's photographs were published in 105 issues. By the close of 1954, her tenth year as an official Life photographer and fifteenth year publishing photographs in the magazine, Leen's work had been featured in 255 issues. In that year alone her photographs were used in seventeen issues, or between one and two issues per month. Not only did Leen hold an enviable position at America's foremost pictorial magazine, she was also prolific. Leen's productivity was a consequence of her efficiency, with her fashion and lifestyle

\footnotetext{
${ }^{65}$ Henry Luce, “A Prospectus for a New Magazine," 1936.

${ }^{66}$ John Loengard, "The Ambition Behind This Book," in The Great Life Photographers, ed. John Loengard and Gordon Parks (New York: Time Warner Book Group, 2004), 6-11.

${ }^{67}$ Smith, "Émigré Photography in America," 178.
} 
stories requiring less engagement and stylistic nuance than the elaborate photographic essays of W. Eugene Smith.

Leen published more 'Modern Living' stories in 1945 than any other year, and in 1950 she published eleven stories in Life's Fashion section, the greatest quantity of work she would ever produce for the department in a single year. "Summer Beach Fashions," published in the 'Fashion' department on May 15, 1950, was one of them. The story covered seven pages, with an additional image from the story printed on the cover of the issue. Leen's photographs dominate the first three spreads, in which few advertisements and little text accompany her images. The first spread features a black and white photograph of four women wearing straw hats on a beach, three of whom are facing away from the camera. Two short paragraphs of text sit below the title of the story, taking up less than half of the page. A single colour image comprises the right side of the spread, depicting a woman wearing a pink cape and a straw hat adorned with flowers, again facing away from the camera. The subject stands on a concrete staircase with her legs positioned shoulder-width apart, her left hand resting in the pocket of her terry cloth toga and her right hand out of view. While the models are crucial to both of these photographs, Leen decided to photograph them from behind in order to foreground their attire.

The second spread features two photographs, again one printed in colour and one in black and white (Figure 9). These images take up the majority of each page, with only two lines of text below each photograph. The colour image on the left depicts a woman in striped Capri pants sitting on a boardwalk, letting sand fall from her fist, while the black and white photograph on the right features three women wearing stripes, two sitting and one lying in the sand, with a striped umbrella behind them. In the latter, the women are 
composed in a compact triangular formation, with the umbrella behind them further limiting the photograph's depth of field; the repetition of four slightly dissimilar striped patterns is commanding and whimsical. By tightening the frame around the models and their umbrella, Leen's photograph forces the reader's eye to focus on the true subject of the story - the striped beachwear.

The third spread features a single black and white photograph of four women lying in the sand. A pair of sandals and a straw hat sit directly in the middle of the image, which covers the entire left page and bleeds onto the right. The right-hand page is divided in half vertically, and the remaining space is filled with a colour advertisement for Hi-C Orangeade (Figure 10). The photograph is taken from above, and the text below describes the bathing suits, including their respective designers and prices. Although a similar composition could have been achieved by having the models stand upright, the women appear natural and informal, relaxing on the sandy beach. Leen altered her own vantage point to create a birds-eye-view image, foregrounding the swimsuits by encompassing the entirety of the models' bodies, and showing the women in a position commonly assumed on the beach. Life's readers are invited to look down on the models, who in their sprawled positions appear more relatable than statuesque, making the clothing seem all the more attainable.

In order to create this photograph Leen also experimented with fine-tuning. Examining her negatives from this shoot reveals that she altered the placement of models and props ever so slightly - the model on the right even changed swimsuits in between shots - while keeping their overall configuration consistent (Figures 11-12). The published image is extremely similar to Leen's negatives, indicating that this photograph 
required no significant editing. By presenting Life's editors with numerous variations of the same image, they could focus their attention on selection rather than cropping, lightening, darkening, or other editing.

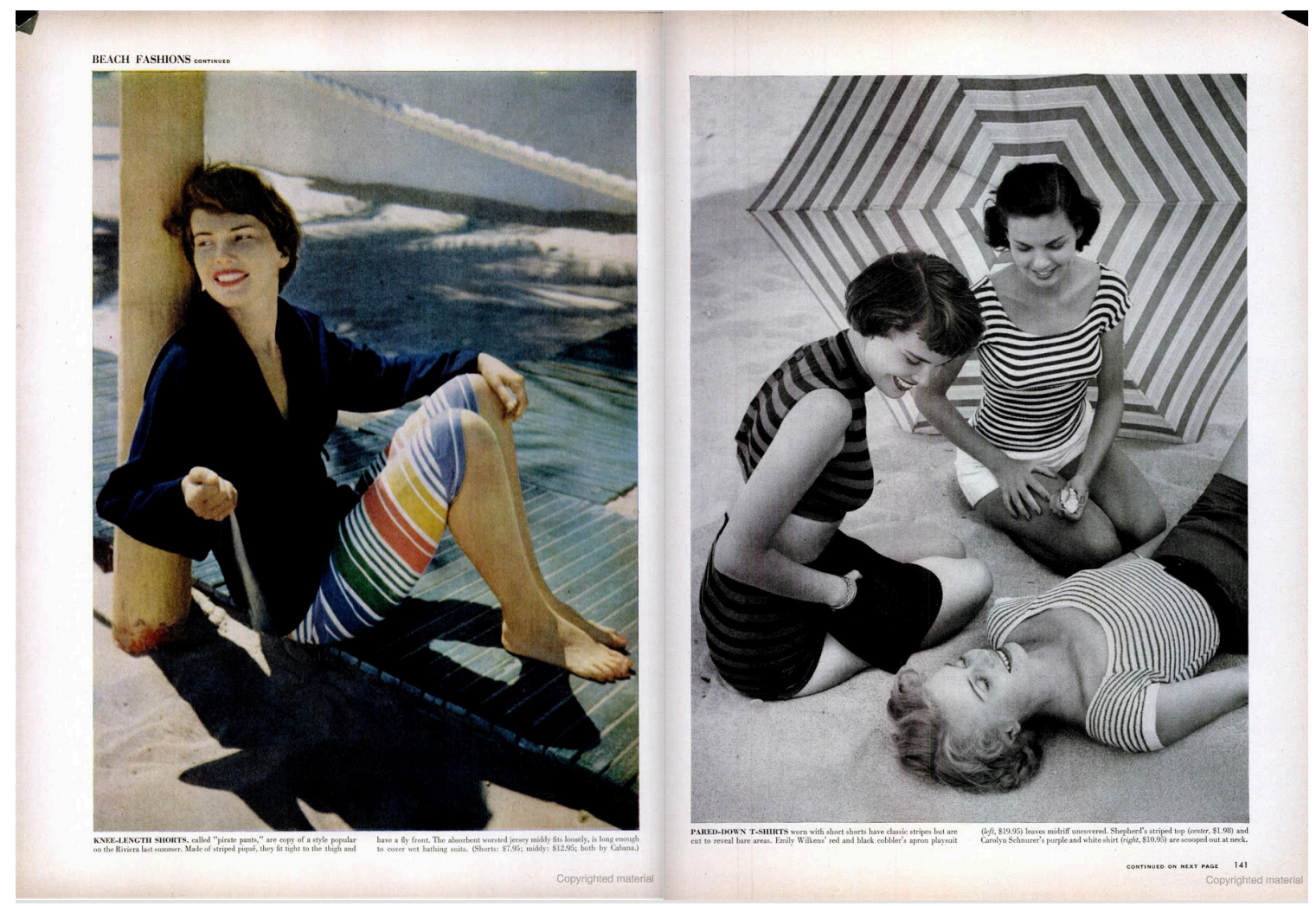

Figure 9: Nina Leen, “Summer Beach Fashions,” Life, May 15, 1950, 140-141. 

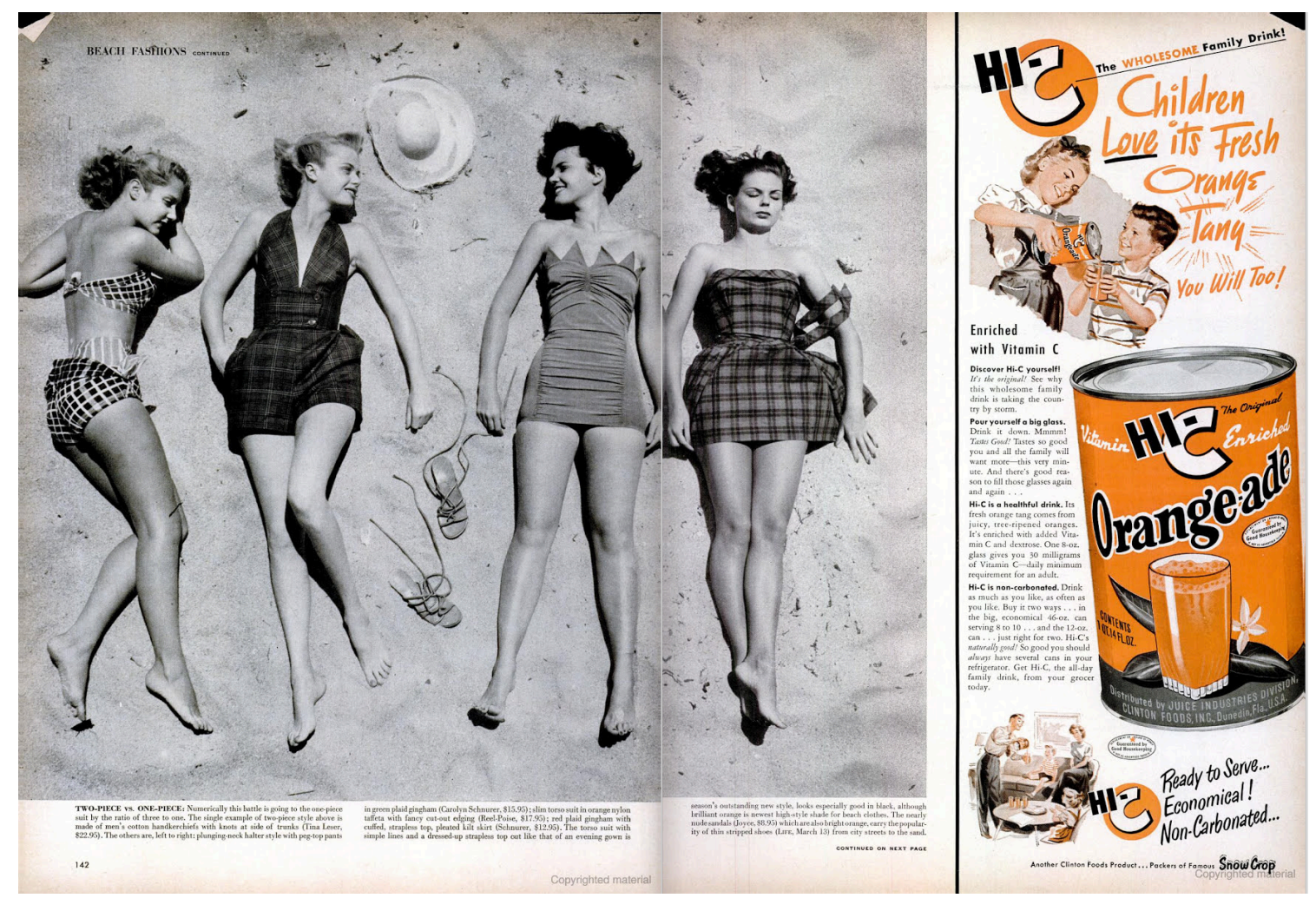

Figure 10: Nina Leen, “Summer Beach Fashions,” Life, May 15, 1950, 142-143.

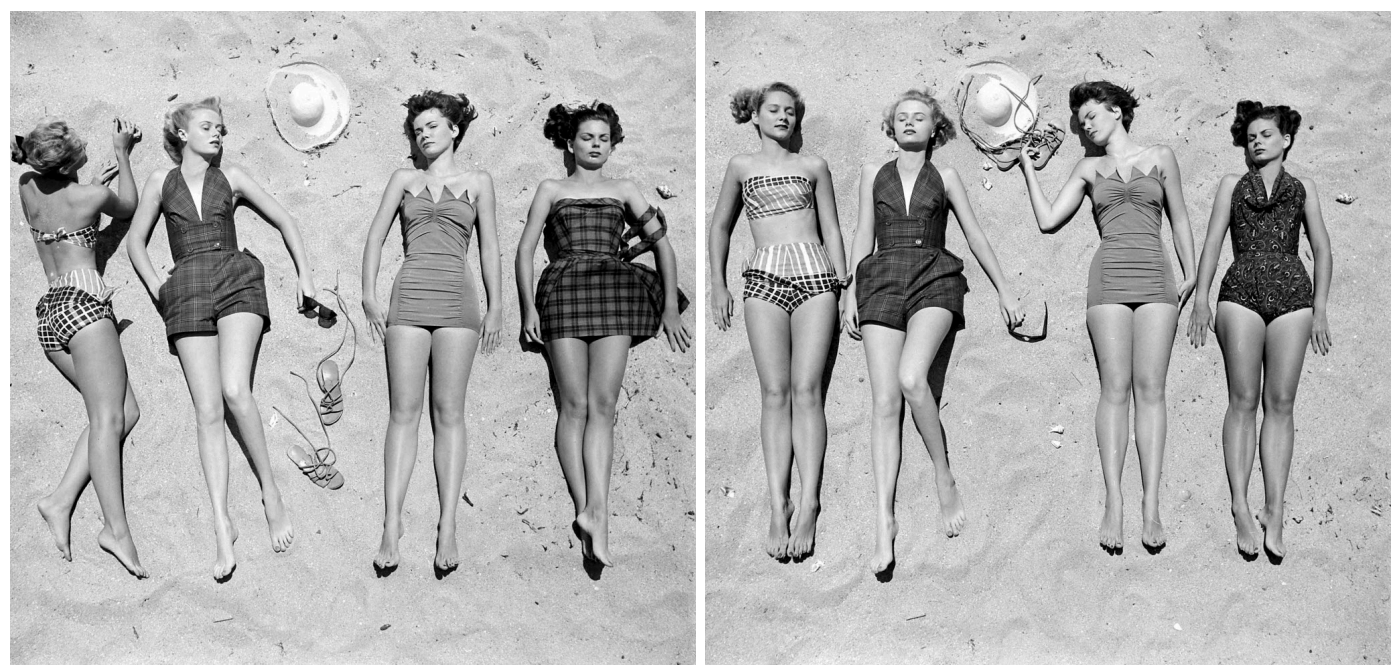

Figures 11-12: Nina Leen, "Summer Beach Fashions," digital reproduction from black and white negatives, May 1950. Life Photo Collection, Google Arts and Culture.

On the final spread of "Summer Beach Fashions" (Figure 13), four miniscule photographs are crammed into half of a single page. The other half features an 
advertisement for Shasta Beauty Cream Shampoo, while the next page is entirely dedicated to an advertisement for Scot Tissue. A hierarchy exists even within Leen's own story: whereas the first five photographs in the first three spreads take precedence over ancillary content, the final four images on the last page become lost amidst advertisements and text. The first five images are large, eye-catching and jovial, while the final four are simplistic, illustrative images of items of clothing available for purchase by readers. Life's editors required arresting and amusing images, but they also needed supplementary photographs to fill the pages of the magazine, and Nina Leen supplied them with both.
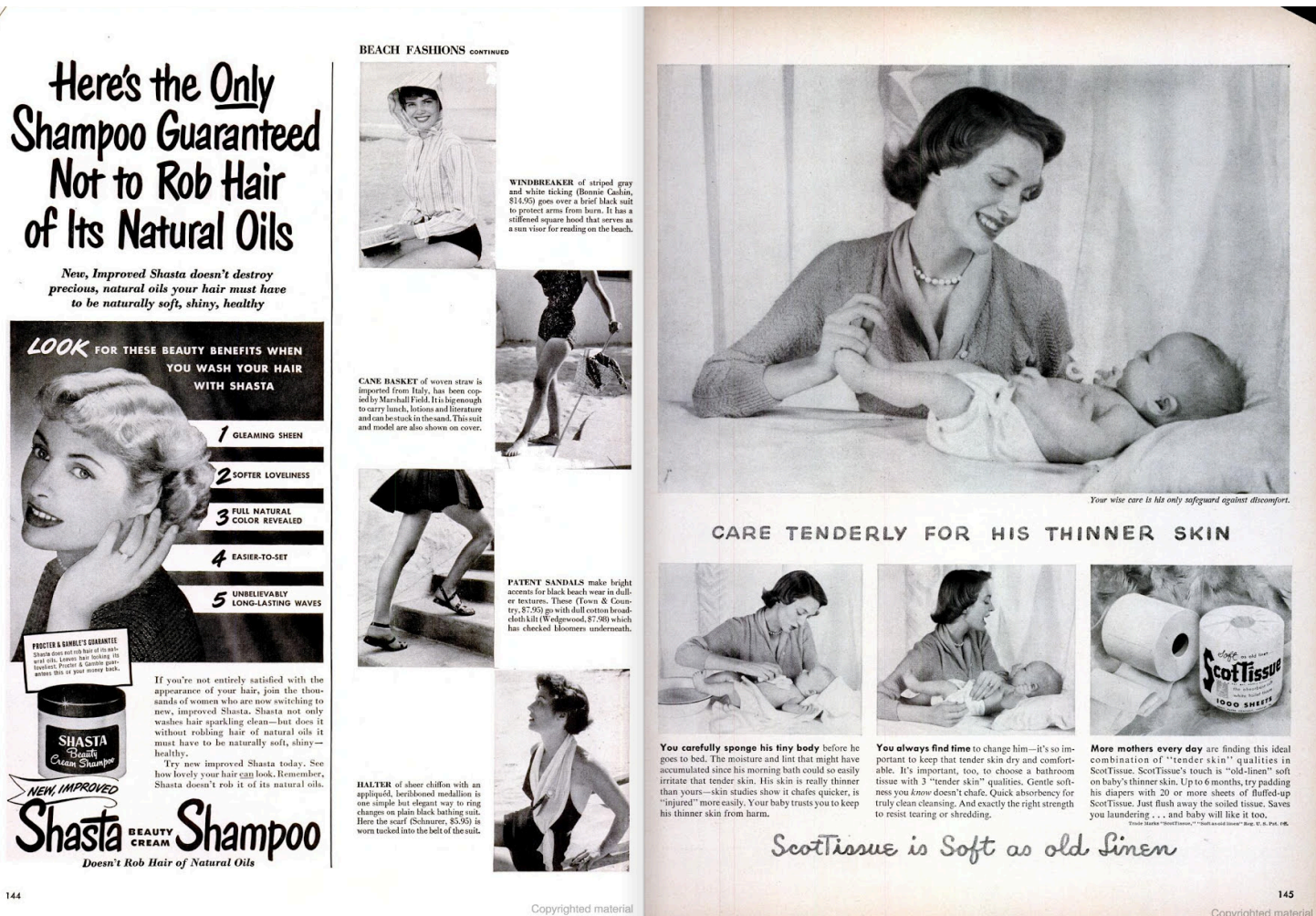

Figure 13: Nina Leen, “Summer Beach Fashions,” Life, May 15, 1950, 144-145. 
According to Roland Barthes, the name of a newspaper or magazine "represents a knowledge that can heavily orientate the reading of the message strictly speaking." 68 What sort of orientation, then, is fashioned by a name such as Life? While Life's celebrity photojournalists such as Margaret Bourke-White, Robert Capa, and W. Eugene Smith are remembered for their photographs of serious subjects and events - war, industry, affliction, et cetera-Life is about more than just that. Executives at the magazine were wholly aware of this fact: Luce himself "did not want Life to get excessively serious," calling for "more charming pictures, more boy-and-girl, more fun" at a conference in 1939.69

Leen supplied thirty issues of Life with photographs printed in the 'News' section, making up approximately eight percent of her total work for the magazine. Hard news photographs taken by Leen concerning war, politics, and economics appear in the magazine just thirty-two times. Leen preferred this smaller news-to-non-news ratio, disliking photographing the news "particularly because you have to fight . . . you have to ... have good elbows to get your picture."70 The remainder of her assignments were soft news stories - entertainment, fashion, lifestyle, and the arts - and this specialty worked to establish and sustain her reputation at the magazine.

Entertaining content was as vital to Life's success as pictorial reportage of newsworthy events. In his discussion of Life's circulation and readership, James L. Baughman emphasizes that "while attending to news, Life never tried to be Time. Life

\footnotetext{
${ }^{68}$ Barthes, “The Photographic Message," Image, Music, Text, trans., Stephen Heath (London: Fontana Press, 1977), 15.

${ }^{69}$ James L. Baughman, Henry Luce and the Rise of the American News Media (Baltimore: Johns Hopkins University Press, 2001), 99.

70 "Unchecked and Uncorrected Transcript of Interview with Nina Leen" by John Loengard, interview, New-York Historical Society, The Time Inc. Archives, January 14, 1992, accessed February 1, $2018,16$.
} 
was much more fun.. ${ }^{, 71}$ Loudon Wainwright concurs in his summary of the magazine's

contents, which included

trivial and vulgar fragments about starlets and hairstyles nestled among splendid color portfolios about the glories of antiquity, titillating items about the weird habits of quirky socialites followed high-minded entreaties for American greatness, powerfully moving black-and-white picture essays illustrating the joys of childhood abutted shocking photographs of starvation victims and of people leaping to their deaths from burning buildings. ${ }^{72}$

Leen's colleague Lisa Larsen occasionally photographed news stories, which Leen noticed was unusual for women: "Now when she was on a news assignment, there were mostly men. Very few woman, on news pictures." "73 According to a 2015 study published by the World Press Photo Foundation, women photojournalists were "less focused on news photography than their male counterparts," 74 revealing that this propensity for women to photograph soft news has endured well into the twenty-first century. Although photographing the myriad of soft subjects that made up a large portion of Life's photographic content was not necessarily indicative of a photographer's status at the time, this unserious, non-news content has long been associated with femaleness.

Ironically, Leen's two most reproduced and well-recognized photographs do not reflect the nature of the majority of her assignments for Life. The first photograph depicts four generations of the Russells, an Ozark farming family (Figure 14). The group is huddled close together around a wood-burning fireplace, with the ninety-year-old matriarch in the centre in a rocking chair, and paintings of deceased members of the family hanging on the wall behind them. The photograph was originally published on the

\footnotetext{
${ }^{71}$ Baughman, "Who Read Life?," 46.

${ }^{72}$ Wainwright, The Great American Magazine, xv.

73 "Unchecked and Uncorrected Transcript of Interview with Nina Leen" by John Loengard, interview, New-York Historical Society, The Time Inc. Archives, January 14, 1992, 3.

${ }^{74}$ Adrian Hadland, David Campbell, and Paul Lambert, The State of News Photography: The Lives and Livelihoods of Photojournalists in the Digital Age (Amsterdam: World Press Photo, 2015), 55.
} 
third page of a July 26, 1948 photographic essay entitled "The American Family in Trouble" (Figure 15).

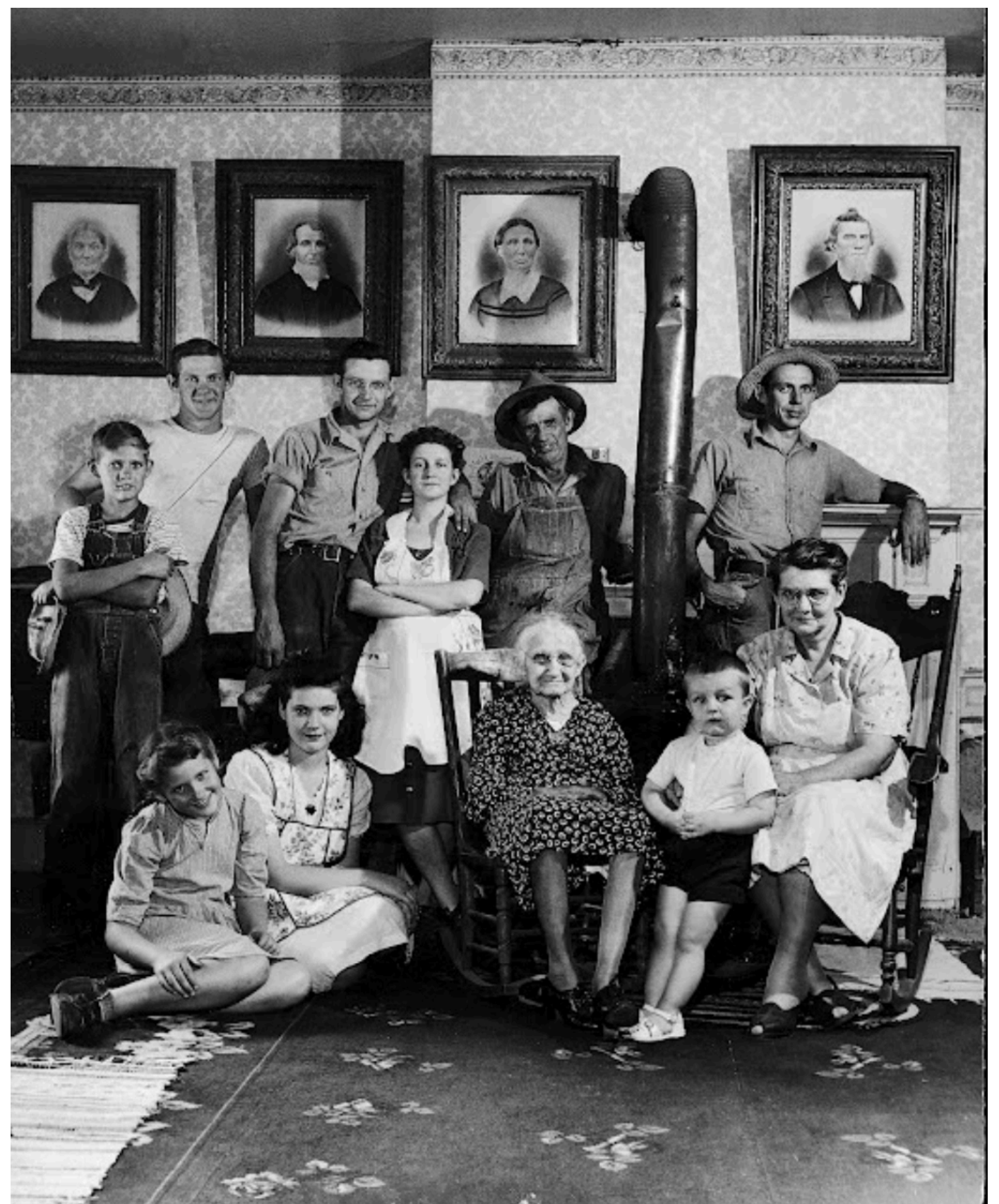

Figure 14: Nina Leen, "Four Generations of an Ozark Farming Family," digital reproduction from black and white transmission, July 1948. Life Photo Collection, Google Arts and Culture.

The essay expressed concern about increasing divorce rates in America, which

Life blamed on the sociological changes in families catalyzed by industrialization. 
Families moved from the classification of 'trustee' to 'domestic' and finally 'atomistic', discarding traditional values along the way ${ }^{75}$ The text accompanying Leen's portrait of the Russells, the model of the 'trustee' family, explains how even the most old-fashioned of American families are being forced to adapt to cultural and technological changes.

"The American Family in Trouble" covers nine spreads, and Leen created every photograph other than two small illustrative headshots of the two leading sociologists consulted for the story, which were purchased from the Associated Press. While Leen's photographs for the story are as carefully arranged as her fashion photographs, the subject matter represents a considerable departure.
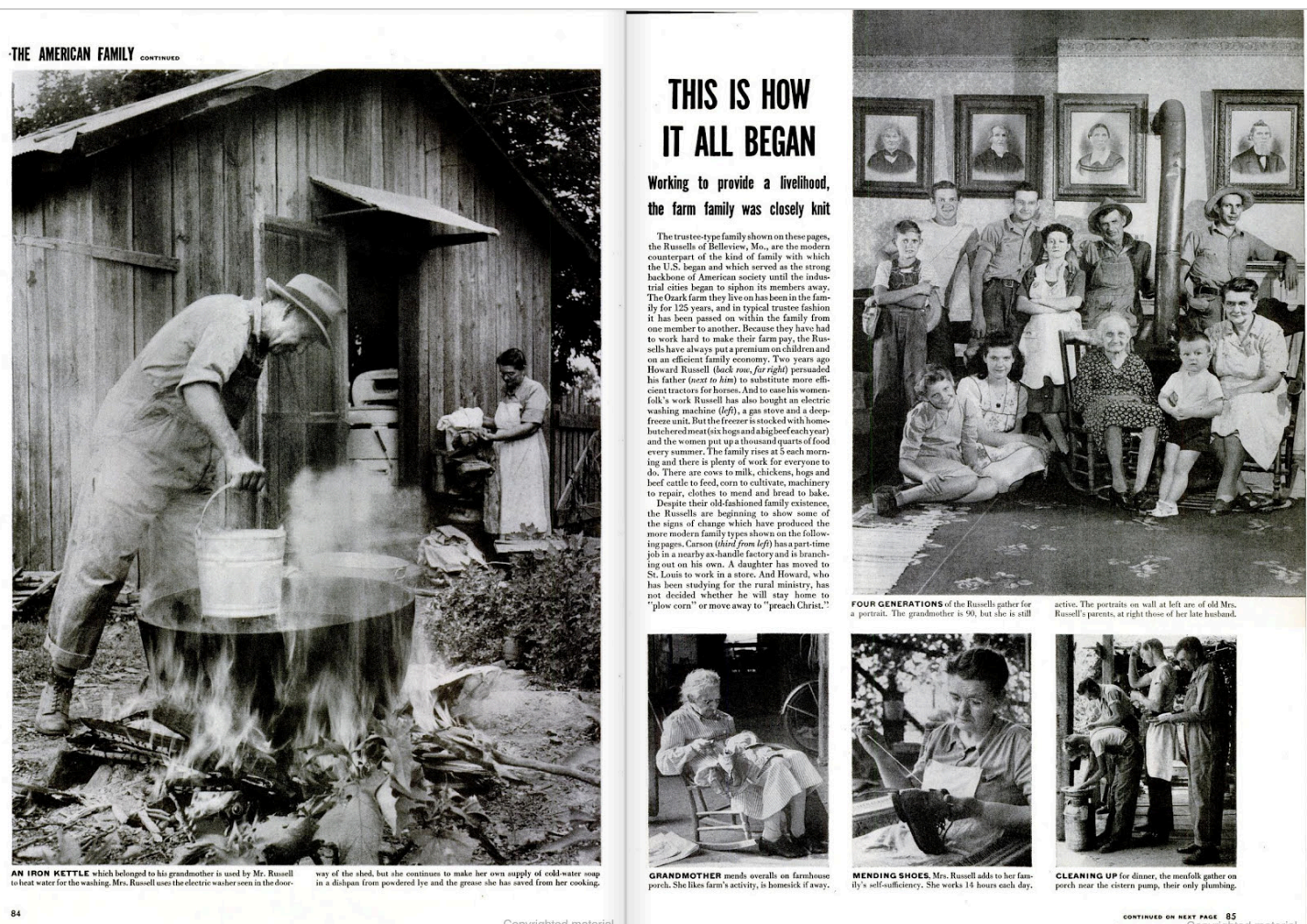

Figure 15: Nina Leen, “The American Family in Trouble,” Life, July 26, 1948, 84-85.

Unlike the bulk of Leen's Life photographs, "Four Generations of an Ozark

Farming Family" has been widely reproduced and exhibited. The photograph appeared

${ }^{75}$ Life, July 26, 1948, 83. 
"enlarged, double-sided, and duplicated" in "the centerpiece" of Edward Steichen's illustrious 1955 The Family of Man exhibit at the Museum of Modern Art (Figure 16). ${ }^{76}$ The Family of Man was an exhibition that aimed to depict, photographically, "the universal elements and emotions and the oneness of human beings throughout the world." 77 The work of over 200 photographers was exhibited, including Leen's Life contemporaries Margaret Bourke-White, Robert Capa, Dmitri Kessel, Lisa Larsen, and Alfred Eisenstaedt.

"Four Generations of an Ozark Farming Family" was also used to illustrate the entry for "Family" in Funk and Wagnalls Standard Reference Encyclopedia in $1969,{ }^{78}$ and astronomer Carl Sagan assigned his assistant Wendy Gradison and space artist Jon Lomberg to select the photographs for inclusion in NASA's Voyager Golden Record ${ }^{79}$ a compilation of images, music, sounds, and greetings "intended to communicate a story of our world to extraterrestrials," and launched into space aboard the two Voyager spacecrafts in $1977 .{ }^{80}$ Gradison and Lomberg selected images depicting everyday human activities, such as studying, shopping, building homes, fishing, eating, and breastfeeding, as well as photographs of landscapes architecture, and infrastructure. ${ }^{81}$ This singular image was selected from Leen's large quantity of photographs depicting fashion and lifestyle trends, isolated and venerated for its documentary-style gravity by the Voyager

\footnotetext{
${ }^{76}$ Gerd Hurm, Anke Reitz, and Shamoon Zamir, ed. The Family of Man Revisited: Photography in a Global Age (London: I.B. Tauris \& Co. Ltd, 2018), 167-168.

${ }^{77}$ The Museum of Modern Art, "Museum of Modern Art Plans International Photography Exhibition," press release, January 31, 1954.

${ }^{78}$ Joseph Laffan Morse, Funk and Wagnalls Standard Reference Encyclopedia, 1969 ed., s.v. "Family" (New York: Standard Reference Library, 1969), 3396-3397.

${ }^{79}$ Trevor Paglen, "Friends of Space, How Are You All? Have You Eaten Yet? Or, Why Talk to Aliens Even if We Can't," in Afterall: A Journal of Art, Context, \& Enquiry 32, no. 1 (Spring 2013): 12.

80 “The Golden Record,” Voyager, NASA, accessed April 20, 2018, https://voyager.jpl.nasa.gov/goldenrecord/.

81 “Images on the Golden Record," Voyager, NASA, Accessed April 20, 2018.

https://voyager.jpl.nasa.gov/galleries/images-on-the-golden-record/.
} 
team, Steichen, and the editors of Funk and Wagnalls Standard Reference Encyclopedia.

The choice to reproduce this photograph rather than one more characteristic of the maker's oeuvre reflects the interests of cultural arbiters, whose decisions also impact the work of historians. It also reveals the goals of professionals working to legitimate the field of photojournalism by placing socially engaged images on a pedestal, inevitably shrouding the multitudes of middlebrow images that served to fill a considerable proportion of the magazine's pages.

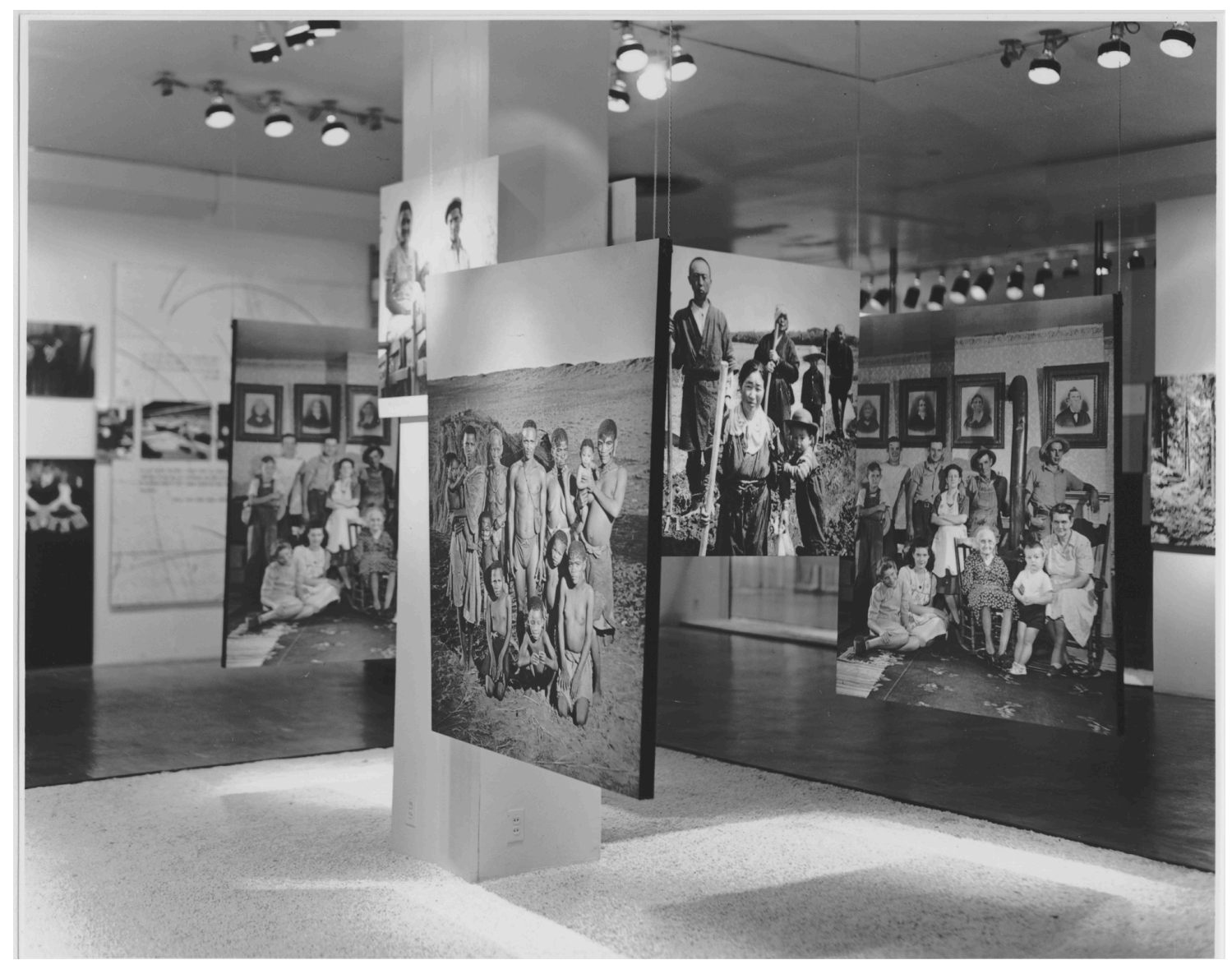

Figure 16: "Installation view of the exhibition The Family of Man," January 24, 1955-May 8, 1955. Photographic Archive. The Museum of Modern Art Archives, New York. IN569.48. Photograph by Rolf Petersen.

Grey Villet (1927-2000) was yet another Life photographer remembered best for a single set of images he created, rather than his entire oeuvre. Villet's work was published in 259 issues of Life between 1954 and 1972. Like Leen, his contribution to a 
particular issue of Life ranged from single illustrations to lengthy photographic essays.

He covered everything from sports and celebrities to politics and religion, and his photographs often appeared in 'The Week's Events', Life's dedicated news section. Villet's most iconic photographs were published in "The Crime of Being Married," published on March 18, 1966 (Figure 17). The photographic essay follows Mildred and Richard Loving, an interracial couple who, after being arrested five weeks after their wedding for violating Virginia's anti-miscegenation law, appealed the decision to the US Supreme Court and won. ${ }^{82}$ Villet's photographs of the Lovings gained contemporary recognition in 2012 during director Nancy Buirski's production of her film The Loving Story. ${ }^{83}$ Buirski's rediscovery of Villet's work resulted in a 2012 exhibition of his photographs of the Lovings held at the International Centre of Photography, and subsequently put on view at Photo L.A. and made available for purchase by the Monroe Gallery in $2017 .{ }^{84} \mathrm{~A}$ fraction of Villet's photographs have received recent recognition from both the art market and the cultural heritage sector, though the remainder of his work, much like Leen's, has yet to be studied.

\footnotetext{
82 "The Crime of Being Married," Life, March 18, 1966, 85-91.

83 “The Loving Story," International Center of Photography, 2012, accessed May 18, 2018, https://www.icp.org/exhibitions/the-loving-story-photographs-by-grey-villet.

${ }^{84}$ Craig Nakano, "1960s Life magazine photos of the 'Loving' couple, on view at Photo L.A.," L.A. Times, December 29, 2016, accessed May 18, 2018, http://www.latimes.com/entertainment/arts/la-ca-cm-lovingphotos-20170101-htmlstory.html.
} 


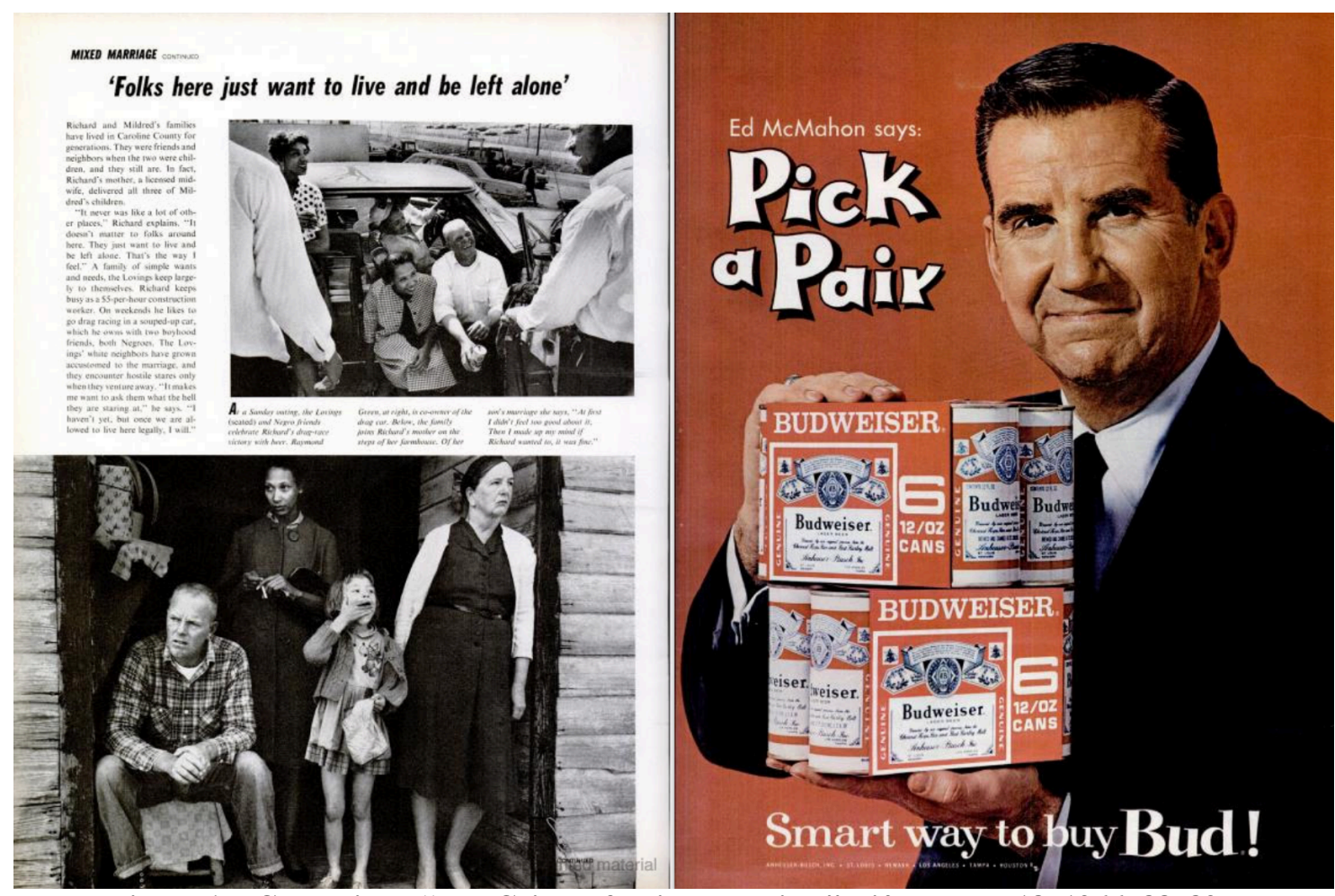

Figure 17: Grey Villet, “The Crime of Being Married,” Life, March 18, 1966, 88-89.

The second of Leen's photographs to reach iconic status is also a group portrait.

This image depicts 'The Irascibles', a group of abstract impressionist artists who famously penned a group letter in protest of the Metropolitan Museum of Art's 1950 exhibit "American Painting Today" (Figure 18). Shot in 1950 and published in Life on January 15,1951 , “The Irascibles" went on to become "practically a best seller for Time Inc. ${ }^{85}$ Leen shot only ten photographs of the group, and described the uncomplicated spirit of the shoot to Vogue arts editor David Bourdon in 1985: "I put out the chairs and I left the positions up to them ... I just made sure all their faces could be seen." ${ }^{86}$ The ten negatives from this assignment reveal Leen's attempt to photograph the group in two different spaces, offering editors a choice and ensuring she achieved at least a single serviceable photograph-one that would present the essence of The Irascibles to Life's

\footnotetext{
${ }^{85}$ David Bourdon, “Sitting Pretty," Vogue, November 1985, 116.

${ }^{86} \mathrm{Ibid}$.
} 
readers. Neither enormous effort nor a deep sense of artistic intention or vision went into the creation of this photograph, which is a departure from Leen's highly posed images depicting fashion and lifestyle trends. Accordingly, Leen's two venerated images are posed in accordance with her typical working method, yet neither constitutes an accurate reflection of her oeuvre.

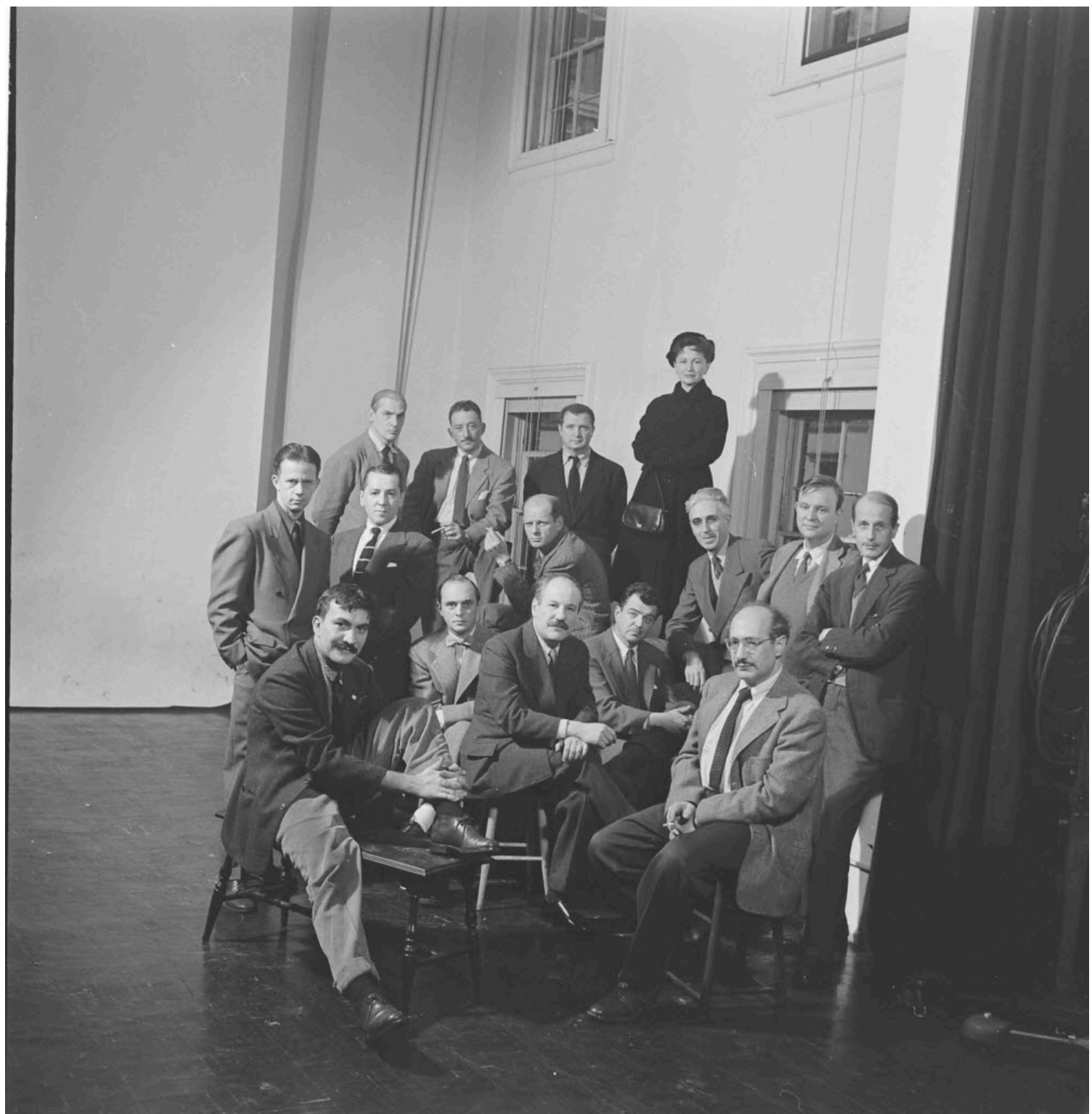

Figure 18: Nina Leen, “The Irascibles," digital reproduction from black and white negative, 1950. Life Photo Collection, Google Arts and Culture. 
Between 1940 and 1970, Life printed an average of 111 pages per week.$^{87}$ In 1955 , the average page count was 126 , with approximately seventeen pages of every issue dedicated to photographic essays ${ }^{88}$ twenty-one comprising news content, and fifty-two featuring full-page advertisements. ${ }^{89}$ This left an average of thirty-six pages allotted to content other than news, photographic essays, or advertisements, constituting twenty-nine percent of the magazine's total contents that year.

Though this quantitatively substantial group pages is seemingly superfluous in content, it is where eighty percent of Leen's work can be found. Leen's contributions to these disregarded pages of the magazine allowed her to establish specific areas of expertise that distinguished her from other contemporaneous photojournalists. Although Leen's photography appeared in nearly half of the magazine's sections during her thirtytwo years at Life, a considerable proportion of her work is distributed between two departments: 'Fashion' and 'Modern Living'. Her most iconic photographs, "Four Generations of an Ozark Farming Family" and "The Irascibles," are not representative exemplars of the content she produced for Life as a result of the dissimilar values held by arbiters of high culture - historians, curators, and critics - and the priorities of the creators of middlebrow mass media.

Leen used a medium format Rolleiflex rather than a $35 \mathrm{~mm}$ camera for her 'Fashion' and 'Modern Living' projects, as speed was not essential when shooting photographs for these two departments. Evidence of Leen's use of 35mm cameras only

\footnotetext{
${ }^{87}$ This average was calculated by using the page counts from the first issue of every month from 1940, 1945, 1950, 1955, 1960, 1965, and 1970. Thierry Gervais indicates that photographic essays comprised approximately ten percent of each issue's content: Thierry Gervais (in collaboration with Gaëlle Morel), The Making of Visual News (London: Bloomsbury, 2017), 112.

${ }^{88}$ The first issue from every month of the year 1955 was examined in order to calculate this number; issues with unusual formatting and pages solely dedicated to advertisements were excluded.

${ }^{89}$ The third issue from every month of the year 1955 was surveyed in order to calculate this number; issues with unusual formatting and pages solely dedicated to advertisements were excluded.
} 
appears much later, in the specific context of animal stories that required faster technology. ${ }^{90}$ The larger negatives produced with Leen's Rolleiflex would also produce sharper images with more detail - qualities more imperative for fashion photography than news. She set up shots carefully and posed her subjects, telling Loengard that "with printing, you can do marvelous things . . . I can make so many changes in printing, which I consider already when I take the picture."91 Unlike photographers racing to capture snapshots while events unfold in front of their lenses, the nature of Leen's assignments and her own approach provided her with a greater degree of mastery over her images. She created photographs rather than catching them, by assembling and posing her subjects, altering her own vantage point, and paying attention to formal elements.
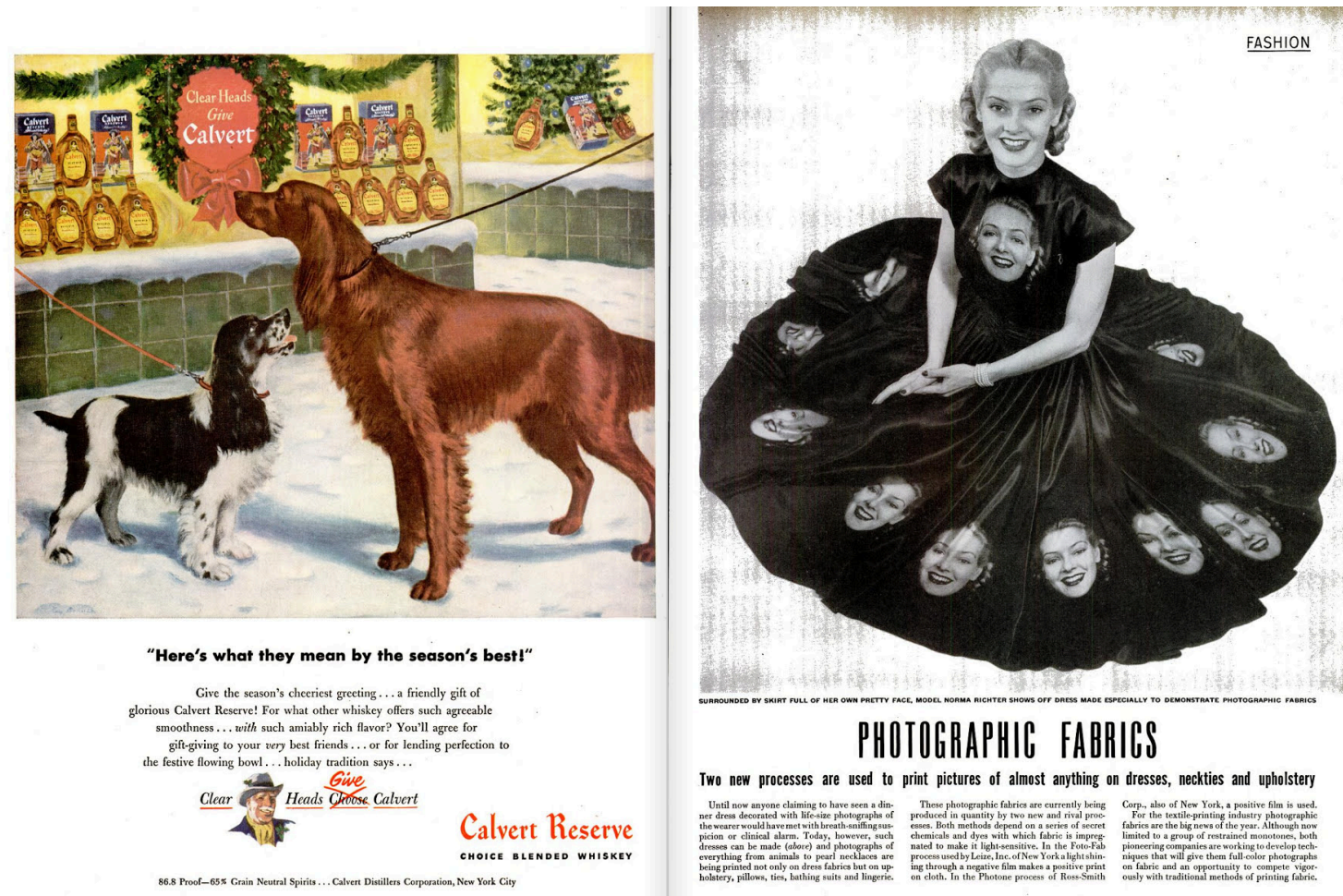

Figure 19: Nina Leen, "Photographic Fabrics,” Life, December 8, 1947, 106-107.

\footnotetext{
90 “Nina Leen,” FYI, New-York Historical Society, The Time Inc. Archives, 1969.
} 
"Photographic Fabrics" was published on December 8, 1947 in the 'Fashion' section of the magazine. The story introduces Life's readers to two novel processes that allowed rival makers to create fabrics printed with photographs. The first spread features a single image of a woman wearing a dress with her own face printed numerous times directly on the fabric, which takes up the majority of the right page; the left holds a fullpage advertisement for Calvert Reserve Choice Blended Whiskey (Figure 19). Leen's photograph was shot in a studio, with the model posed against a white backdrop. The woman is sitting on the floor, with the skirt of her dress spread in a circle around her to show the repetition of the patterned fabric.

The left-hand page of the second spread features five photographs, each with two lines of text below. Two larger images depict the process of creating photographic fabrics in a factory: the first shows rayon embellished with roses being stretched on a long frame, while the second depicts a factory worker moving a bolt of rayon printed with Frank Sinatra's image. The three smaller images show models wearing or interacting with objects made of photographic fabrics (Figure 20). To the right is another full-page advertisement, this time promoting Hinds Honey and Almond Fragrance Cream, a scented lotion. The spread is chaotic, especially with the life-sized hand in the centre of the advertisement competing for the eye's attention.

The third and final spread of "Photographic Fashions" is similarly arranged, with Leen's photographs on the left-hand page and a full-page advertisement for Norge appliances on the right (Figure 21). This advertisement is in colour, once again distracting readers from the story itself. On the left, the upper photograph depicts a cat on a chair upholstered with photographic fabric; below is another showing a woman 
inspecting a fabric wall hanging of a lineman at work. Unlike the photographs taken in the factory, the images showcasing the products are uncomplicated, only showing a model interacting with or wearing an item made from a photographic fabric.
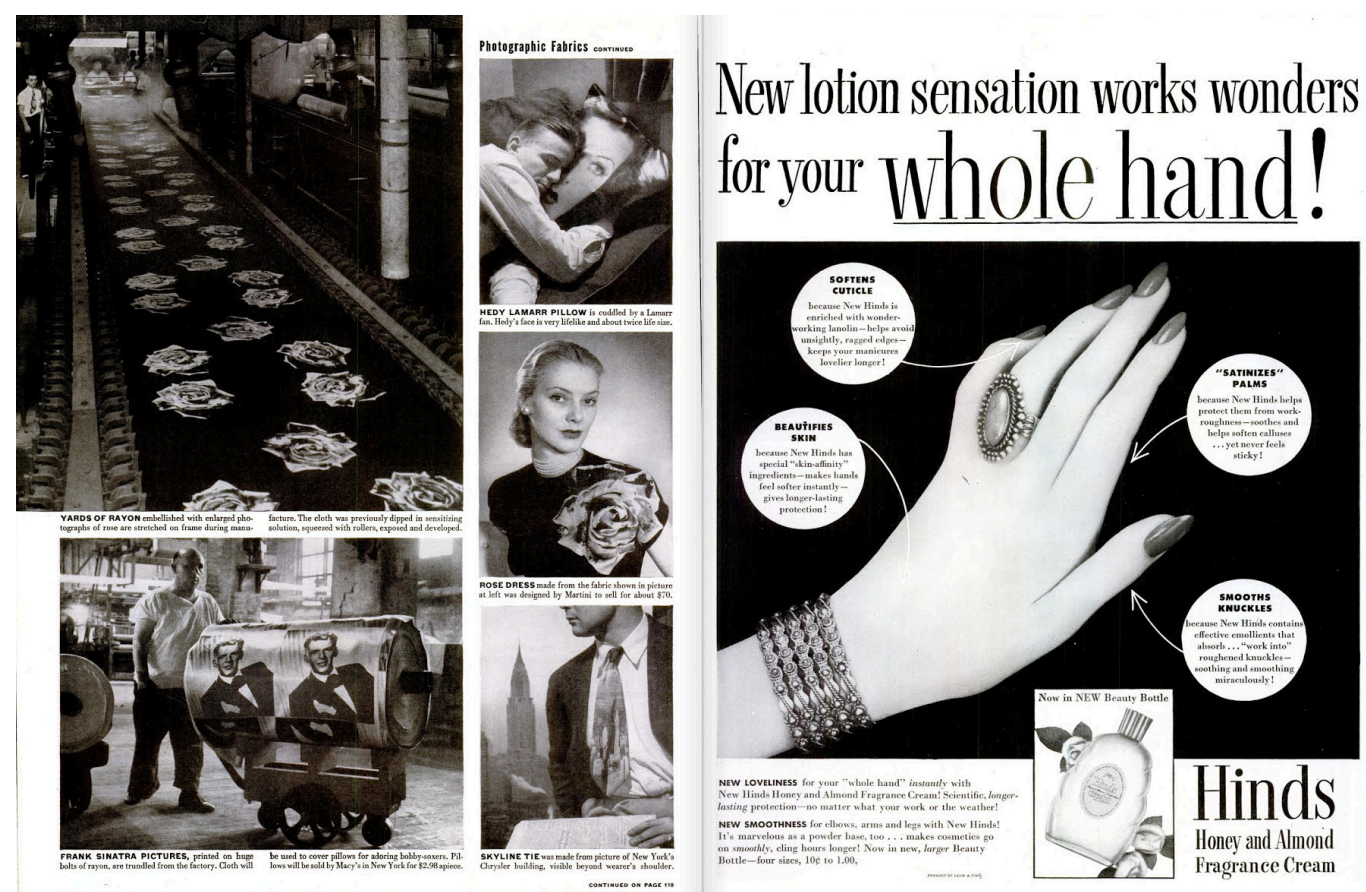

Figure 20: Nina Leen, "Photographic Fabrics," Life, December 8, 1947, 108-109.
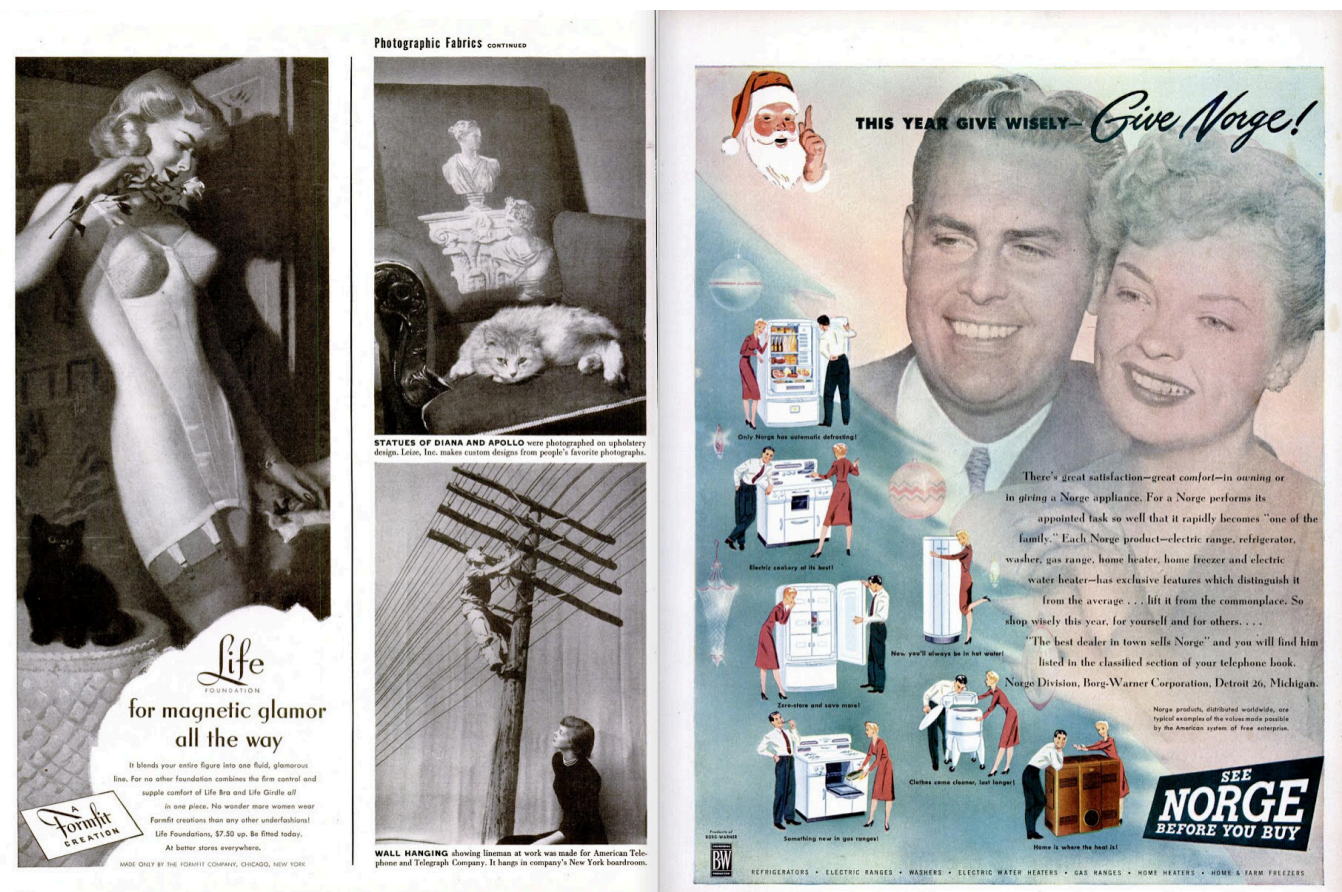

Figure 21: Nina Leen, "Photographic Fabrics," Life, December 8, 1947, 110-111. 
A comparison of the eight photographs published in "Photographic Fashions" with the 278 negatives created for the story offers insight into Leen's intentions and methods. One unpublished image, for example, shows a man wearing goggles and preparing the negatives that were used to create the rose-printed fabric from the second spread (Figure 22). The negatives are wrapped around a tubular light source, likely used to expose the sensitized fabric. Leen was interested in photographic technology, and found this step in the production of photographic fabrics noteworthy enough to shoot. The resulting image is mystifying and engaging. Life's editors, however, were aware that not all readers were familiar with photographic processing, and instead opted for a more straightforward image of the end product.
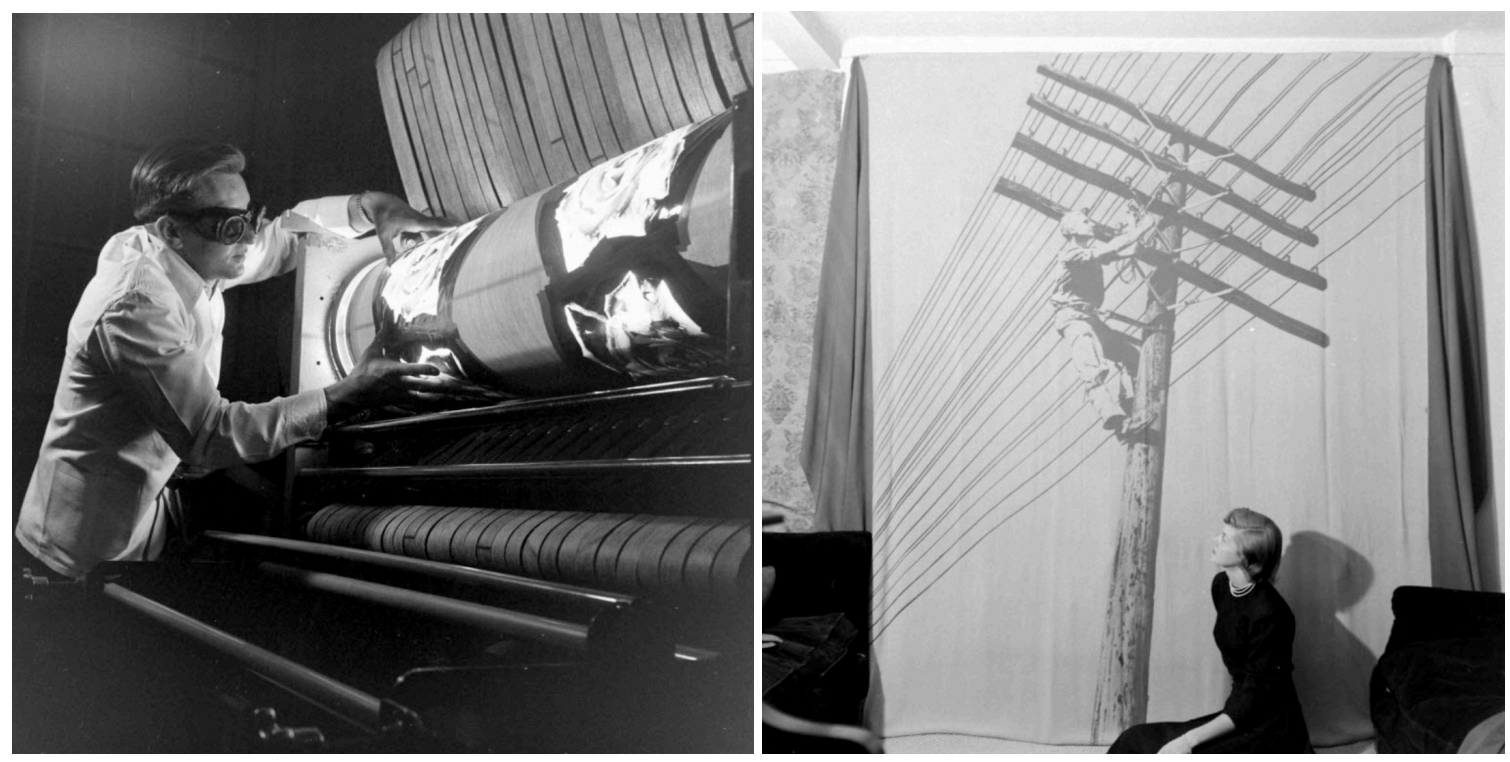

Figures 22-23: "Photographic Fashions," digital reproductions from black and white negatives, December 1, 1947. Life Photo Collection.

The negative used for the final image of the story noted above, showing a woman sitting in front of a photographic tapestry of a workman fixing telephone wires, is also 
unusual (Figure 23). What stands out about this negative is the clutter in the foreground: dark objects in the bottom two corners of the frame clutter the image and confuse the eye, and loose fabric on either end of the wall hanging make the scene appear untidy. Rather than haphazardly forgetting to remove extraneous objects from her composition, the decision to leave objects in the foreground of the photograph might indicate that Leen anticipated post-production. She expected the editors to crop the image, which they did in order to focus readers' attention on the model and her photographic fabric.

Leen assumed a dual role in the process of photographing this single story. As an investigative photojournalist, she explored the fabric factory and made decisions about which parts of the manufacturing process she wanted to photograph; as a commercial photographer she photographed models wearing or interacting with consumer goods fashioned from photographic fabrics. Life's editors then employed Leen's images as advertisements for the invention she was assigned to photograph: the accompanying text informed readers that pillows made from photographic fashions would be "sold by Macy’s in New York for $\$ 2.98$ a piece," while rose dresses were "designed by Martini to sell for about $\$ 70 .{ }^{, 92}$ By coupling engaging images with prices and explanations about where they can make their purchases, the photographs explicitly promoted products and their makers.

The lead image of a four-page story, "Spring Fashions," received subtle edits before being published in the 'Fashion' section on April 12, 1948 (Figure 25). The story covers four consecutive pages, the first featuring a large black and white photograph by Leen, while the following three are filled with colour images of models in front of black

\footnotetext{
92 “Photographic Fashions," Life, December 8, 1947, 108.
} 
and white photographic backdrops by Philippe Halsman. Leen's photograph depicts a model wearing a French hat from Bergdorf Goodman, the chinstrap of which is adorned with a rose. In the negative (Figure 24), blossoms on tree branches behind the subject echo the flower resting at the front of her neck, but background details were lightened and largely cropped out of the frame while preparing the image for printing in the magazine. While the clothing in the colour photographs stood out against the busy backdrops in Halsman's images, Leen's image required more simplicity in order to highlight the hat - the de facto subject of the story. Although no evidence suggests that Leen was involved in the post-production of her own photographs before they went to print in Life, her understanding and acceptance of the editing process accorded with the magazine editors' vision.

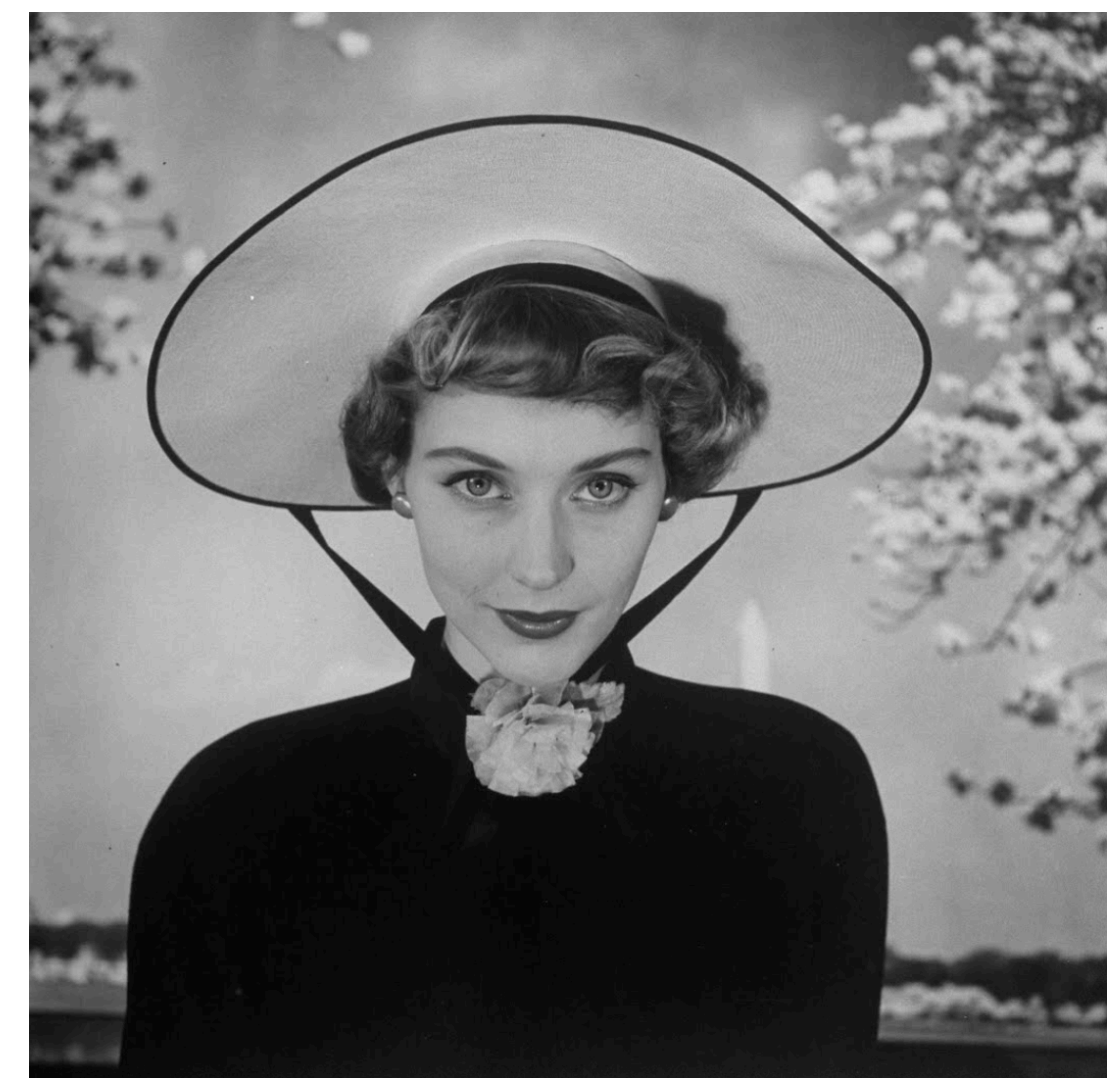

Figure 24: Nina Leen, “New French Hat for Spring,” digital reproduction from black and white negative, April 1948. Life Photo Collection, Google Arts and Culture. 


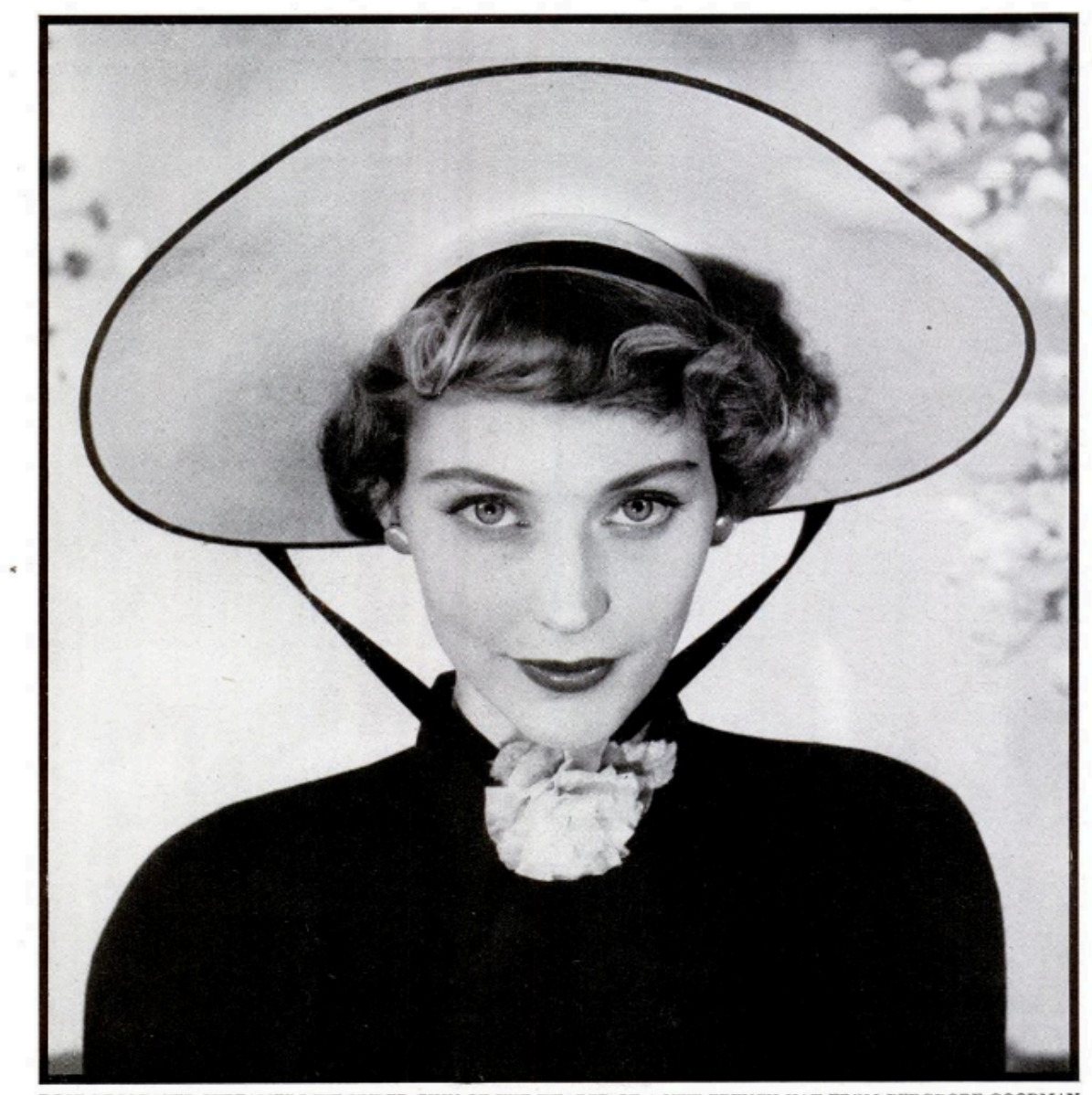

ROSE-DECORATED STREAMERS TIE UNDER CHIN OF THE WEARER OF A NEW FRENCH HAT FROM BERGDORF GOODMAN

\section{Spring Fashions}

New hats, frilly and frothy as ever, are now matched by frilly costumes

After a full year of tumultuous fashion change, flowered hats, as sweet, feminine and gay as they ever have been, were a refreshing constant as the 1948 spring styles made their appearance. But this year, for the first time since the days of Edward VII, the femininity of headgear was matched by the rest of the wearer's costume. U.S. Easter parades saw not on.y ultrasop'isticates wearing girlish, tied-under-the-chin hats (above). They also saw multiple petticoats, big skirts
12 inches from the ground, slender shoes and tight-waisted jackets in numbers that confirmed American acceptance of the past year's disputed trends. One especially new item they also saw: the short, very full jacket ( $p .92)$ which, when combined with the full skirt, gives the wearer a typically Victorian silhouette. On the following pages Photographer Philippe Halsman has posed some of these frilly new spring clothes and hats against photomurals of traditional spring scenes.

Figure 25: Nina Leen, “Spring Fashions,” Life, April 12, 1948, 90. 
The soft stories that comprise the majority of Leen's output do not typify conventional photojournalism - they are not shocking, emotional, or urgent. They do, however, characterize the broad notion of photojournalism that Luce developed and presented to Americans through Life.$^{93}$ If Life's photojournalists were to deliver "a compelling summary of the week, ${ }^{, 94}$ they could certainly accomplish this aim through photographic essays and news photographs, but they would also do so through the creation of soft news photographs that comprised the vast majority of Leen's work, and a substantial quantity of Life's images.

While thought-provoking, poignant, or newsworthy photographic essays have been discussed, venerated, and canonized, a 1967 essay written by John Szarkowski and published in Aperture challenged this notion by reminding readers of the illustrated magazine's classification as a mass medium. "Popular magazines, newspapers, outdoor advertising and television programmes" Szarkowski wrote, "are conceived as experiences to be flipped through, driven past or glanced at, and it would be irrational and smallminded to belabour them for succeeding at their appointed task." ${ }^{95}$ James L. Baughman offered support for this notion in his discussion of Life's readership, which was likely made up of a smaller number of readers than 'thumbers': ${ }^{96}$ individuals unthinkingly leafing through pages at the doctor's office or beauty salon.

Indeed, with an average of one hundred pages printed each week, and thirty-six years of weekly publication, Life required enough photographs to fill well over one

\footnotetext{
${ }^{93}$ The origin of the term 'photojournalism' is contested. For Luce's contribution, see Baughman, Henry R. Luce and the Rise of the American News Media, 2. Alfred Eisenstaedt was the first to publish the word in a 1938 article: Wilson, "The Corporate Creation of the Photojournalist," 134.

${ }^{94}$ Ibid.

${ }^{95}$ John Szarkowski, "Photography and the Mass Media," Aperture 13, no. 3 (1967): 53.

${ }^{96}$ Baughman, "Who Read Life?," 43.
} 
hundred thousand pages. Considering that multiple photographs were arranged on each of its pages, the total number of photographs printed in the magazine is probably immeasurable. Thirty-two years spent working for Life taught Leen to recognize that many of her photographs were not as special as "Four Generations of an Ozark Farming Family" or "The Irascibles:" "Some are special. Some are not special. Some stories are important or-or talked about. Some stories just - just little stories, which every magazine needs to fill up. You know? Then, not every, not all the stories are unique or anything like that." ${ }^{.97}$

97 "Unchecked and Uncorrected Transcript of Interview with Nina Leen" by John Loengard, interview, New-York Historical Society, The Time Inc. Archives, January 14, 1992, 35. 


\section{Marketing Leen}

The clichéd debate as to whether gender inherently affects the work of a photographer has outlived Nina Leen. While outlining this matter in a 1998 American Journalism Review article entitled "Getting the Picture," Sherry Riccihardi cited various scientific studies that attest to an innate distinction between men and women, which ultimately impacts the photographs created by either gender. Differences in the ways that male and female brains are hardwired were used to justify why "men hunt for the point; women gather the detail," or, put more broadly, how "women perceive and construe social reality differently from men." ${ }^{.98}$ When asked by John Loengard if her gender allowed her to take photographs that men could not, Leen responded by referencing her 1944 photographic essay “Teen-Age Girls.” Leen began by citing her ability to befriend her subjects as a strength, before adding, "if a man had been there in my place with the same approach, they might have been just as happy. ${ }^{, 99}$ Leen did not subscribe to this essentialist theory of gender-she acknowledged women and men were treated differently, but denied that her images were inherently affected by her gender.

Laura Wexler prefaced her study of the first American women photojournalists by reminding readers that "it would be a mistake to imagine white women's 'ways of seeing' as all the same." ${ }^{100}$ In her introduction to Tender Violence: Domestic Visions in an Age of U.S. Imperialism, Wexler defended her decision to continuously draw upon the strengths and limitations of gender by simultaneously evoking "the need for a nonessentialist

\footnotetext{
${ }^{98}$ Sherry Riccihardi, “Getting the Picture," American Journalism Review 20, no. 1 (January/February 1998): 30.

${ }^{99}$ The editors of Life, "Nina Leen," 241.

${ }^{100}$ Laura Wexler, "Introduction," Tender Violence: Domestic Visions in an Age of U.S. Imperialism (Chapel Hill: The University of North Carolina Press, 2000), 11.
} 
theory of gender that integrates race and class with the history of photojournalism.",101 Following Wexler's counsel, this discussion seeks to avoid assumptions that directly connect Leen's gender to the content of her photographs. Rather, one cause for Leen's waning reputation can be located in the gendered ways in which Life marketed her: Life exercised power in shaping Leen's public persona, specifically through the promotion of her career as an antithesis to the mythologized figure of the heroic, globetrotting photojournalist.

During its thirty-six years of operation as a weekly magazine, Life offered staff (or comparable) contracts to only six women: Leen, Margaret Bourke-White, Marie Hansen, Martha Holmes, Hansel Mieth, and Lisa Larsen. Of these six, Leen was second only to Bourke-White in terms of both years spent working for the magazine and quantity of photographic production. Hansen spent eight years working for the magazine; Holmes worked for Life for twenty-nine years; Mieth only lasted eight years; and Larsen held her post for fifteen years.

Life's decision to provide Leen with any exposure at all substantiates her place in the pecking order. According to Beth E. Wilson's observations regarding Life's public treatment of its staff photographers, Leen's circumstances were anything but ordinary:

Other photographers had to be satisfied with receiving their credit in a difficult-toread block of type hidden near the bottom of the masthead/front matter, set in miniscule type. Only a handful of photographers, including Bourke-White, Robert Capa, W. Eugene Smith, and a few others received this sort of prominent play, typically when the photographer him- or herself had become part of the story in some noteworthy way. ${ }^{102}$

\footnotetext{
${ }^{101}$ Wexler, "Introduction," Tender Violence, 11.

${ }^{102}$ Beth E. Wilson, "The Corporate Creation of the Photojournalist: LIFE Magazine and Margaret BourkeWhite in World War II," Journal of War \& Culture Studies 9, no. 2 (May 2016): 144-145.
} 


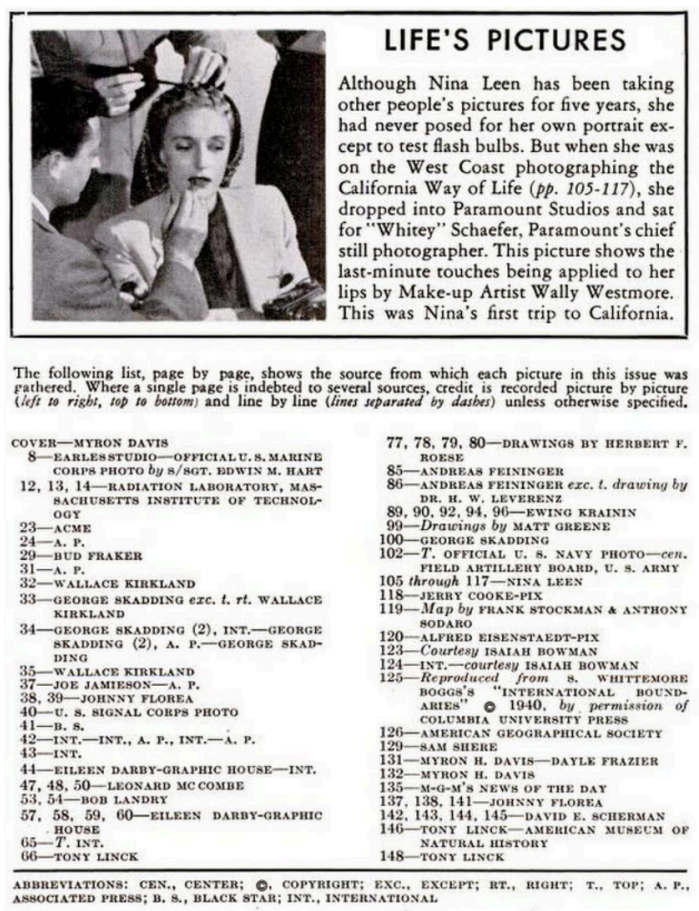

Figure 26: "Life's Pictures," Life, October 22, 1945, 29.

Wilson illustrated this point with a standard 'Contents' page from Life. She distinguished between the small box containing "miniscule" type where photographers are credited for their images, page by page, and the 'Life's Pictures' feature situated directly above it. The latter highlights a single photographer and their adventures in picture-taking by way of a paragraph of text accompanied by a portrait (Figure 26) ${ }^{103}$ Leen, along with a handful of other photographers, was featured twice in this segment of the magazine in 1945 - her first year working on contract for the magazine - as were Dmitri Kessel, Robert Capa, Ralph Crane, Eliot Elisofon, David Scherman, J. R. Eyerman, Ralph Morse, and Kosti Ruohomaa. Of these eight other photographers, only Scherman and Ruohomaa were not part of Life's staff. Leen and Bourke-White were the only women staff photographers featured in 1945, while Leen, Bourke-White, and Larsen each received mentions in 'Life's Pictures' in 1946. 'Life's Pictures' appeared in every issue of 1945

${ }^{103}$ Ibid., 144-146. 
and 1946, yet Werner Wolff was never promoted through this avenue. ${ }^{104}$ 'Life's Pictures' was one venue by which Life could showcase its exceptional staff photographers to its readers, and Leen's repeated appearances in this feature demonstrate her elevated status at the magazine.

Leen was highlighted in 'Life's Pictures' on August 20, 1945, three months after being offered a contract with Life magazine. She had published a story in the issue entitled "Life Goes House-Fixing," following four women traveling from New York City to the Catskill Mountains in order to help a new homeowner repair his property, because manpower was scarce during World War II. The story included two spreads, the first featuring seven black and white photographs of the women doing various tasks, such as painting or trimming trees (Figure 27). The second spread contained three photographs positioned centrally, with the outer halves of both pages dedicated to advertisements. The entire story was accompanied by only two paragraphs of text on the first page, along with one- or two-line captions under each image.

\footnotetext{
${ }^{104}$ Grey Villet could not have been featured in 'Life's Pictures' during these two years because he only began working for Life in 1954.
} 

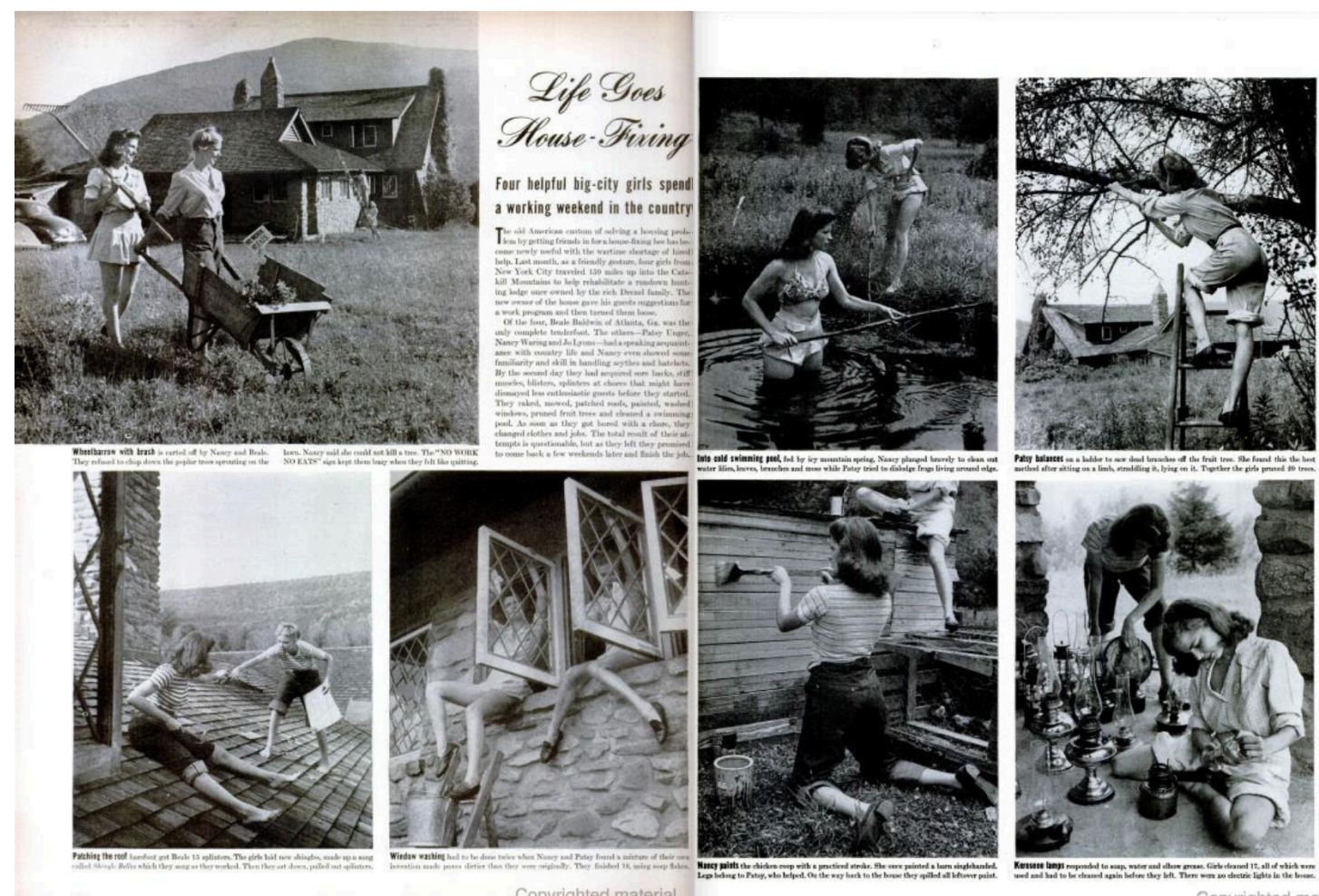

Figure 27: Nina Leen, “Life Goes House Fixing,” Life, August 20, 1945, 118-119.

While the story attempts to show the women acting naturally, Leen's compositions appear decidedly constructed. The image in the top left corner, for example, shows two women cheerily carrying tools into a field in the foreground, while two others are seen in the distance, one climbing a ladder while the other supports her (Figure 27). A photograph on the second spread depicts a woman placing her hair in curlers; according to the text she was a model for Jay Thorpe in New York. Instead of facing the model, Leen chose to stand behind her and photograph her reflection in a circular mirror. The resulting image is intimate, with the viewer invited to see the subject as she sees herself (Figure 28). The editors exaggerated this sense of familiarity by darkening the image, and by cropping it to show only the young woman's reflection, eliminating any trace of another woman standing beside her, holding a lamp (Figure 29). 


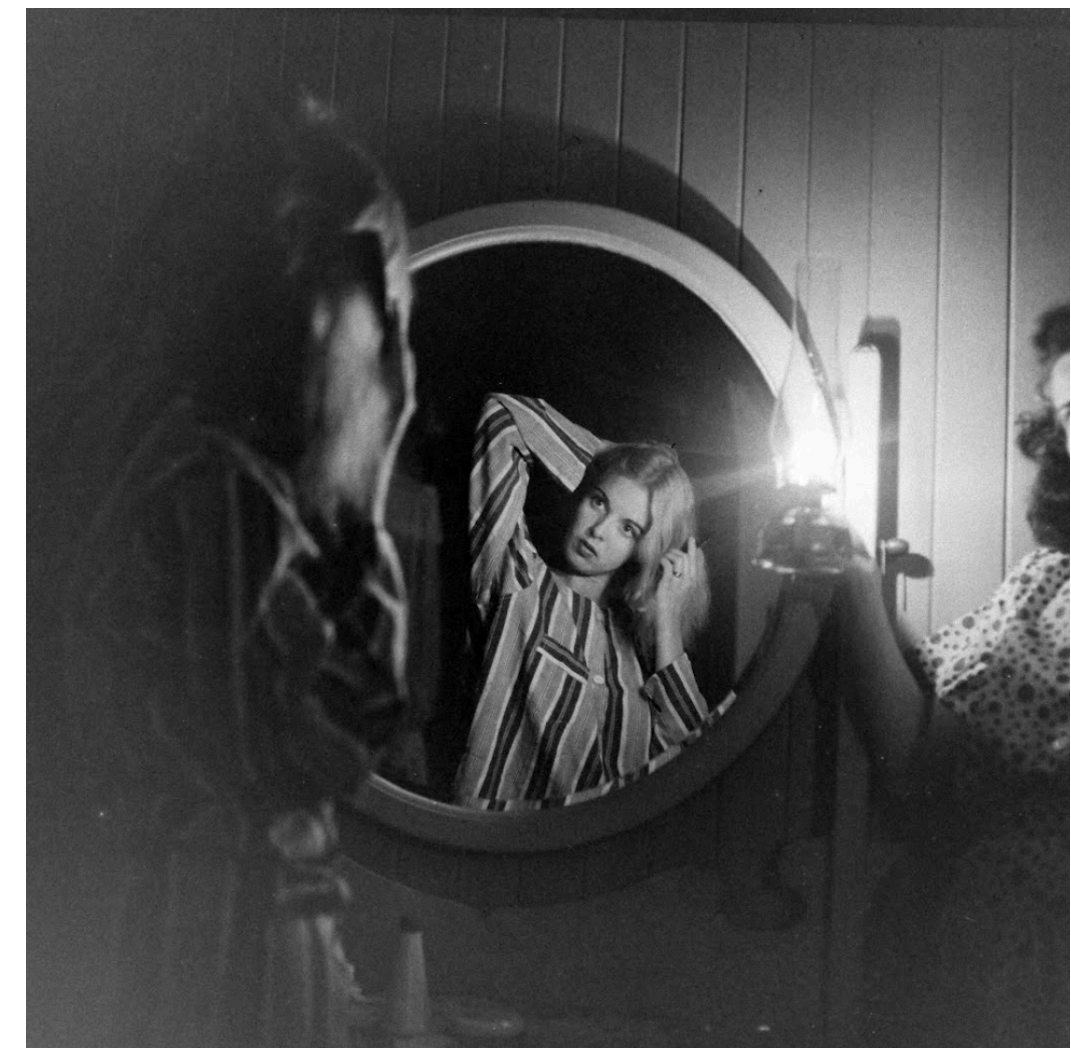

Figure 28 (left): Nina Leen, “Life Goes House Fixing," digital reproduction from black and white negative, July 1945. Life Photo Collection, Google Arts and Culture.

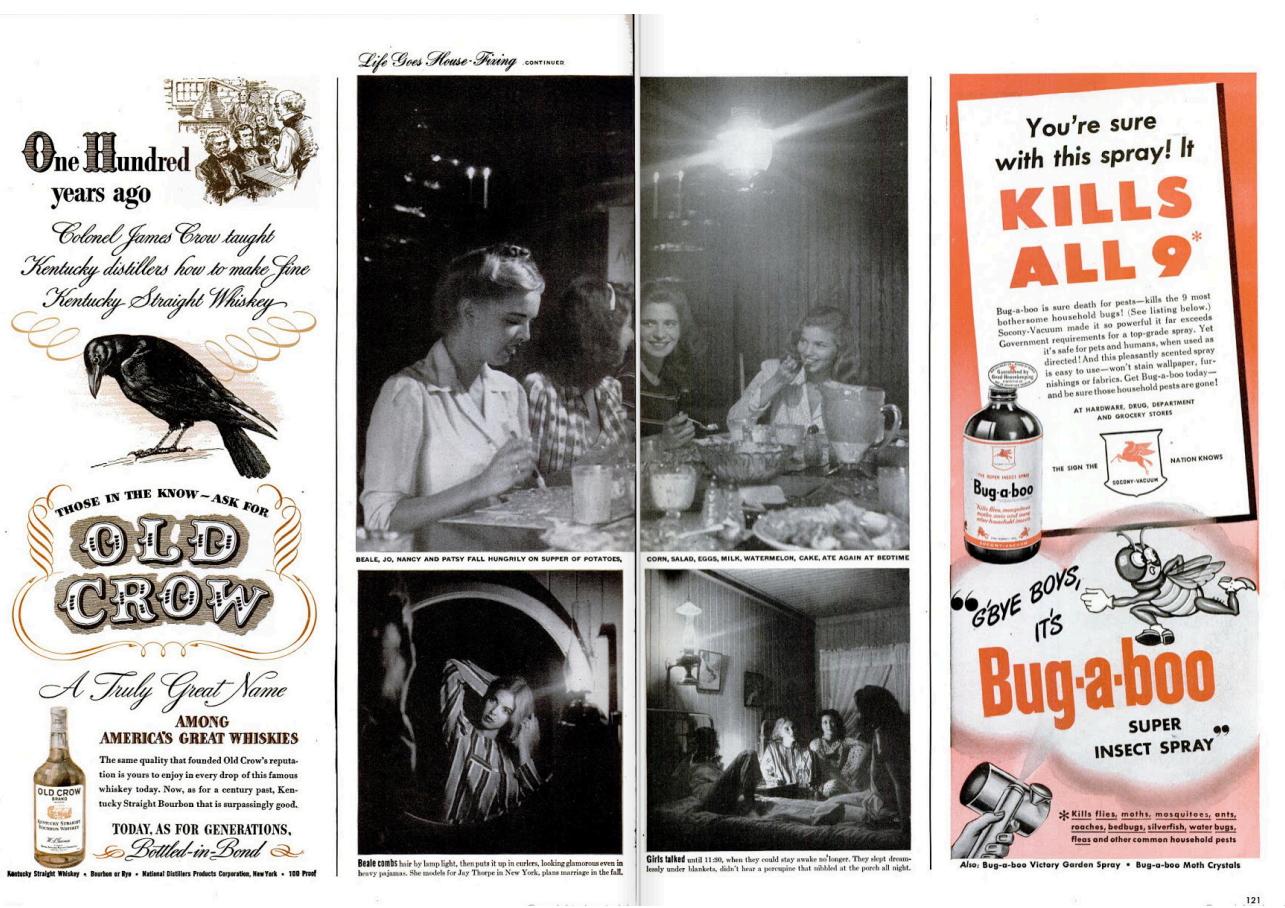

Figure 29: Nina Leen, “Life Goes House Fixing,” Life, August 20, 1945, 120-121. 
Leen's 'Life's Pictures' feature accompanying this story begins “Nina Leen, who photographed the house-fixing party (pp. 118-121), has two deep and lasting interests: photography and getting sun-tanned."105 Rather than discuss her thoughts on women replacing male workers during the war, Life's editors opted to use these twelve lines of text to foreground Leen's femininity and a stereotypically female interest of hers.

Leen was again spotlighted in 'Life's Pictures' in the following year, on July 22, 1946, in the same issue as her eleven-page photographic essay "The North Shore, Long Island." Once more Life's editors mentioned her propensity for "sunworshipping," this time writing, "Although she lost part of a beautiful suntan during this assignment, Miss Leen enjoyed Long Island." 106 In the August 11, 1941 'Life's Pictures' feature, reproduced by Wilson in “The Corporate Creation of the Photojournalist," Life's editors referred to Bourke-White as a "Photomaster" who triumphantly "had access to Russian circles which few foreigners ever attain," which helped her to create the "revealing pictures of Moscow on the eve of the German invasion" published on subsequent pages of that very issue. ${ }^{107}$ Compared to Bourke-White, who was presented as gallant and globetrotting, ${ }^{108}$ the particular rhetoric used to market Leen was often less complimentary, with the magazine emphasizing Leen's gender in a blithe and 'humorous' manner.

Leen was also quickly typecast as Life's resident 'animal photographer', although the magazine never defined this term outright. Aside from her first-ever Life story, Leen's animal-related assignments were largely amusing and entertaining stories during the first

\footnotetext{
${ }^{105}$ Life, "Life's Pictures," August 20, 1945, 23.

${ }^{106}$ Life, "Life's Pictures," July 22, 1946, 17.

${ }^{107}$ Life, "Life's Pictures," August 11, 1941, 15.

${ }^{108}$ Wilson, "The Corporate Creation of the Photojournalist," 149.
} 
half of her career at the magazine, rather than the serious studies of wild species she wished to pursue. ${ }^{109}$ Leen told Loengard she thought "This is heaven, to be a zoo photographer" when using her first camera at the Bronx Zoo in 1939. ${ }^{110}$ While Leen would have been overjoyed to have spent her life photographing zoo animals, the frequency of Leen's trips to the zoo slowed as her career progressed. Animal stories comprised nine percent of Leen's total Life assignments, and between 1940 and 1955 fifteen of her seventeen animal assignments depicted pets or domesticated animals, including a 1944 story about Tommy Tucker the celebrity squirrel (Figure 30) and an ongoing feature about her own dog, Lucky.

Leen's romanticized version of what it meant to be an animal photographer could hardly be realized through the stories she was assigned during the first half of her career-serious animal stories would have to wait. She remained patient until editors would allow her to photograph the subjects she found most interesting: "A lot of stories were my own idea, and I was just thankful that after a while . . . they'd okay it." ${ }^{111}$ In 1955, Leen's photographic output for Life decreased in quantity dramatically. Although no indication exists as to whether this was Leen's choice or that of Life's executives, this change in tempo provided the photographer with the time to pursue more involved, research-based animal stories. Leen's first story as a wildlife photographer, “Dazzling Collection of Pheasants from Asia is Assembled in North Carolina," was published in October 15, 1956, for which she also received a byline (Figure 31).

\footnotetext{
109 "Unchecked and Uncorrected Transcript of Interview with Nina Leen” by John Loengard, interview, New-York Historical Society, The Time Inc. Archives, January 14, 1992, 4.

${ }^{110}$ Ibid.

${ }^{111}$ Ibid., 1.
} 

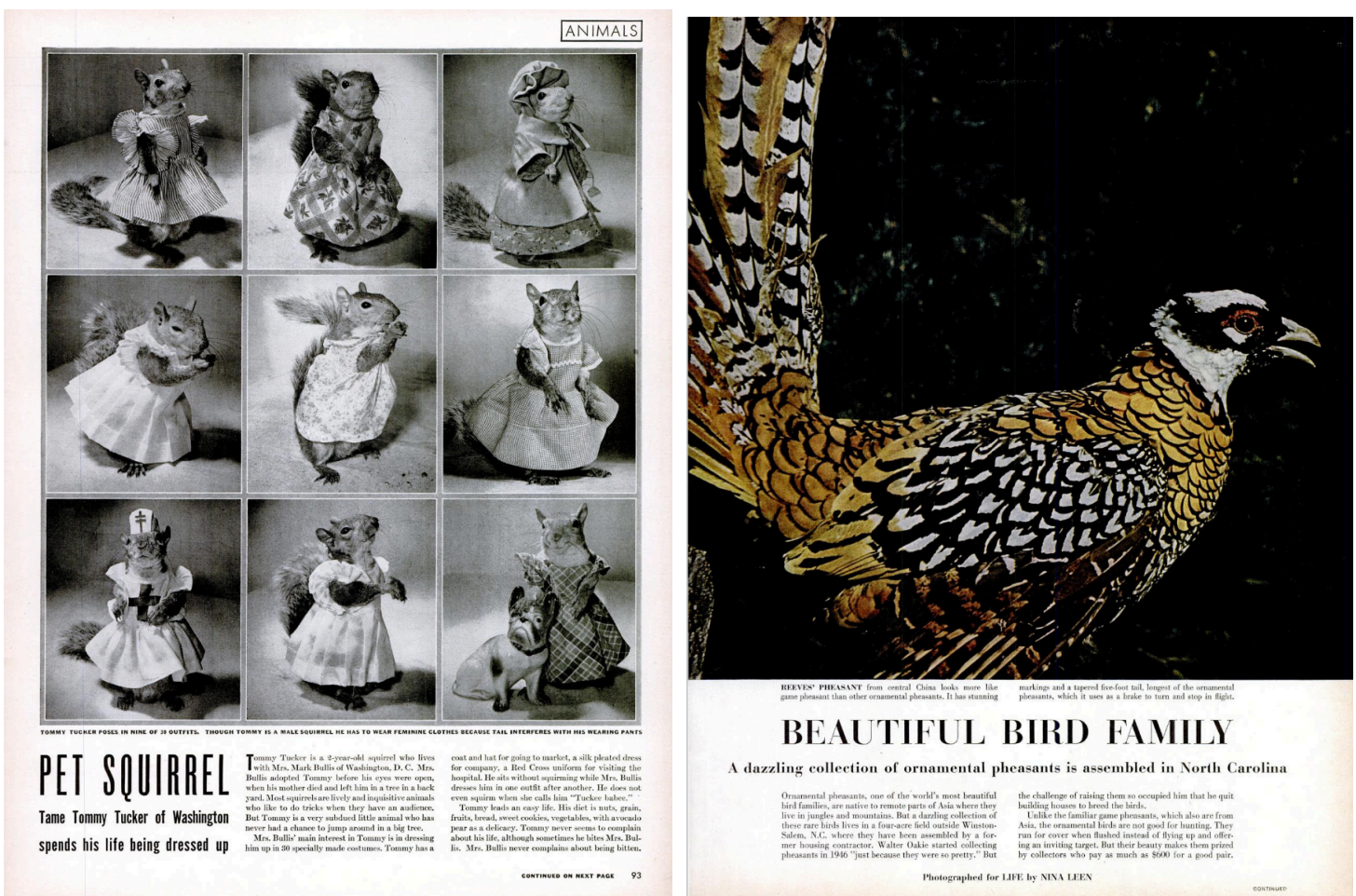

BEAUTIFUL BIRD FAMILY

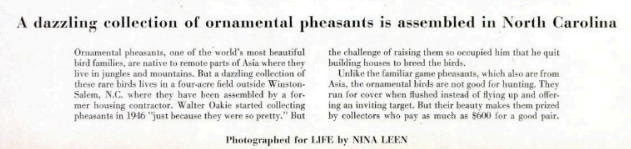

Figure 30 (left): Nina Leen, "Pet Squirrel," January 31, 1944, 93.

Figure 31 (right): Nina Leen, "Dazzling Collection of Pheasants from Asia is Assembled in North Carolina" Life, October 15, 1956, 123.

Ylla (born Camilla Koffler; 1911-1955) was another animal photographer working at the same time as Leen. Life magazine published Ylla's photography on multiple occasions: some stories depicted wild animals while others showcased pets. Ylla's style of photography is comparable to Leen's, as is her biography: Ylla studied sculpture in Paris, while Leen received an education in fine art in a major European metropolis; Ylla spent prolonged periods of time with animals in order to photograph them, as did Leen; both photographers raised uncommon pets, with Ylla owning two bear cubs for a short time and Leen having raised snakes and monkeys as a young girl; both photographers also published numerous books of animal photography. ${ }^{112}$ On April 25, 1955, in an article announcing Ylla's death, Life wrote of her growth from pet portraitist

\footnotetext{
${ }^{112}$ John O'Reilly, “Tragedy in India," Sports Illustrated, April 11, 1955; "Unchecked and Uncorrected Transcript of Interview with Nina Leen" by John Loengard, interview, New-York Historical Society, The Time Inc. Archives, January 14, 1992, 4.
} 
to "the most widely known animal photographer in the world," chronicling her movement from the studio into "wild and primitive settings" as her career progressed. While wildlife photography is not inherently more respectable than portraits of pets, Life's treatment of Ylla's career demonstrates how the former has long been associated with noble qualities such as bravery and speed, while the latter has amateurish connotations. Ylla undoubtedly ventured into the wild, ultimately dying after being thrown from a Jeep while photographing ox-cart racing in India, ${ }^{113}$ but even the wildest of Leen's animal photography was created under controlled conditions, for example using "special photographic cages and the cooperation of zoos and leading naturalists."114

The caption accompanying the final photograph of Leen's first-ever Life publication, “250-Year-Old Turtles at Bronx Zoo Fight for 200-Year-Old Female,” reads “These pictures were taken by Nina Leen, famed in Europe for her picture studies of animals in zoos." ${ }^{115}$ This contradicts Leen's own testimony, in which she revealed that “soon after I arrived in America from Europe in 1939, I began walking around the zoo with a Rolleiflex. I didn't know anything about taking pictures, so I just followed the instructions on the back of the camera." 116 The background Life concocted for its recent photographic hire served to justify the inclusion of her images in the magazine. By articulating her know-how - factual or not - a level of trustworthiness was affixed to her images, and therefore to Life itself.

Life benefited from pigeonholing Leen as an animal photographer by showcasing the magazine's diversity and appealing to a niche audience, while simultaneously

\footnotetext{
${ }^{113}$ John O’Reilly, “Tragedy in India,” Sports Illustrated, April 11, 1955, 60.

${ }^{114}$ George P. Hunt, "Discovering the Beauty of Bats," Life, March 29, 1968, 3.

115 “250-Year-Old Turtles at Bronx Zoo Fight for 200-Year-Old Female,” Life, April 1, 1940, 46.

116 "Batwoman," FYI, New-York Historical Society, The Time Inc. Archives, July 11, 1964.
} 
denying her the serious studies she wished to produce. Had she not desired the money, reputation, and opportunity for growth offered by a career at Life, Leen would have been more than content spending her life photographing zoo animals. ${ }^{117}$ Her personal interests were used as a marketing tool during the first part of her career, exaggerating her gender and the playful tone of her animal photography in order to portray Life's cheerful side. Wilson asserts that “Bourke-White's star status shone brighter because of (not despite) her gender," 118 and yet the opposite can be said of Leen, about whom Life painted a feminized, almost farcical, portrait. With so few women staff photographers working for the magazine, and given the small percentage of Life photographers who were presented as voyaging heroines, Life used Leen to present a different - but equally present - face of the magazine.

${ }^{117}$ The editors of Life, "Nina Leen," 235.

${ }^{118}$ Wilson, "The Corporate Creation of the Photojournalist," 142. 


\section{PART II: Achieving Autonomy (1955-1972)}

\section{Experimentation and Expression}

It was only once Leen had established herself as an invaluable asset that she could afford to experiment more freely. Leen took a casual yet assured approach to her experimentation, telling Loengard, "And I could afford to experiment. I did. And sometimes it turned out." ${ }^{\text {"19 }}$ Leen's knowledge of photography had developed exponentially throughout her first fifteen years at the magazine, and the autonomy she achieved in the second half of her career resulted in a number of stories and photographs that were dissimilar from the profusion of fashion and lifestyle images produced up until that point. Leen's output remained varied during this period, including twenty-one fashion stories, four concerning architecture and five on politics, and ten contributions to news stories.

The most significant change can be seen in the photographic essays Leen produced from 1955 onward, with their subject matter requiring different creative and technical skills to photograph. Leen published three photographic essays in the span of a twelve-month period from October 1957 to October 1958, all of which relied more on creativity and expression than they did on indexicality or direct representation. The first was "Ghostly American Legends: The Early Tales Die Hard Even in This Skeptical Age," which ran in the October 28, 1957 issue of Life (Figure 32), followed by "Five Views of a Marriage from Members of the Wedding" published on July 28, 1958, and finally

\footnotetext{
119 "Unchecked and Uncorrected Transcript of Interview with Nina Leen" by John Loengard, interview, New-York Historical Society, The Time Inc. Archives, January 14, 1992, 35.
} 
"Moments of Happiness Portrayed in Pictures: Poetic Interpreter Evokes the Classic Aspects of Joy" on October 27, 1958.

The mid-1950s also signaled a shift in the quantity and character of Leen's photographic output for Life. Whereas her photographs were published in 265 issues of Life between 1940 and 1955, Leen's last sixteen years spent working for the magazine resulted in photographs appearing in only 108 issues. Leen published twenty stories in seventeen different issues of the magazine in 1954, including one photographic essay that was accompanied by a cover image. The following year her work appeared in only ten stories throughout ten issues, and she created no photographic essays and no covers for the magazine. From 1940 to 1954 , Leen produced an average of twenty-three stories per year, a number that dropped to seven per year between 1955 and 1972. Of Leen's fortyeight Life covers, forty-three were published in the first fifteen years of her career at the magazine. By allowing executives to market her personality as they pleased, she implicitly supported the magazine and the eminent photographs she created brought attention to Life: "Four Generations of an Ozark Farming Family" and "The Irascibles" were said to have "exemplified the style of photography that contributed to Life's heralded reputation" in the issue of Life's internal staff newsletter in which the photographer's death was announced. ${ }^{120}$ While Szarkowski noticed in 1967 that "many of today's best photographers are fundamentally bored with the mass media, and do not view it as a creative opportunity," 121 submitting to the wishes of Life's editors for fifteen years had, by the mid-1950s, paid off for Leen. Finally, she was able to utilize Life's

\footnotetext{
${ }^{120}$ FYI, New-York Historical Society, The Time Inc. Archives, 1995.

${ }^{121}$ John Szarkowski, "Photography and the Mass Media," Aperture 13, no. 3 (1967): 53.
} 
support in order to pursue projects that reflected her enduring passion for both art and animals.

A recurring challenge undertaken by Leen in the latter half of her career was to photographically depict the intangible and the ethereal. While the value of a photograph classified as photojournalism typically relies on its veracity, Leen was able to disregard the truth factor in a number of projects. In order to photograph emotion and spirits, she developed a technique that assisted her in the creation of a number of stories for Life in the late 1950s, including "Ghostly American Legends," "Five Views of a Marriage from Members of the Wedding," and "Moments of Happiness Portrayed in Pictures." She fashioned a filter of sorts that would distort her images in order to communicate both eeriness and airiness - depending on the subject. An article explaining this innovation to Life's advertisers explained:

The degree of soft focus and color effects in selected areas of these pictures is carefully controlled by means of pieces of gelatins, plain and colored, which are stuck to areas of the camera lens with scotch tape. This technique evolved from months of patient experimentation and Nina Leen has made it uniquely her own. $^{122}$

122 "A Picture Portrayal of Moments of Happiness," The Story Behind the Stories in Life, Oct 27, 1958, New-York Historical Society, The Time Inc. Archives. 

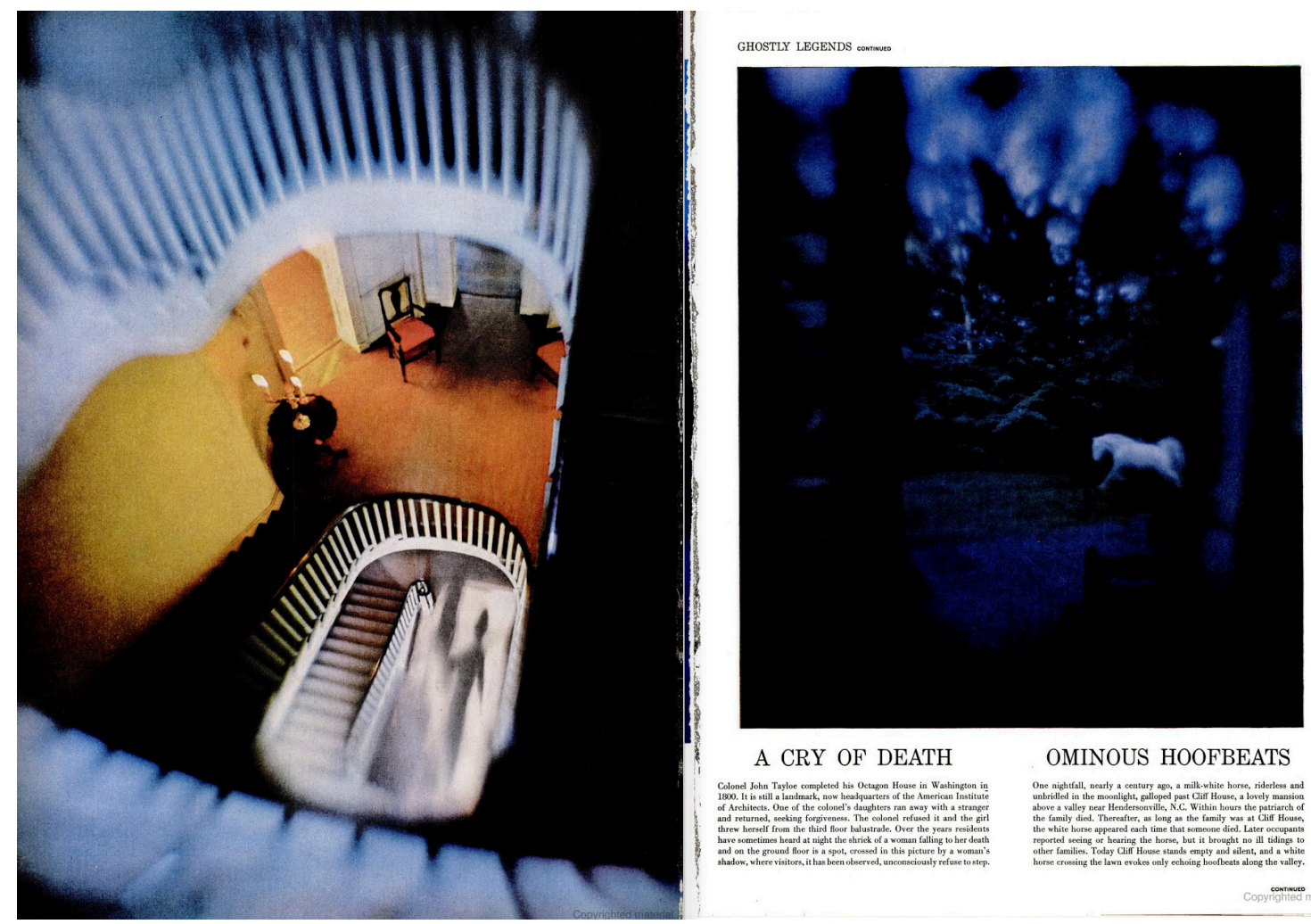

A CRY OF DEATH

OMINOUS HOOFBEATS
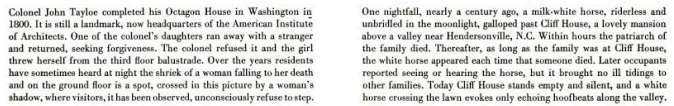

Figure 32: Nina Leen, "Ghostly American Legends: The Early Tales Die Hard Even in This Skeptical Age," Life, October 28, 1957, 90-91.

The first of these stories, "Ghostly American Legends," was well received: it won Leen first place in a magazine colour story competition co-sponsored by Encyclopedia

Britannica, the National Press Photographers Association, and the University of Missouri School of Journalism in $1957 .{ }^{123}$ The colour transparencies produced for this essay attest to Leen's technological propensity as well as her creativity. She experimented with gelatin filters of various colours in order to convey moods and atmospheres (Figures 3335).

123 “Winning Photos and the Makers," Life, May 19, 1958, 14. 

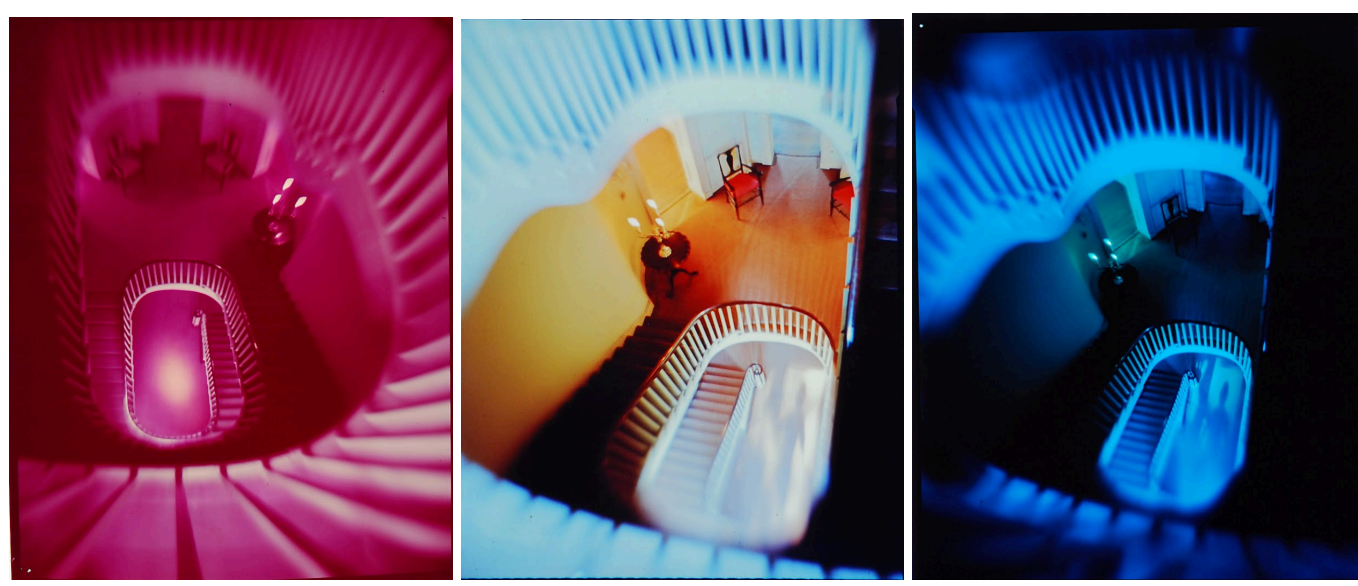

Figures 33-35: Nina Leen, “Ghostly American Legends," 1957, digital reproductions from colour transparencies, 1957. Life Photo Collection, Google Arts and Culture.

Even with the experience of two essays behind her, Leen's gelatin filter technique proved complex and time-consuming. In order to realize the final photograph in her 1958 essay "A Picture Portrayal of Moments of Happiness" (Figure 36), published in the 'Photographic Essay' section of the Magazine, the photographer required ten exposures and half a day of preparation. ${ }^{124}$ The photograph depicts a light blue Volkswagen Beetle driving away from the camera on an empty country road; the ribbons secured to its bumper are the only indication (other than the caption) that the driver and passenger are newlyweds, commencing their new life together. As a result of Leen's gelatin strip technique most of the detail in the image is obscured, aside from the car itself. A single tree, the road in the foreground, and the landscape on either side of the car are softened and blurred; dark, vignette-like shadows frame the bottom of the photograph. The couple seemingly has nowhere to go but forward. 124 “A Picture Portrayal of Moments of Happiness," The Story Behind the Stories in Life, Oct 27, 1958,
New-York Historical Society, The Time Inc. Archives. 


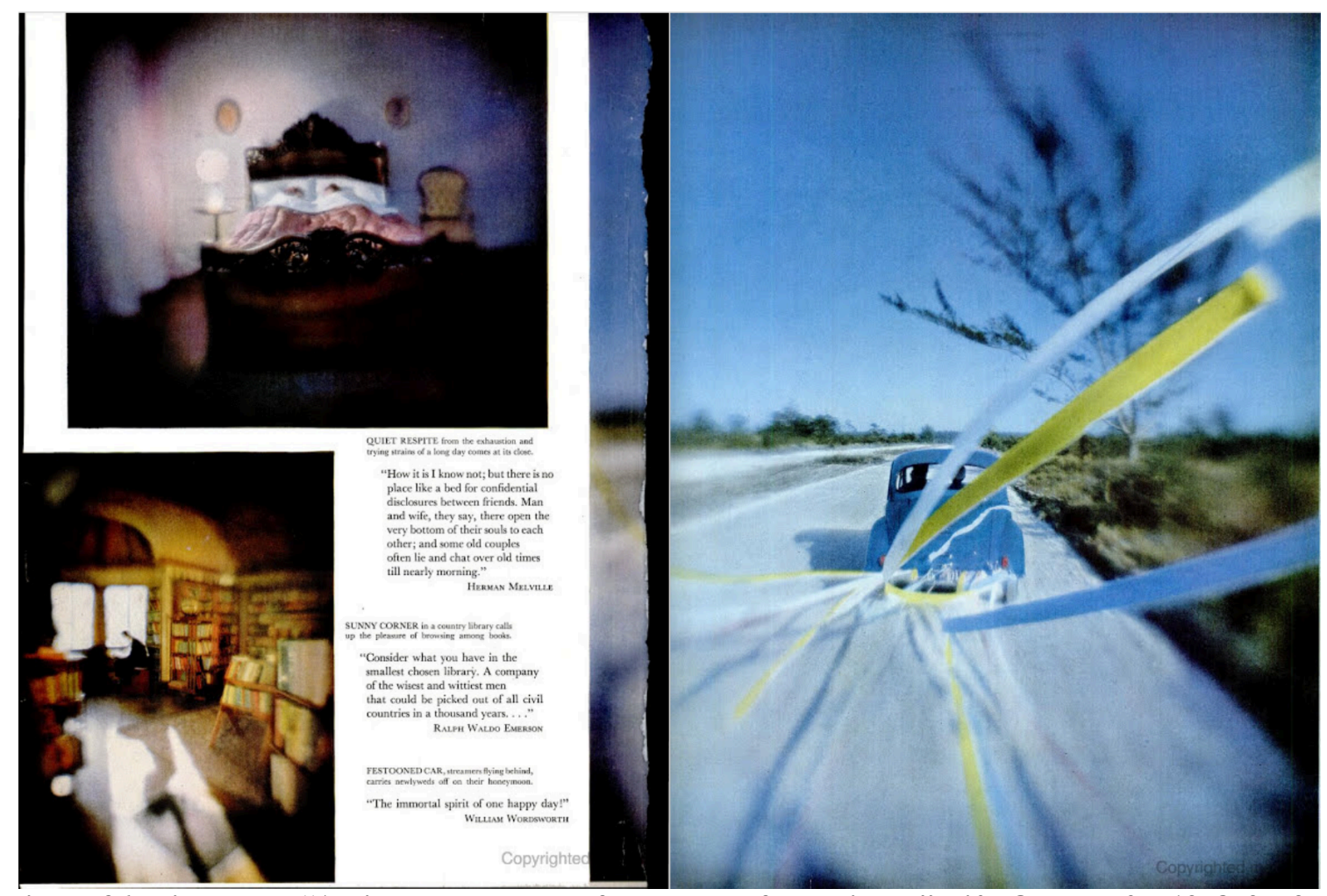

Figure 36: Nina Leen, “A Picture Portrayal of Moments of Happiness,” Life, October 27, 1958, 94-95.

The captions accompanying the photographs in "A Picture Portrayal of Moments of Happiness" are suited to a photographic essay about emotions, rather than a story concerning events or tangible subjects. Short descriptions of each image are accompanied by quotations borrowed from authors, poets, and philosophers. A single line of prose by the English poet William Wordsworth, for example, is paired with the photograph of the getaway car: "The immortal spirit of one happy day!" Without this line, the image feels eerie and unclear; with the help of Wordsworth's words, the sentiment of the couple becomes clear. Leen's use of gelatin filters in numerous stories demonstrates her versatility, inventiveness, and technological prowess, as well as her freedom to experiment during the latter half of her career at Life.

The photographic essays printed in the issues of Life directly before and after "A 
Picture Portrayal of Moments of Happiness" were more characteristic of the work typically published in the 'Photographic Essay' section. In "A Rare Picture Visit: The First Lady at Home," published on October 20, 1958, Edward Clark's photographs paint an intimate portrait of First Lady Marie "Mamie" Eisenhower's personal life-she tends to her grandchildren, plans events, and socializes with politicians' wives. On November 3, 1958, Life's photographic essay section featured two stories. The first was "Rainbow Realm of Tropic Insects," the third part of a series called 'Darwin's World of Nature' featuring photographs of critters in the Brazilian jungle by Dmitri Kessel, Rudolph Freund, and Edward Ross. The second essay, "Hypnosis: Out of Ancient Magic Comes a New Medical Tool," includes images by Philippe Halsman, George Du Maurier, Jon Brenneis, Albert Fenn, Stan Wayman, Thomas MacAvoy, Leonard McCombe, and Carl Mydans, as well as one photograph credited to the Brown Brothers agency. The presence of physical objects and subjects makes photographing the president's wife, insects, and a therapeutic procedure much more straightforward than photographing happiness, because the photographers were merely tasked with entering the vicinity of their subjects and using their cameras to capture their forms in a visually appealing manner.

Only the lead image of "Hypnosis," a photomontage by Halsman, is noticeably constructed. A man wearing a suit with rings orbiting his head hovers in the centre of the composition, with his head tilted back. The rings, his peaceful facial expression, and the surrealistically large heads looking down at him suggest the man has entered state of trance (Figure 37). The twenty-one photographs extending over the following five spreads are more literal than metaphorical, showing doctors giving, and patients receiving, treatments. This approach contrasts with that used by Leen in her essay "A Picture 
Portrayal of Moments of Happiness" because rather than capturing a pre-existing subject, she was required to construct images with her camera. Although sporadic, Life's use of symbolic or surreal photographs such as those by Leen and Halsman demonstrate the magazine's reliance on these images for both visual appeal and the elucidation of immaterial subject matter. Leen's photographs explaining happiness are expressive and affecting, rather than illustrative and veracious, yet still emblematic of Life's corpus of photojournalism, which includes visual experimentation as well as clear-cut, representative records.

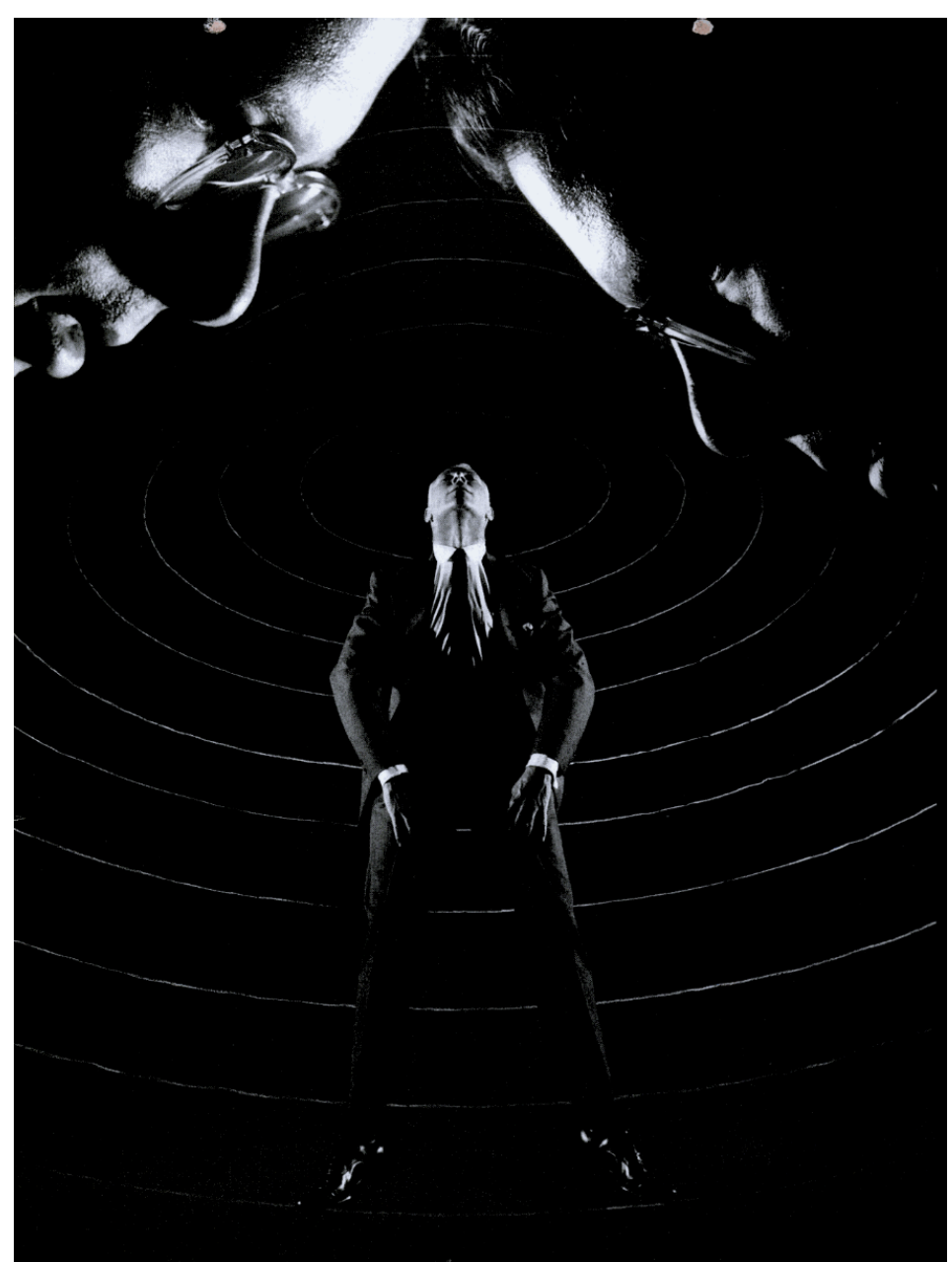

Figure 37: Philippe Halsman, "Hypnosis: Out of Ancient Magic Comes a New Medical Tool," Life, November 3, 1958, 112. 


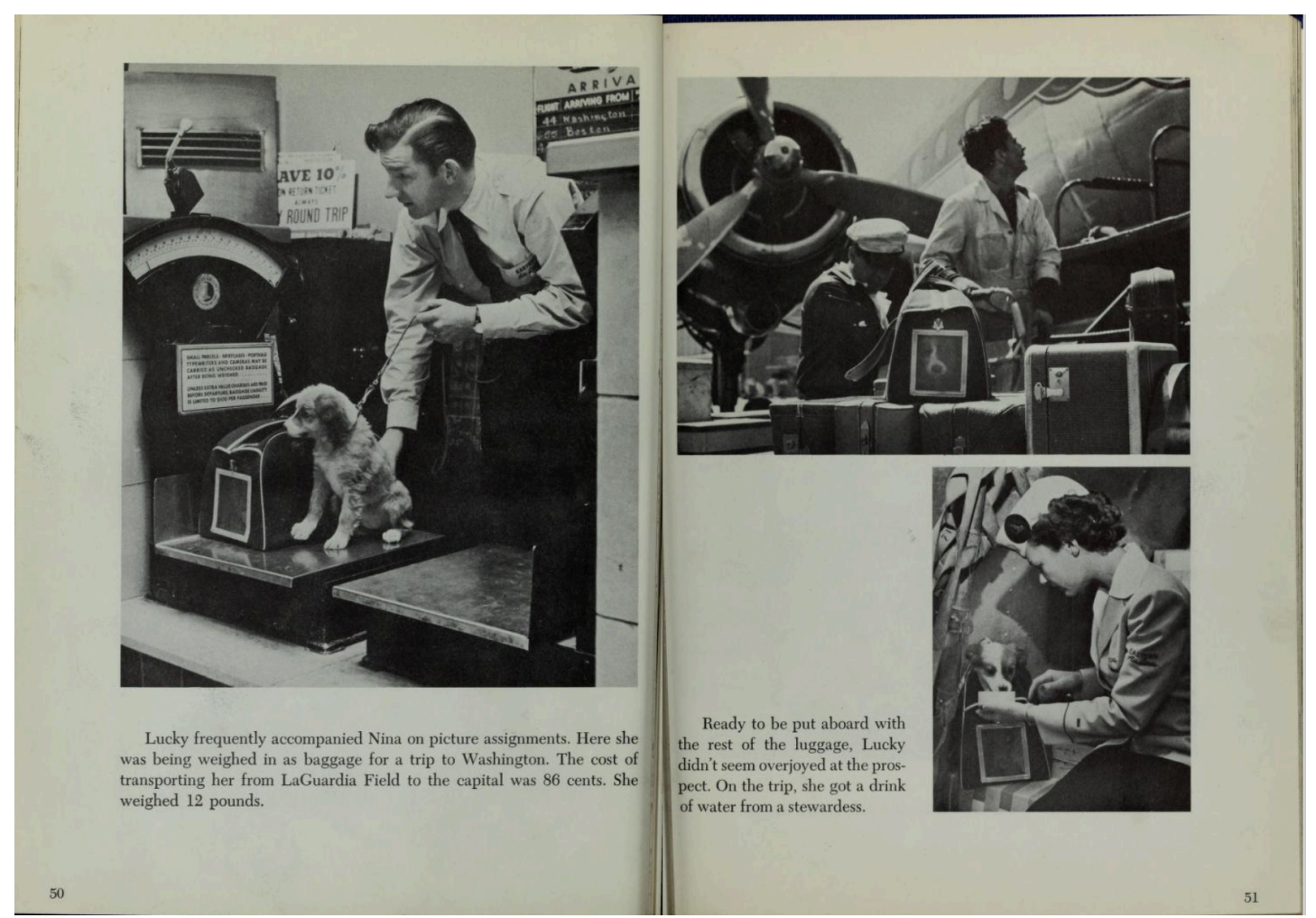

Figure 38: Nina Leen and Ray Mackland, Lucky, the Famous Foundling (New York, A. A. Wyn, 1951), 50-51.

Leen found other applications for her photographs outside the pages of Life magazine. Between 1951 and 1981 she created fifteen photobooks, predominantly using images made for Life. Ten of them featured animal photographs, including one about Leen's own dog, Lucky, with text by Ray Mackland (Figure 38). Of the others, Taking Pictures was an instructional book on photography for children, and Sandikins was a children's fiction story illustrated by Leen's photographs of skate fish-egg cases. The remaining three books employed her photographs in a conceptual manner. For the latter she developed a method of artistic expression by recontextualizing existing photographs, pairing them with texts that offered her own commentary on the human condition. Women, Heroes and a Frog (1970) and Love, Sunrise and Elevated Apes (1974) measured $8 \times 8$ inches, while Images of Sound is slightly larger. These three soft-cover 
books are filled with black and white images; the small size of the books makes the act of reading them more intimate and personal, compared to the experience of flipping through the oversized pages of a copy of Life. The structures of all three follow a standard formula: each page typically contains a single photograph paired with a line or verse composed by an intellectual.

The first image in Leen's 1974 book Love, Sunrise, and Elevated Apes was originally created for "Moments of Happiness Portrayed in Pictures." In order to evoke the concept of desire, Leen paired this formerly unpublished image with an accompanying quote by Thomas Lovell Beddoes: "If there were dreams to sell / What would you buy?" Seven of the first ten images in another book, Women, Heroes, and a Frog, were created using her gelatin technique, with others appearing sporadically throughout the rest of the book. These images also appear in another of Leen's conceptual photobooks, Images of Sound, published in 1977, the photographer reviewed all of her past work for Life in order to choose images that evoked sensations of sound (Figure 39). ${ }^{125}$ Leen's repeated use of images created with her gelatin technique in these books emphasizes the photographer's commitment to her own artistic expression.

The same photograph of a marital honeymoon car that originally appeared in "A Picture Portrayal of Moments of Happiness" was reproduced in Women, Heroes, and a Frog (Figure 40), but the image that once functioned as an illustration of the concept of happiness was paired with a passage by Socrates that poked fun at the concept of marriage, "By all means marry: if you get a good wife you'll become happy; if you get a bad one, you'll become a philosopher, ${ }^{, 26}$ providing the photograph a renewed sense of

\footnotetext{
${ }^{125}$ FYI, February 6, 1978, New-York Historical Society, The Time Inc. Archives.
}

${ }^{126}$ Nina Leen, Women, Heroes, and a Frog (New York: W.W. Norton, 1970), 7. 
irony. The same approach was used on the opposite page of the spread to drive the point home: the quotation beside a photograph of a newlywed couple reads "It's a funny thing that when a man hasn't got anything on earth to worry about, he goes off and gets married." ${ }^{127}$ Without the text from the original photographic essay explaining her intention to 'distil' happiness into photographs, Leen directed-but did not completely restrict-readers' interpretations of the photographs in Women, Heroes, and a Frog.
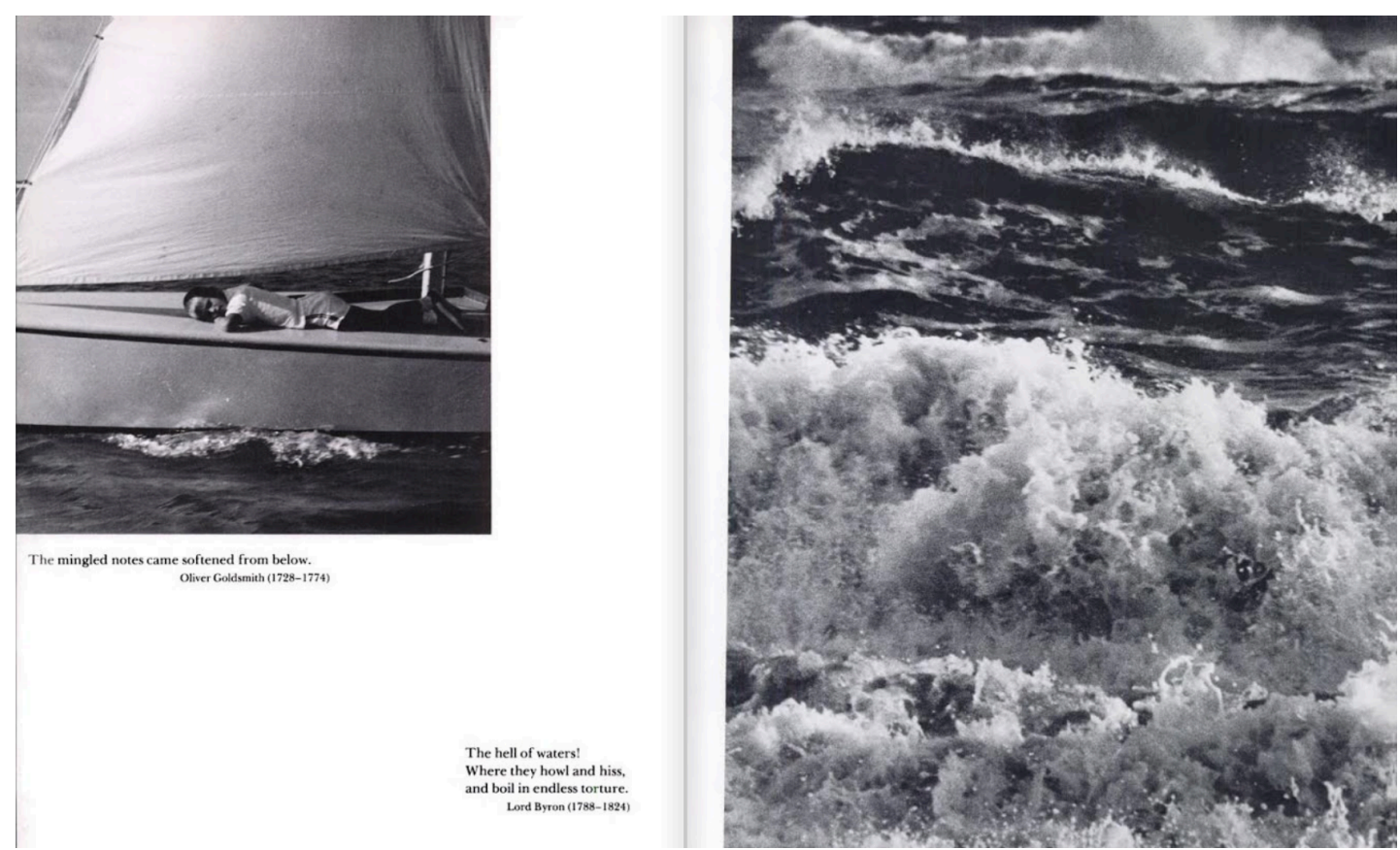

Figure 39: Nina Leen, Images of Sound (New York: Norton, 1977), 5-6.

Elizabeth Edwards once wrote that "an object cannot be fully understood at any single point in its existence, but rather should be understood as belonging in a continuing process of meaning, production, exchange and usage." ${ }^{\prime 28}$ If this is true, then the reproduction of Leen's photographs in her self-published photobooks is revealing. Her fondness for these photographs and their expressive qualities is divulged through their

\footnotetext{
${ }^{127}$ Nina Leen, Women, Heroes, and a Frog (New York: W.W. Norton, 1970), 6.

${ }^{128}$ Elizabeth Edwards, "Material beings, Objecthood and Ethnographic Photographs," Visual Studies 17, no. 1 (2002): 68.
} 
reuse: the next chapter in the social biographies of these images is signaled by their inclusion in these books. Separated from their original contexts, these images were removed from the realm of photojournalism; published for the first time without input from Life editors, they functioned in an artistic manner. While the photographers who sought to evade the control of magazines' editorial staff by founding the agency Magnum Photos, Inc. primarily created images for the press, "at the same time they were seeking other outlets that would allow them greater freedom." ${ }^{129}$ Much like these photojournalists, Leen turned to book publishing because it "brought increased control over their output" and offered "a time frame freed from the hectic pace of the topical." 130 After decades of handing her images over to Life's editors, Leen chose to take on the role of editor herself, exerting the control over layouts and captioning that a photojournalist typically lacks, and using these books to reconceive her photographs as art.
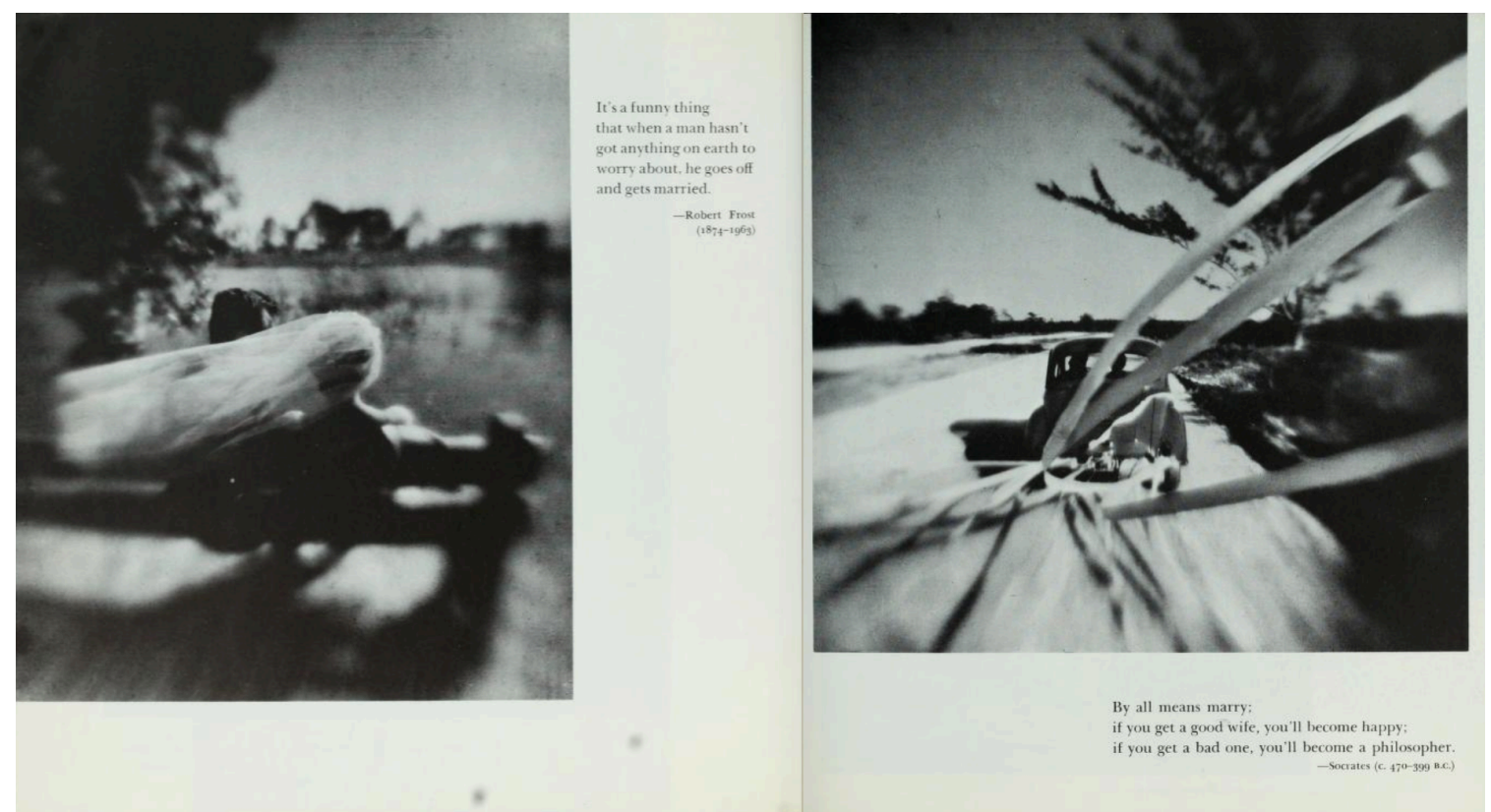

Figure 40: Nina Leen, Women, Heroes, and a Frog (New York: W.W. Norton, 1970), 6-7.

\footnotetext{
${ }^{129}$ Gervais, The Making of Visual News, 149.

${ }^{130}$ Ibid.
} 


\section{5. "Batwoman"}

Leen had been passionate about animals from a young age, having owned exotic pets including monkeys, snakes, and amphibians as a child, and expressing nostalgia while reminiscing to Loengard about her days spent roaming the Bronx Zoo with her first Rolleiflex. ${ }^{131}$ Her first major story concerning animals, "Dazzling Collection of Pheasants from Asia is Assembled in North Carolina," appeared in Life magazine on October 15, 1956. This story was followed by "Zoo Season in the Sun," a photographic essay published on April 22, 1957, and two more essays, "Strange World of Snakes" on March 1, 1963 and "The Strange World of Bats" on March 29, 1968. In the second half of her career at Life she was able to use her photographic aptitude - a combination of technical and artistic sensibilities - to produce more wildlife photography. The most rewarding implication of Leen's newly achieved autonomy was her ability to produce the photographs she had always dreamed of creating: the expressive, experimental photographs previously described represented one outcome; impactful animal photography embodied another.

"The Strange World of Bats" was spread out over eleven pages, ten of which featured colour images (Figure 41). This issue's table of contents was divided into two parts: 'Opinion and Comment' and 'The Week's News and Features', with Leen's essay falling in the second category. "The Strange World of Bats" was not designated a photographic essay in the manner previously employed by Life, because "as the 1950s wore on, segmentation of the contents gradually lost its relevance, and long photographic

\footnotetext{
131 "Unchecked and Uncorrected Transcript of Interview with Nina Leen" by John Loengard, interview, New-York Historical Society, The Time Inc. Archives, January 14, 1992, 4.
} 
series began to find their way into other sections." ${ }^{\prime 132}$ In the absence of the label 'Photographic Essay' above the title of her piece, readers needed to rely on the 'Editor's Note' on the right side of the page for more information about the story, in which managing editor George P. Hunt used the word 'essay' multiple times to describe "The Strange World of Bats." In the first paragraph Hunt wrote, "In this week's essay, Nina shows that there is real élan and elegance in such an improbable subject as bats." $" 133$

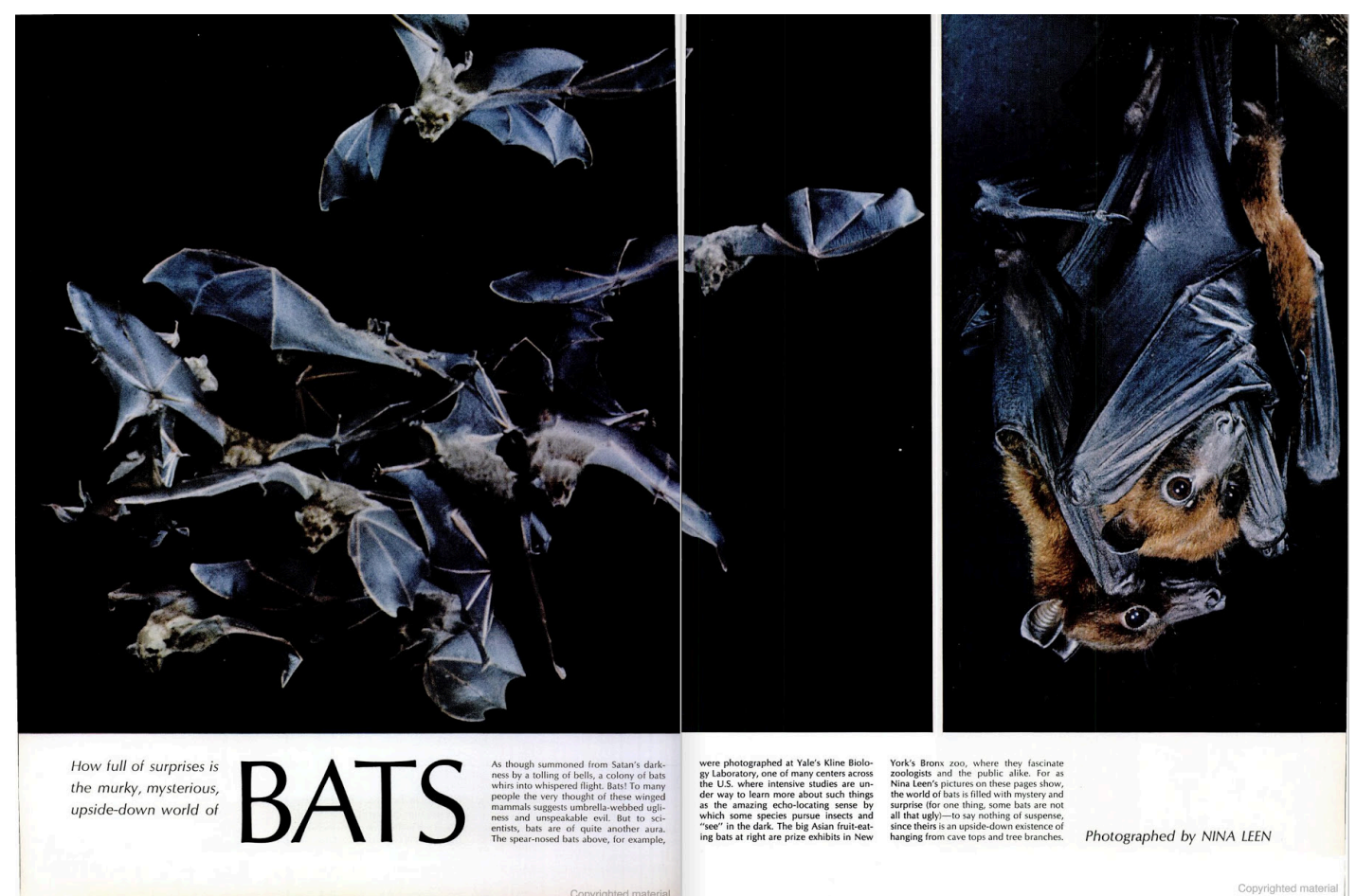

Figure 41: Nina Leen, “The Strange World of Bats," Life, March 29, 1968, 52-53.

Leen's photographs were accompanied by very little copy, and would have immediately captivated readers who had flipped the page only to find something unexpected. The first spread includes two photographs: a group of bats in flight on the

\footnotetext{
${ }^{132}$ Gervais, The Making of Visual News, 148.

${ }^{133}$ George P. Hunt, "Discovering the Beauty of Bats," Life, March 29, 1968, 3.
} 
left and a close-up shot of two bats hanging upside down on the right. Four photographs were arranged over the next two pages, each showing bats in action-they eat, transport prey, and fight. The third spread shows a large image of a spotted bat baring its teeth that covered most of the right page and bled into the left. According to the essay's text, the breed is "so elusive that it has probably never heretofore been photographed." ${ }^{134} \mathrm{~A}$ smaller image of the same bat on the left-hand page showcases the same species' enormous ears, with photographs of bats swimming and devouring a scorpion below. The next spread features a series of images depicting a fishing bat in action, as it flies near the surface of a body of water, dips its claw below, catches a fish, places its prey in its mouth, and flies off (Figure 42). The following two pages follow a similar structure as the first spread, with one close-up image revealing the details of three bats' faces, and the other depicting mother bats nursing countless babies.

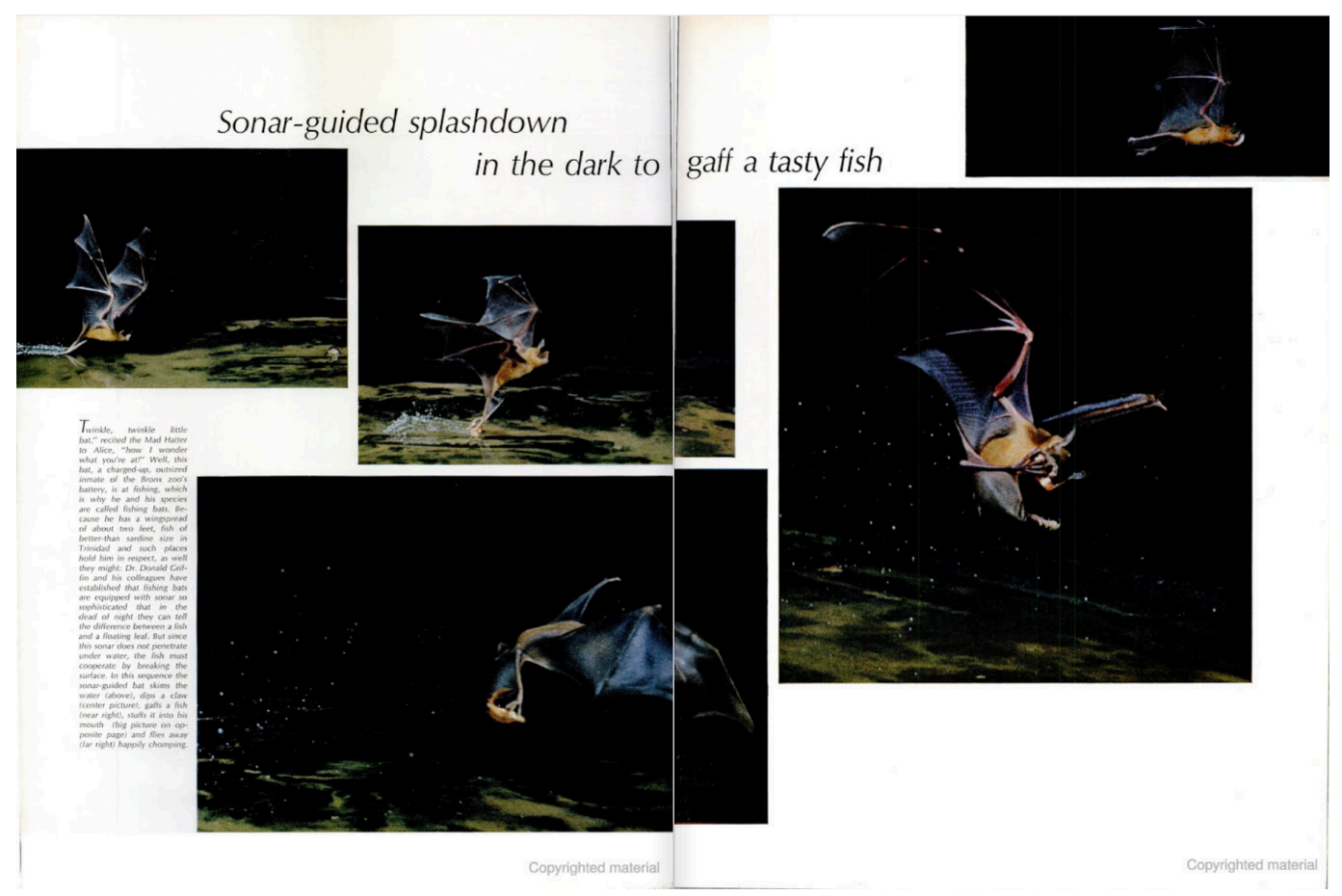

Figure 42: Nina Leen, “The Strange World of Bats,” Life, March 29, 1968, 58-59.

134 “The Strange World of Bats," Life, March 29, 1968, 56-57. 
No advertisements interrupt the first ten pages of Leen's essay. The first break in her images was a full-page spread promoting the Chevrolet II Nova, which directly follow the first five colour spreads. The next spread includes a single page advertising Rock of Ages memorials on the left, and the final page of the essay on the right, which features the bulk of the essay's text. The last page of the essay is dedicated almost entirely to text, save for a single black and white photograph along the bottom.

The disruption caused by three consecutive pages of advertisements allowed readers interested only in the images to flip past the text-heavy final page, through the next three pages of advertisements, until they reached photographs of Jane Fonda in her then-new movie, Barbarella. More invested individuals, on the other hand, had the opportunity to learn more about the strange creatures photographed by Leen. The separation of image and text, and the primacy of the former, demonstrates the editors' belief that the educational potential of Leen's photographs was secondary to their aesthetic appeal. The dark environments and their demand for high speed equipment resulted in unexpected formal effects (Figure 43), leading readers to recognize Leen's photographs as images only an adept maker could produce. While "The Strange World of Bats" was rich in informative content, as was Life in general, the magazine relied primarily on visually appealing images to captivate its readers.

After approaching an unspecified editor with the idea that she would pursue a story about bats, "they said no . . . if they would do a story, they would assign a science photographer to do it because I wouldn't be able to do it." ${ }^{135}$ She nonetheless began to photograph bats, relying on her own time and money to do so-resources that would

135 "Unchecked and Uncorrected Transcript of Interview with Nina Leen" by John Loengard, interview, New-York Historical Society, The Time Inc. Archives, January 14, 1992, 29. 
have been far too scarce for the photographer a decade earlier. Some time after she had begun photographing her "flying kittens," ${ }^{36}$ as she affectionately named them, another unidentified Life editor learned of her ploy and asked to see the photographs. Not only was he impressed, but he agreed to publish the story. Hunt's 'Editor's Note' entitled "Discovering the Beauty of Bats" naturally fails to mention the magazine's initial skepticism about Leen's ability to create this story, instead describing the difficulties faced by the photographer: "For the last picture in the essay ... Dr. Jerry Winkler of the Public Health Service taped her into a special jumpsuit to protect her from falling mites and bugs and led her underground." 137

The resulting photographs paused time for Life's readers, allowing them to examine the rapid motions and subtle gestures of an animal that typically flickers out of sight in the blink of an eye. Lighted figures arranged on dark backgrounds even resemble negative images before they are reversed for printing, creating a mystifying effect when encountered on the pages of a magazine (Figures 43-45). One image shows a single bat with its wings spread, perched atop an illuminated cactus and drinking from its fruit (Figure 45). While the image is a colour photograph, the overall tone is subdued by the combination of a dark environment and bright flash, immediately bringing the bat's deep red tongue to the attention of the reader. Rather than submit to the complications involved with photographing bats, Leen prevailed by producing photographs that were simultaneously visually engaging and scientifically accurate.

\footnotetext{
${ }^{136}$ George P. Hunt, “Editor's Note: From Fighting Turtles to Flying Kittens,” Life, July 29, $1966,3$.

${ }^{137}$ George P. Hunt, “Editor's Note: Discovering the Beauty of Bats," Life, March 29, 1968, 3.
} 

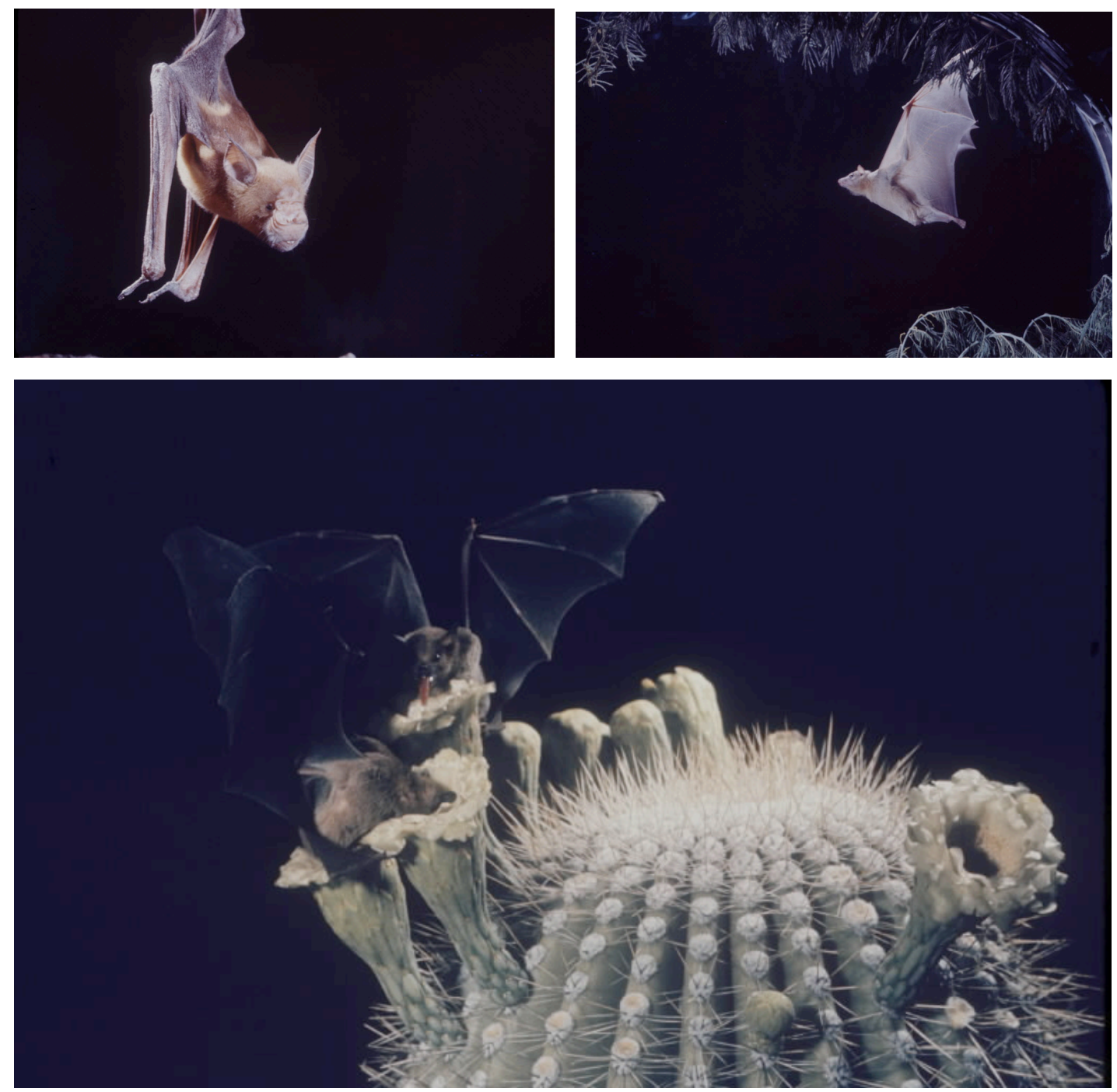

Figures 43-45: Nina Leen, "The World of Bats," digital reproductions from colour transparencies, 1968. Life Photo Collection, Google Arts and Culture.

Leen's stories on bats and snakes both benefited from a three-day camera clinic

on the use of stroboscopic light in solving lighting problems. The 1947 clinic was held in the studio of Gjon Mili-another experimental photographer, who pioneered the use of stop motion photography and stroboscopic lighting. ${ }^{138}$ An FYI article informed other Life photographers that this lighting technique would be useful when shooting fashion shows,

\footnotetext{
${ }^{138}$ FYI, August 18 1947, New-York Historical Society, The Time Inc. Archives; Yin-Ren Chang and Martin Richardson, "Drawing Lines with Light in Holographic Space," Journal of Physics: Conference Series 415, no. 1 (2013): 3.
} 
but Leen chose to put it to use in her animal studies instead. In order to achieve the nearly impossible task of photographing a cobra during the split second in which its tongue is ejected from its mouth, Leen "used a rapid sequence camera which could take up to 20 frames per second, synchronized to speed lights" (Figure 46) ${ }^{139}$ Leen's awareness of the possibilities of technology in adapting lighting and camera speed was also applied five years later, while photographing her 'flying kittens':

The motor-drive on her camera was not quite fast enough to guarantee a good shot of the bat as it passed by the lens of the camera, so she sat down one day with the maker of the Hulcher camera and his designers and explained exactly what she wanted in a camera. They decided that her requests were possible, and many months later a camera was delivered to her which was able to shoot with strobelights up to 20 synchronized exposures in one second. ${ }^{140}$

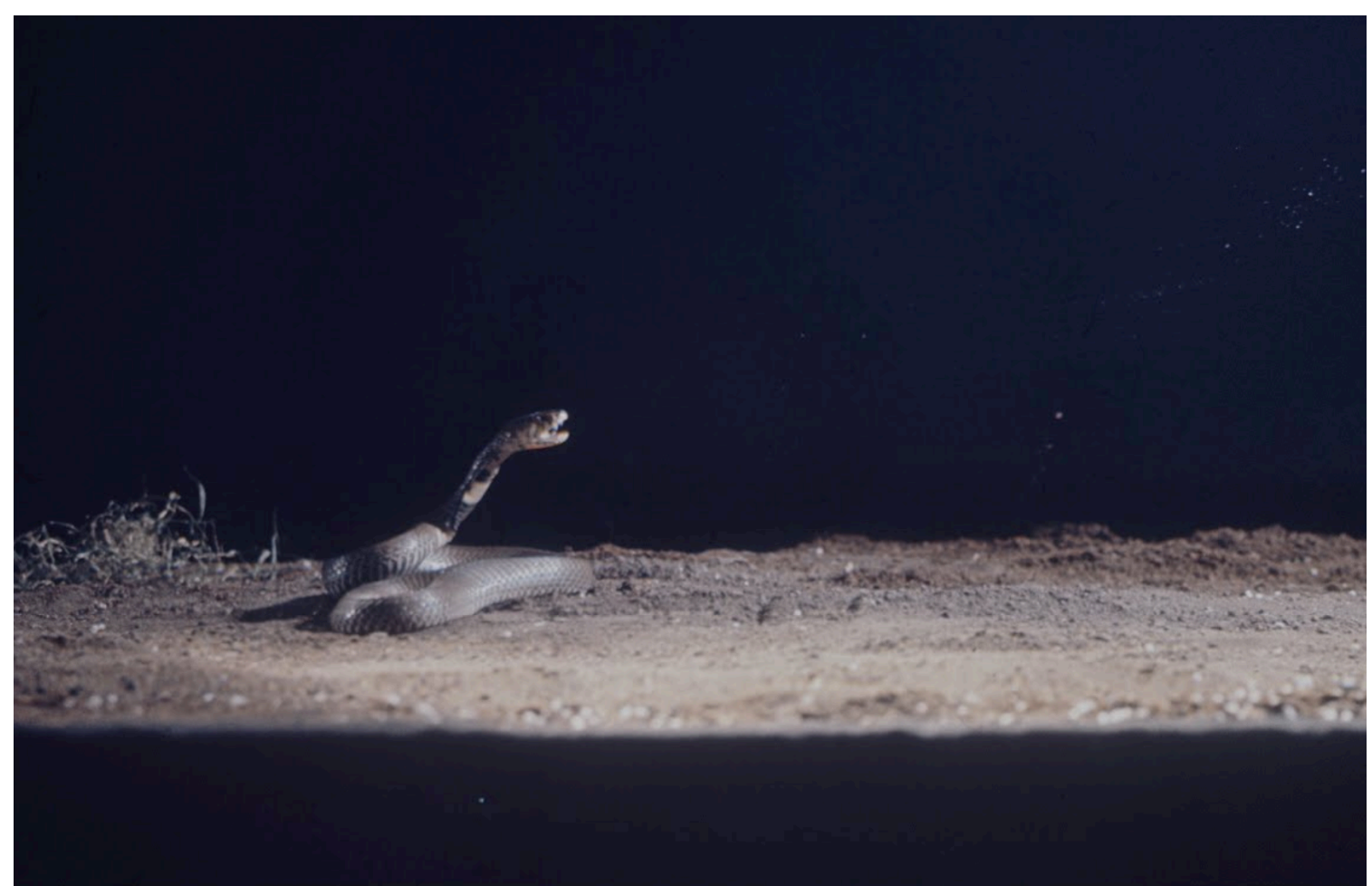

Figure 46: Nina Leen, “African Spitting Cobra,” colour transparency, 1963. Life Photo Collection, Google Arts and Culture.

139 "Editor's Note: A Snake Charmer With a Camera," Life, March 1, 1963, 3.

140 "Nina Leen," FYI, New-York Historical Society, The Time Inc. Archives, 1969. A fellow Life photographer also used a modified Hulcher camera to create photographs of athletes in action for Life and Sports Illustrated in the 1970s: Jakob Schiller, "Beloved High-Speed Film Camera Faces Extinction," Wired, August 22, 2012, https://www.wired.com/2012/08/hulcher-high-speed-cameras/. 
A July 1969 newsletter addressed to Life staff described Leen's bat essay as her finest one to date. The story prompted an exhibition of her bat photography at the Bronx Zoo, ${ }^{141}$ and The World of Bats, ${ }^{142}$ a large, diagram- and image-heavy, textbook-style publication, was created in collaboration with Yale biologist and bat expert Alvin Novick using the same images. ${ }^{143}$ According to some critics, Leen's pictorial contribution to The World of Bats was more impressive than Novick's scientific expertise. A New York Times review of the book declared, "What really counts ... is the photography. The pictures, taken by Nina Leen, over three years of devoted batstalking, are marvelous, and it is not at all surprising that on the title page Miss Leen takes precedence over Dr. Novick." 144 "The Strange World of Bats" signified the pinnacle of Nina Leen's foray into animal photography.

In the introduction to The World of Bats, Leen noted her astonishment upon realizing that most bookstores she visited while conducting research for her project "had never even heard of a book about bats," so she went on to resolve the matter. ${ }^{145}$ A New York-based specialist in high school textbooks, Holt, Rinehart and Winston, and a Swiss printer of fine art books, Edita Lausanne, published The World of Bats simultaneously. According to Leen, the book would have been published elsewhere had it not been for a squabble between the American and Swiss publishers. The Swiss publisher stopped publishing the book, and he had ... phone calls from Japan, and France ... phone calls from five different countries, who wanted a certain amount

\footnotetext{
141 “Batwoman," FYI, New-York Historical Society, The Time Inc. Archives, July 11, 1969.

${ }^{142}$ Alvin Novick and Nina Leen, The World of Bats (Lausanne: Edita, 1969).

${ }^{143}$ Los Angeles Times Staff Writer, "Alvin Novick, 79; Was Expert on Bats, Led Efforts to Fight AIDS," Los Angeles Times, April 24, 2005, http://articles.latimes.com/2005/apr/24/local/me-novick24.

${ }^{144}$ New York Times, "Book Review: The World of Bats," New-York Historical Society, The Time Inc. Archives, May 10, 1970.

${ }^{145}$ Alvin Novick and Nina Leen, The World of Bats (New York: Holt, Rinehart, and Winston 1969), 8.
} 
of these books. But it didn't work because, see the book, the big book, the publishing, would cost a lot of money and the American publisher didn't want to give it, I guess. It's a shame. ${ }^{146}$

Even in the heavy, academic-style book published by Holt, Rinehart and Winston, filled with brilliant colour images and diagrams describing the behaviour of bats, it is clear that Leen's understanding of art informed her work. "In art," she asserted in the book's text, "it is an established tradition that when bats are pictured a full moon is shown in the night sky behind them."147 Leen desired for the general public to understand these mysterious animals, and thanks to Life she was able to use her photographic aptitude - and eventually the magazine's resources - to achieve this aim. Considering "there was less known about the behavior of bats at that time than about the faraway moon," this project was no easy undertaking. ${ }^{148}$

Leen waited patiently for over fifteen years between arriving in America and creating in-depth photographic studies of animals. The resources and skills acquired by her throughout her career at Life were crucial to the success of these stories. Working for Life not only provided Leen with the necessary financial resources, but also an essential education: years of practice and personal development, as well as invitations to attend structured events facilitated by the magazine, expanded her knowledge of photography and allowed her to use this information to create striking photographs.

\footnotetext{
146 "Unchecked and Uncorrected Transcript of Interview with Nina Leen" by John Loengard, interview, New-York Historical Society, The Time Inc. Archives, January 14, 1992, 30.

${ }^{147}$ Novick and Leen, The World of Bats, 167.

148 “Nina Leen," FYI, New-York Historical Society, The Time Inc. Archives, July/August 1979.
} 


\section{Conclusion}

Leen was not a particular fan of Henri Cartier-Bresson. When speaking to John Loengard about Cartier-Bresson's photographs, she explained, "Some pictures bothered me because I thought that if he would crop it differently, it would be a good picture. But because he did not crop it, there were things which took my attention because they bothered me, and I didn’t consider it a good picture." ${ }^{149}$ Leen's working practices were certainly at odds with Cartier-Bresson's belief that "if you start cutting or cropping a good photograph, it means death to the geometrically correct interplay of proportions." ${ }^{150}$ The former embraced photography's possibilities of manipulation and construction that the latter in part rejected.

The claim that Cartier-Bresson's work "synthesizes two major traditions of twentieth century photography, namely, photojournalism and fine art photography,"151 however, holds true for Leen. The synthesis of reportage and aesthetic is precisely what Life relied on to fill its pages, and was the main reason Leen was indispensable to the magazine. In a 1936 memorandum, Luce compared feature stories with news coverage, explaining "They don't conflict with each other; they help each other. Danger is that we go fuzzy in confusing them. Each is a different kind of pictorial journalism. Together they make a great weekly." 152 Depictions of war and newsworthy historical events are nearly nonexistent in Leen's photographs, and yet she was no less of a photojournalist

\footnotetext{
149 "Unchecked and Uncorrected Transcript of Interview with Nina Leen" by John Loengard, interview, New-York Historical Society, The Time Inc. Archives, January 14, 1992, 9.

${ }^{150}$ Henri Cartier-Bresson, The Mind's Eye: Writings on Photography and Photographers (New York: Aperture, 1999), 34.

${ }^{151}$ Sarah Hermanson, "Henri Cartier-Bresson" MoMA 3, no. 6 (September 2000): 31.

${ }^{152}$ Henry Luce, "Redefinition of Life - Part I," memorandum, The Time Inc. Archives, July 6, 1936, 2.
} 
than Margaret Bourke-White or W. Eugene Smith. Leen was also able to publish prolifically when not working on in-depth stories for the magazine during the first half of her career. As a result, her oeuvre represents a collection of the varied photojournalism published in Life between 1940 and 1972.

Other than this thesis, Leen's work has received no academic attention since her death in 1995, and interest from the commercial art world materialized only recently. Not only has the immense quantity of photographs produced by Leen in the service of Life's requisite soft stories been disregarded, but her work defies straightforward categorization, which is inconvenient for potential historians seeking to establish her place within the history of photojournalism. Leen's photography is multifarious, encompassing everything from architecture and entertainers to local politics and faraway royalty. It does not resemble the recognized archetypes of photojournalism - the shocking, the disturbing, and the newsworthy. Her images are often creative and constructed, two factors not typically associated with the genre. Life's efforts to market Nina Leen in a playful manner-exaggerating her gender even while she simultaneously overcame its supposed limitations - contributed to her lack of enduring prestige. Her photographic body of work also traversed discursive spaces, or, as Rosalind Krauss put it, "separate domains of culture," 153 including the gallery wall, the artistic photobook, the scientific textbook, and the mass-produced, illustrated, general news magazine.

While the hurdle Werner Wolff faced in becoming part of the canon of photojournalism was his lack of distinctive style, Leen's ultimate downfall was her multifarious oeuvre. The images now regarded as iconic are not characteristic of most of

\footnotetext{
${ }^{153}$ Rosalind Krauss, "Photography's Discursive Spaces: Landscape/View," in Art Journal 42, no. 4 (Winter 1982): 311 .
} 
the photographs she created. This varied body of work, however, is what allowed Leen to maintain her prized post at the magazine for thirty-two years. Leen contributed to Life's mission to "reveal . . . the nature of the dynamic social world in which we live," 154 through photographs showing the everyday, the humorous, and the fashionable.

Having hired only six women throughout the course of its thirty-six-year run, Life was not recognized for its women staff photographers, making Leen's position all the more precarious. Yet Leen's relationship with Life magazine was symbiotic: the photographer's work was as invaluable to the magazine as the magazine was invaluable to her. Life offered Leen financial independence soon after emigrating from Europe, and in return she contributed to the success of the magazine by providing copious images that promoted fads and lifestyles, and that entertained - and sometimes even amazed - its readers. For Leen, and likely for other photographers of her stature, Life acted as an incubator. The magazine provided job security for someone willing to work hard and adapt to its needs, while allowing Leen the chance to learn, experiment, and ultimately express herself through photography.

${ }^{154}$ Henry Luce, “A Prospectus for a New Magazine,” 1936. 


\section{Appendix A: Sections Appearing in Life Magazine's Table of Contents}

\begin{tabular}{|l|l|}
\hline \multicolumn{1}{|c|}{$\begin{array}{c}\text { Sections in Which Leen's Photographs Were } \\
\text { Published }\end{array}$} & $\begin{array}{l}\text { Sections Not Featuring Leen's Photographs } \\
\text { (sample from 1945 \& 1950) }\end{array}$ \\
\hline Animals & Adventure \\
\hline Archaeology & Agriculture \\
\hline Architecture & Anthropology \\
\hline Art & Army \& Navy \\
\hline Article(s)/Article of the Week & Aviation \\
\hline Better Living & Ballet \\
\hline Books & Birds \\
\hline Business & Business and Finance \\
\hline Close-Up(s) & Christmas Section for Children \\
\hline Education & Dance \\
\hline Entertainment & Drama \\
\hline Fashion & Food \\
\hline Gallery & Handicrafts \\
\hline Horticulture & Housing \\
\hline Ideas in Houses & Industry \\
\hline Letters to the Editor(s)/Pictures to the Editor(s) & Military Affairs \\
\hline LIFE's Garden News & Nightclubs \\
\hline LIFE's Girls & Poultry \\
\hline LIFE's Pictures & Sports \\
\hline LIFE's Reports & Summer Theater \\
\hline Medicine & Transportation \\
\hline Miscellany & Radio \\
\hline Modern Living & \\
\hline Movies & \\
\hline Music & \\
\hline Natural History & \\
\hline Nature & \\
\hline Other Departments & \\
\hline Party & \\
\hline People & \\
\hline Photographic Essay(s)/Pictorial Essay(s) & \\
\hline Postwar Living & \\
\hline Religion & \\
\hline Science & \\
\hline Speaking of Pictures & \\
\hline Spotlight & \\
\hline Television & \\
\hline The Major Article & \\
\hline The Week's Events & \\
\hline Theater & \\
\hline To See America & \\
\hline Travel & \\
\hline War Living & \\
\hline
\end{tabular}




\section{Appendix B: List of 373 Life Issues Featuring Nina Leen's Photography}

\begin{tabular}{|c|c|c|c|}
\hline Year & Day & Month & Issue \\
\hline 1940 & 1 & 4 & 814 \\
\hline 1940 & 20 & 5 & 821 \\
\hline 1940 & 15 & 7 & 903 \\
\hline 1940 & 18 & 11 & 921 \\
\hline 1941 & 16 & 6 & 1024 \\
\hline 1941 & 6 & 10 & 1114 \\
\hline 1941 & 3 & 11 & 1118 \\
\hline 1941 & 10 & 11 & 1119 \\
\hline 1941 & 1 & 12 & 1122 \\
\hline 1942 & 20 & 4 & 1216 \\
\hline 1942 & 11 & 5 & 1219 \\
\hline 1942 & 22 & 6 & 1225 \\
\hline 1942 & 24 & 8 & 1308 \\
\hline 1942 & 31 & 8 & 1309 \\
\hline 1942 & 5 & 10 & 1314 \\
\hline 1942 & 26 & 10 & 1317 \\
\hline 1942 & 14 & 12 & 1324 \\
\hline 1943 & 28 & 6 & 1426 \\
\hline 1943 & 19 & 7 & 1503 \\
\hline 1943 & 9 & 8 & 1506 \\
\hline 1943 & 23 & 8 & 1508 \\
\hline 1943 & 13 & 9 & 1511 \\
\hline 1943 & 27 & 9 & 1513 \\
\hline 1943 & 4 & 10 & 1514 \\
\hline 1943 & 18 & 10 & 1516 \\
\hline 1943 & 8 & 11 & 1519 \\
\hline 1944 & 24 & 1 & 1604 \\
\hline 1944 & 31 & 1 & 1605 \\
\hline 1944 & 21 & 2 & 1608 \\
\hline 1944 & 6 & 3 & 1610 \\
\hline 1944 & 3 & 4 & 1614 \\
\hline 1944 & 17 & 4 & 1616 \\
\hline 1944 & 22 & 5 & 1621 \\
\hline 1944 & 12 & 6 & 1624 \\
\hline 1944 & 3 & 7 & 1701 \\
\hline 1944 & 10 & 7 & 1702 \\
\hline 1944 & 17 & 7 & 1703 \\
\hline 1944 & 24 & 7 & 1704 \\
\hline 1944 & 14 & 8 & 1707 \\
\hline 1944 & 21 & 8 & 1708 \\
\hline 1944 & 4 & 9 & 1710 \\
\hline 1944 & 11 & 9 & 1711 \\
\hline 1944 & 18 & 9 & 1712 \\
\hline 1944 & 2 & 10 & 1714 \\
\hline 1944 & 9 & 10 & 1715 \\
\hline 1944 & 23 & 10 & 1717 \\
\hline
\end{tabular}




\begin{tabular}{|c|c|c|c|}
\hline 1944 & 30 & 10 & 1718 \\
\hline 1944 & 6 & 11 & 1719 \\
\hline 1944 & 11 & 12 & 1724 \\
\hline 1945 & 1 & 1 & 1801 \\
\hline 1945 & 8 & 1 & 1802 \\
\hline 1945 & 5 & 2 & 1806 \\
\hline 1945 & 5 & 3 & 1810 \\
\hline 1945 & 26 & 3 & 1813 \\
\hline 1945 & 2 & 4 & 1814 \\
\hline 1945 & 16 & 4 & 1816 \\
\hline 1945 & 23 & 4 & 1817 \\
\hline 1945 & 7 & 5 & 1819 \\
\hline 1945 & 21 & 5 & 1821 \\
\hline 1945 & 4 & 6 & 1823 \\
\hline 1945 & 11 & 6 & 1824 \\
\hline 1945 & 25 & 6 & 1826 \\
\hline 1945 & 2 & 7 & 1901 \\
\hline 1945 & 30 & 7 & 1905 \\
\hline 1945 & 13 & 8 & 1907 \\
\hline 1945 & 20 & 8 & 1908 \\
\hline 1945 & 3 & 9 & 1910 \\
\hline 1945 & 22 & 10 & 1917 \\
\hline 1945 & 29 & 10 & 1918 \\
\hline 1945 & 5 & 11 & 1919 \\
\hline 1945 & 19 & 11 & 1921 \\
\hline 1945 & 26 & 11 & 1922 \\
\hline 1945 & 3 & 12 & 1923 \\
\hline 1945 & 10 & 12 & 1924 \\
\hline 1945 & 17 & 12 & 1925 \\
\hline 1945 & 24 & 12 & 1926 \\
\hline 1945 & 31 & 12 & 1927 \\
\hline 1946 & 18 & 2 & 2007 \\
\hline 1946 & 1 & 4 & 2013 \\
\hline 1946 & 22 & 4 & 2016 \\
\hline 1946 & 6 & 5 & 2018 \\
\hline 1946 & 3 & 6 & 2022 \\
\hline 1946 & 10 & 6 & 2023 \\
\hline 1946 & 24 & 6 & 2025 \\
\hline 1946 & 22 & 7 & 2104 \\
\hline 1946 & 12 & 8 & 2107 \\
\hline 1946 & 26 & 8 & 2109 \\
\hline 1946 & 2 & 9 & 2110 \\
\hline 1946 & 23 & 9 & 2113 \\
\hline 1946 & 7 & 10 & 2115 \\
\hline 1946 & 14 & 10 & 2116 \\
\hline 1946 & 21 & 10 & 2117 \\
\hline 1946 & 4 & 11 & 2119 \\
\hline 1946 & 25 & 11 & 2122 \\
\hline 1946 & 23 & 12 & 2126 \\
\hline
\end{tabular}




\begin{tabular}{|c|c|c|c|}
\hline 1946 & 30 & 12 & 2127 \\
\hline 1947 & 27 & 1 & 2204 \\
\hline 1947 & 3 & 2 & 2205 \\
\hline 1947 & 24 & 2 & 2208 \\
\hline 1947 & 12 & 5 & 2219 \\
\hline 1947 & 19 & 5 & 2220 \\
\hline 1947 & 16 & 6 & 2224 \\
\hline 1947 & 14 & 7 & 2302 \\
\hline 1947 & 21 & 7 & 2303 \\
\hline 1947 & 4 & 8 & 2305 \\
\hline 1947 & 11 & 8 & 2306 \\
\hline 1947 & 1 & 9 & 2309 \\
\hline 1947 & 15 & 9 & 2311 \\
\hline 1947 & 22 & 9 & 2312 \\
\hline 1947 & 6 & 10 & 2314 \\
\hline 1947 & 13 & 10 & 2315 \\
\hline 1947 & 27 & 10 & 2317 \\
\hline 1947 & 1 & 12 & 2322 \\
\hline 1947 & 8 & 12 & 2323 \\
\hline 1947 & 29 & 12 & 2326 \\
\hline 1948 & 12 & 1 & 2402 \\
\hline 1948 & 9 & 2 & 2406 \\
\hline 1948 & 8 & 3 & 2410 \\
\hline 1948 & 15 & 3 & 2411 \\
\hline 1948 & 22 & 3 & 2412 \\
\hline 1948 & 12 & 4 & 2415 \\
\hline 1948 & 19 & 4 & 2416 \\
\hline 1948 & 26 & 4 & 2417 \\
\hline 1948 & 10 & 5 & 2419 \\
\hline 1948 & 24 & 5 & 2421 \\
\hline 1948 & 31 & 5 & 2422 \\
\hline 1948 & 21 & 6 & 2425 \\
\hline 1948 & 26 & 7 & 2504 \\
\hline 1948 & 6 & 9 & 2510 \\
\hline 1948 & 4 & 10 & 2514 \\
\hline 1948 & 1 & 11 & 2518 \\
\hline 1948 & 15 & 11 & 2520 \\
\hline 1948 & 29 & 11 & 2522 \\
\hline 1948 & 13 & 12 & 2524 \\
\hline 1949 & 3 & 1 & 2601 \\
\hline 1949 & 7 & 2 & 2606 \\
\hline 1949 & 28 & 2 & 2609 \\
\hline 1949 & 7 & 3 & 2610 \\
\hline 1949 & 21 & 3 & 2612 \\
\hline 1949 & 28 & 3 & 2613 \\
\hline 1949 & 4 & 4 & 2614 \\
\hline 1949 & 11 & 4 & 2615 \\
\hline 1949 & 9 & 5 & 2619 \\
\hline 1949 & 16 & 5 & 2620 \\
\hline
\end{tabular}




\begin{tabular}{|c|c|c|c|}
\hline 1949 & 23 & 5 & 2621 \\
\hline 1949 & 30 & 5 & 2622 \\
\hline 1949 & 6 & 6 & 2623 \\
\hline 1949 & 25 & 7 & 2704 \\
\hline 1949 & 1 & 8 & 2705 \\
\hline 1949 & 8 & 8 & 2706 \\
\hline 1949 & 15 & 8 & 2707 \\
\hline 1949 & 22 & 8 & 2708 \\
\hline 1949 & 29 & 8 & 2709 \\
\hline 1949 & 12 & 9 & 2711 \\
\hline 1949 & 19 & 9 & 2712 \\
\hline 1949 & 26 & 9 & 2713 \\
\hline 1949 & 3 & 10 & 2714 \\
\hline 1949 & 17 & 10 & 2716 \\
\hline 1949 & 7 & 11 & 2719 \\
\hline 1949 & 5 & 12 & 2723 \\
\hline 1949 & 19 & 12 & 2725 \\
\hline 1950 & 2 & 1 & 2801 \\
\hline 1950 & 9 & 1 & 2802 \\
\hline 1950 & 6 & 2 & 2806 \\
\hline 1950 & 20 & 2 & 2808 \\
\hline 1950 & 24 & 4 & 2817 \\
\hline 1950 & 1 & 5 & 2818 \\
\hline 1950 & 8 & 5 & 2819 \\
\hline 1950 & 15 & 5 & 2820 \\
\hline 1950 & 29 & 5 & 2822 \\
\hline 1950 & 19 & 6 & 2825 \\
\hline 1950 & 3 & 7 & 2901 \\
\hline 1950 & 10 & 7 & 2902 \\
\hline 1950 & 31 & 7 & 2905 \\
\hline 1950 & 14 & 8 & 2907 \\
\hline 1950 & 11 & 9 & 2911 \\
\hline 1950 & 25 & 9 & 2913 \\
\hline 1950 & 2 & 10 & 2914 \\
\hline 1950 & 9 & 10 & 2915 \\
\hline 1950 & 16 & 10 & 2916 \\
\hline 1950 & 23 & 10 & 2917 \\
\hline 1950 & 30 & 10 & 2918 \\
\hline 1950 & 4 & 12 & 2923 \\
\hline 1951 & 15 & 1 & 3003 \\
\hline 1951 & 12 & 3 & 3011 \\
\hline 1951 & 19 & 3 & 3012 \\
\hline 1951 & 26 & 3 & 3013 \\
\hline 1951 & 2 & 4 & 3014 \\
\hline 1951 & 9 & 4 & 3015 \\
\hline 1951 & 30 & 4 & 3018 \\
\hline 1951 & 7 & 5 & 3019 \\
\hline 1951 & 21 & 5 & 3021 \\
\hline 1951 & 28 & 5 & 3022 \\
\hline
\end{tabular}




\begin{tabular}{|c|c|c|c|}
\hline 1951 & 25 & 6 & 3026 \\
\hline 1951 & 23 & 7 & 3104 \\
\hline 1951 & 6 & 8 & 3106 \\
\hline 1951 & 13 & 8 & 3107 \\
\hline 1951 & 20 & 8 & 3108 \\
\hline 1951 & 24 & 9 & 3113 \\
\hline 1951 & 8 & 10 & 3115 \\
\hline 1951 & 15 & 10 & 3116 \\
\hline 1951 & 12 & 11 & 3120 \\
\hline 1951 & 19 & 11 & 3121 \\
\hline 1951 & 3 & 12 & 3123 \\
\hline 1951 & 17 & 12 & 3125 \\
\hline 1952 & 7 & 1 & 3201 \\
\hline 1952 & 25 & 2 & 3208 \\
\hline 1952 & 10 & 3 & 3210 \\
\hline 1952 & 7 & 4 & 3214 \\
\hline 1952 & 26 & 5 & 3221 \\
\hline 1952 & 9 & 6 & 3223 \\
\hline 1952 & 16 & 6 & 3224 \\
\hline 1952 & 30 & 6 & 3226 \\
\hline 1952 & 14 & 7 & 3302 \\
\hline 1952 & 21 & 7 & 3303 \\
\hline 1952 & 28 & 7 & 3304 \\
\hline 1952 & 4 & 8 & 3305 \\
\hline 1952 & 15 & 9 & 3311 \\
\hline 1952 & 22 & 9 & 3312 \\
\hline 1952 & 13 & 10 & 3315 \\
\hline 1952 & 20 & 10 & 3316 \\
\hline 1952 & 17 & 11 & 3320 \\
\hline 1952 & 29 & 12 & 3326 \\
\hline 1953 & 5 & 1 & 3401 \\
\hline 1953 & 2 & 2 & 3405 \\
\hline 1953 & 16 & 2 & 3407 \\
\hline 1953 & 9 & 3 & 3410 \\
\hline 1953 & 20 & 4 & 3416 \\
\hline 1953 & 1 & 6 & 3422 \\
\hline 1953 & 13 & 7 & 3502 \\
\hline 1953 & 27 & 7 & 3504 \\
\hline 1953 & 10 & 8 & 3506 \\
\hline 1953 & 17 & 8 & 3507 \\
\hline 1953 & 7 & 9 & 3510 \\
\hline 1953 & 14 & 9 & 3511 \\
\hline 1953 & 28 & 9 & 3513 \\
\hline 1953 & 2 & 11 & 3518 \\
\hline 1953 & 23 & 11 & 3521 \\
\hline 1954 & 4 & 1 & 3601 \\
\hline 1954 & 25 & 1 & 3604 \\
\hline 1954 & 1 & 2 & 3605 \\
\hline 1954 & 29 & 3 & 3613 \\
\hline
\end{tabular}




\begin{tabular}{|c|c|c|c|}
\hline 1954 & 5 & 4 & 3614 \\
\hline 1954 & 17 & 5 & 3620 \\
\hline 1954 & 24 & 5 & 3621 \\
\hline 1954 & 19 & 7 & 3703 \\
\hline 1954 & 13 & 9 & 3711 \\
\hline 1954 & 27 & 9 & 3713 \\
\hline 1954 & 4 & 10 & 3714 \\
\hline 1954 & 25 & 10 & 3717 \\
\hline 1954 & 15 & 11 & 3720 \\
\hline 1954 & 22 & 11 & 3721 \\
\hline 1954 & 13 & 12 & 3724 \\
\hline 1954 & 20 & 12 & 3725 \\
\hline 1954 & 27 & 12 & 3726 \\
\hline 1955 & 10 & 1 & 3802 \\
\hline 1955 & 14 & 2 & 3807 \\
\hline 1955 & 14 & 3 & 3811 \\
\hline 1955 & 28 & 3 & 3813 \\
\hline 1955 & 11 & 4 & 3815 \\
\hline 1955 & 25 & 4 & 3817 \\
\hline 1955 & 16 & 5 & 3820 \\
\hline 1955 & 23 & 5 & 3821 \\
\hline 1955 & 19 & 9 & 3912 \\
\hline 1955 & 5 & 12 & 3923 \\
\hline 1956 & 23 & 1 & 4004 \\
\hline 1956 & 6 & 2 & 4006 \\
\hline 1956 & 5 & 3 & 4010 \\
\hline 1956 & 12 & 3 & 4011 \\
\hline 1956 & 26 & 3 & 4013 \\
\hline 1956 & 9 & 7 & 4102 \\
\hline 1956 & 30 & 7 & 4105 \\
\hline 1956 & 17 & 9 & 4112 \\
\hline 1956 & 24 & 9 & 4113 \\
\hline 1956 & 1 & 10 & 4114 \\
\hline 1956 & 15 & 10 & 4116 \\
\hline 1956 & 10 & 12 & 4124 \\
\hline 1957 & 18 & 2 & 4207 \\
\hline 1957 & 4 & 3 & 4209 \\
\hline 1957 & 8 & 4 & 4214 \\
\hline 1957 & 15 & 4 & 4215 \\
\hline 1957 & 22 & 4 & 4216 \\
\hline 1957 & 6 & 5 & 4218 \\
\hline 1957 & 13 & 5 & 4219 \\
\hline 1957 & 17 & 6 & 4224 \\
\hline 1957 & 24 & 6 & 4225 \\
\hline 1957 & 19 & 8 & 4308 \\
\hline 1957 & 9 & 9 & 4311 \\
\hline 1957 & 23 & 9 & 4313 \\
\hline 1957 & 21 & 10 & 4317 \\
\hline 1957 & 28 & 10 & 4318 \\
\hline
\end{tabular}




\begin{tabular}{rrrr}
\hline 1957 & 11 & 11 & 4320 \\
1958 & 17 & 3 & 4411 \\
1958 & 24 & 3 & 4412 \\
1958 & 21 & 4 & 4416 \\
1958 & 12 & 5 & 4419 \\
1958 & 19 & 5 & 4420 \\
1958 & 26 & 5 & 4421 \\
1958 & 9 & 6 & 4423 \\
1958 & 28 & 7 & 4430 \\
1958 & 29 & 9 & 4513 \\
1958 & 20 & 10 & 4516 \\
1958 & 27 & 10 & 4517 \\
1958 & 8 & 12 & 4523 \\
1958 & 22 & 12 & 4525 \\
1959 & 19 & 1 & 4603 \\
1959 & 2 & 2 & 4605 \\
1959 & 23 & 2 & 4608 \\
1959 & 8 & 6 & 4623 \\
1959 & 3 & 8 & 4705 \\
1959 & 7 & 9 & 4710 \\
1959 & 28 & 9 & 4713 \\
1959 & 5 & 10 & 4714 \\
1959 & 12 & 10 & 4715 \\
1959 & 19 & 10 & 4716 \\
1959 & 7 & 12 & 4723 \\
1959 & 28 & 12 & 4726 \\
1960 & 11 & 1 & 4801 \\
1960 & 8 & 2 & 4805 \\
1960 & 4 & 4 & 4813 \\
1960 & 27 & 6 & 4825 \\
1960 & 15 & 8 & 4907 \\
1960 & 29 & 8 & 4909 \\
1961 & 10 & 2 & 5006 \\
1961 & 7 & 4 & 5014 \\
1961 & 16 & 6 & 5024 \\
1961 & 21 & 7 & 5103 \\
1961 & 4 & 8 & 5105 \\
1961 & 22 & 9 & 5112 \\
1961 & 29 & 9 & 5113 \\
1961 & 17 & 11 & 5120 \\
1961 & 24 & 11 & 5121 \\
1962 & 9 & 2 & 5206 \\
1962 & 30 & 3 & 5213 \\
1962 & 4 & 5 & 5218 \\
1962 & 14 & 12 & 5324 \\
1963 & 1 & 3 & 5409 \\
1963 & 5 & 4 & 5414 \\
1963 & 31 & 5 & 5422 \\
1963 & 28 & 6 & 5426 \\
\hline & & & \\
\hline
\end{tabular}

99 


\begin{tabular}{|c|c|c|c|}
\hline 1964 & 7 & 2 & 5606 \\
\hline 1964 & 8 & 5 & 5619 \\
\hline 1964 & 10 & 7 & 5702 \\
\hline 1964 & 20 & 11 & 5721 \\
\hline 1965 & 12 & 2 & 5806 \\
\hline 1965 & 19 & 2 & 5807 \\
\hline 1965 & 4 & 6 & 5822 \\
\hline 1965 & 10 & 9 & 5911 \\
\hline 1965 & 24 & 9 & 5913 \\
\hline 1965 & 8 & 10 & 5915 \\
\hline 1966 & 1 & 7 & 6101 \\
\hline 1966 & 29 & 7 & 6105 \\
\hline 1966 & 26 & 8 & 6109 \\
\hline 1966 & 2 & 9 & 6110 \\
\hline 1966 & 7 & 10 & 6115 \\
\hline 1967 & 25 & 8 & 6308 \\
\hline 1967 & 24 & 11 & 6321 \\
\hline 1968 & 29 & 3 & 6413 \\
\hline 1968 & 14 & 6 & 6424 \\
\hline 1968 & 28 & 6 & 6426 \\
\hline 1968 & 18 & 10 & 6516 \\
\hline 1970 & 20 & 11 & 6921 \\
\hline 1970 & 11 & 12 & 6924 \\
\hline 1971 & 19 & 2 & 7006 \\
\hline 1971 & 19 & 3 & 7010 \\
\hline 1971 & 9 & 4 & 7013 \\
\hline 1971 & 2 & 7 & 7101 \\
\hline 1971 & 6 & 8 & 7106 \\
\hline 1971 & 13 & 8 & 7107 \\
\hline 1972 & 11 & 2 & 7205 \\
\hline 1972 & 25 & 2 & 7207 \\
\hline 1972 & 23 & 6 & 7224 \\
\hline 1972 & 4 & 8 & 7305 \\
\hline
\end{tabular}




\section{Bibliography}

\section{Books}

Baughman, James L. Henry R. Luce and the Rise of the American News Media. Baltimore: The Johns Hopkins University Press, 2001.

Bethune, Beverly M. and Mimi Fuller Foster, eds. Women in Photojournalism. Durham: National Press Photographers Association, 1986.

Cartier-Bresson, Henri. The Mind's Eye: Writings on Photography and Photographers. New York: Aperture, 1999.

Caujolle, Christian and Mary Panzer. Things As They Are: Photojournalism in Context since 1955. New York City: Aperture, 2005.

Doss, Erika, ed. Looking at Life Magazine. Washington and London: Smithsonian Institute Press, 2001.

Flamiano, Dolores. Women, Workers, and Race in LIFE Magazine: Hansel Mieth's Reform Photojournalism, 1934-1955. Abingdon: Routledge, 2016.

Gervais, Thierry with the collaboration of Gaëlle Morel. The Making of Visual News. London: Bloomsbury, 2017.

Hadland, Adrian, David Campbell and Paul Lambert. The State of News Photography: The Lives and Livelihoods of Photojournalists in the Digital Age. Amsterdam: World Press Photo, 2015.

Hicks, Wilson. Words and Pictures. New York: Harper \& Brothers Publishers, 1952.

Hill, Jason and Vanessa R. Schwartz. Getting the Picture: The Visual Culture of the News. London and New York: Bloomsbury, 2015.

Hurm, Gerd, Anke Reitz, and Shamoon Zamir, ed. The Family of Man Revisited: Photography in a Global Age. London: I.B. Tauris \& Co. Ltd, 2018.

Kahmen, Volker. Art History of Photography. Translated by Brian Tubb. New York: Viking Press, 1974.

Kozol, Wendy. Life's America: Family and Nation in Postwar Photojournalism. Philadelphia: Temple University Press, 1994.

Lebeck, Robert and Bodo von Dewitz. Kiosk: A History of Photojournalism. Göttingen: Steidl, 2001. 
Loengard, John, ed. Life Photographers: What They Saw. Boston: Bulfinch Press, 1998.

Curtis Prendergast with Geoffrey Colvin. The World of Time Inc.: The Intimate History of a Changing Enterprise: 1960-1980. New York: Atheneum, 1986.

Rosenblum, Naomi. A History of Women Photographers. New York: Abbeville Press, 2010.

Sumner, David E. The Magazine Century: American Magazines since 1900. New York: Peter Lang Publishing, Inc., 2010.

Wainwright, Loudon. The Great American Magazine: An Inside History of Life." New York City: Knopf, 1986.

\section{Book Chapters}

Bair, Nadya. "Never Alone: Photo Editing and Collaboration." In Getting the Picture: The Visual Culture of the News, edited by Jason E. Hill and Vanessa R. Schwartz, 228-235. London: Bloomsbury, 2015.

Barthes, Roland. “The Photographic Message.” In Image-Music-Text, translated by Stephen Heath, 15-31. New York: Hill \& Wang, 1977.

Baughman, James L. "Who Read Life? The Circulation of America's Favorite Magazine.” In Looking at Life Magazine, edited by Erika Doss, 41-54. Washington and London: Smithsonian Institute Press, 2001.

Burke, Peter. "The Cultural History of Images." In Eyewitnessing: The Uses of Images as Historical Evidence, 178-190. London: Reaktion Books, 2001.

Codrescu, Andrei and Terence Pitts. “Otto Hagel \& Hansel Mieth.” In Reframing America, 30-49. Tucson: The Center for Creative Photography, 1995.

De Young, Justin. "Not Just a Pretty Picture: Fashion as News." In Getting the Picture, edited by Jason E. Hill and Vanessa R. Schwartz, 228-235. London: Bloomsbury, 2015.

The Editors of Life. "Nina Leen." In The Great Life Photographers, edited by John Loengard and Gordon Parks, 308-315. New York: Time Warner Book Group, 2004.

Edwards, Elizabeth and Janice Hart. "Introduction: Photographs as Objects." In Photographs Objects Histories: On the Materiality of Images, edited by Elizabeth Edwards and Janice Hart, 1-15. Abingdon: Routledge, 2004. 
Hardt, Hanno and Bonnie Brennen. "Newswork, History, and Photographic Evidence: A Visual Analysis of the 1930s Newsroom.” In Picturing the Past: Media, History \& Photography, edited by Bonnie Brennen and Hanno Hardt, 11-35. Urbana and Chicago: University of Illinois Press, 1999.

Haskell, Francis. "Introduction." In History and its Images: Art and the Interpretation of the Past, 1-12. New Haven and London: Yale University Press, 1993.

Maurer, Trude. "Education and Vocational Training." In Jewish Daily Life in Germany, 1618-1945, edited by Marion A. Kaplan and translated by Allison Brown, 291-305. Oxford: Oxford University Press, 2005.

Maurer, Trude. "Constricting and Extinguishing Jewish Life.” In Jewish Daily Life in Germany, 1618-1945, edited by Marion A. Kaplan and translated by Allison Brown, 346-373. Oxford: Oxford University Press, 2005.

Kracauer, Siegfried. “The Historical Approach.” In History: The Last Things Before the Last, 45-61. New York: Oxford University Press, 1969.

Loengard, John. "The Ambition Behind This Book." In The Great Life Photographers, edited by John Loengard and Gordon Parks, 6-11. New York: Time Warner Book Group, 2004.

Mendelson, Jordana. "Beautiful Contradictions: News Pictures and Modern Magazines." In Getting the Picture: The Visual Culture of the News, edited by Jason E. Hill and Vanessa R. Schwartz, 154-160. London: Bloomsbury, 2015.

Nochlin, Linda. "Why Have There Been No Great Women Artists?" In Women, Art and Power and Other Essays, 147-158. Boulder: Westview Press, 1988.

Smith, Terry. “LIFE-Style Modernity: Making Modern America.” In Looking at Life Magazine, edited by Erika Doss, 25-40. Washington and London: Smithsonian Institute Press, 2001.

Solinger, Rickie. “The Smutty Side of Life: Picturing Babes as Icons of Gender Difference." In Looking at Life Magazine, edited by Erika Doss, 201-220. Washington and London: Smithsonian Institute Press, 2001.

Solomon-Godeau, Abigail. "Inventing Vivian Maier: Categories, Career, and Commerce (2013).” In Photography After Photography: Gender, Genre, History, edited by Sarah Parsons, 141-155. Durham and London: Duke University Press, 2017.

Tyler May, Elaine. "Introduction." In Homeward Bound: American Families in the Cold War Era, 1-18. New York: Basic Books, 2008.

Wexler, Laura. “Introduction.” In Tender Violence: Domestic Visions in an Age of U.S. Imperialism, 1-14. Chapel Hill: The University of North Carolina Press, 2000. 


\section{Journal Articles and Dissertations}

Blaschke, Estelle. "Photography and the Commodification of Images: From the Bettman Archive to Corbis (ca. 1924-2010)." PhD Diss., École des Hautes Études en Sciences Sociales, 2011.

Buurman, Nanne. "Engendering Exhibitions: The Politics of Gender in Negotiating Curatorial Authorship.” Journal of Curatorial Studies 6, no. 1 (April 2017): 115138.

Chang, Yin-Ren and Martin Richardson. "Drawing Lines with Light in Holographic Space.” Journal of Physics: Conference Series 415, no. 1 (2013): 1-7.

Edwards, Elizabeth. "Material beings, Objecthood and Ethnographic Photographs." Visual Studies 17, no. 1 (2002): 67-75.

Flamiano, Dolores. “A Life of Their Own: Hansel Mieth's Photographic Essays.” Media History Monographs 7 (2004): 1-29. http://facstaff.elon.edu/dcopeland/mhm/mieth.pdf.

Hermanson, Sarah. “Henri Cartier-Bresson.” MoMA 3, no. 6 (September 2000): 31-32.

Krauss, Rosalind. "Photography's Discursive Spaces: Landscape/View." In Art Journal 42, no. 4 (Winter 1982): 311-319.

Linssen, Dalia Habib. "Imprints of Their Being: The Photographs of Hansel Mieth and Otto Hagel.” PhD Diss., Boston University, 2010.

Martin, Richard. "Style from Paris, Reality from America: Fashion in Life Magazine, 1947-1963." The Journal of American Culture 19, no. 4 (December 1996): 51-55.

Paglen, Trevor. "Friends of Space, How Are You All? Have You Eaten Yet? Or, Why Talk to Aliens Even if We Can't." In Afterall: A Journal of Art, Context, \& Enquiry 32, no. 1 (Spring 2013): 8-19.

Ream, Tim. “The Life of Werner Wolff: An Analysis of Werner Wolff's Contributions to Life Magazine." Masters thesis, Ryerson University and George Eastman House, 2014.

Santana, Maria Cristina. "From Empowerment to Domesticity: The Case of Rosie the Riveter and the WWII Campaign." Frontiers in Sociology 1, no. 16 (December 2016): 1-8.

Sherry Riccihardi. "Getting the Picture." American Journalism Review 20, no. 1 (January/February 1998): 26-32. 
Smith, Cynthia Zoë. "Émigré Photography in America: Contributions of German Photojournalists from Black Star Picture Agency to Life Magazine." PhD Diss., The University of Iowa, 1983.

Szarkowski, John. "Photography and the Mass Media." Aperture 13, no. 3 (1967): 51-53.

Webb, Sheila. "Creating Life: America's Most Potent Editorial Force.” Journalism \& Communication Monographs 18 (2016): 55-108.

Wilson, Beth E. "The Corporate Creation of the Photojournalist: LIFE Magazine and Margaret Bourke-White in World War II." Journal of War \& Culture Studies 9, no. 2 (May 2016): 133-150.

\section{Web Sources}

Coleman, Chloe. "This Photographer who Documented Professional Pioneers was a Pioneer Herself." Washington Post, October 21, 2016, accessed May 20, 2018. https://www.washingtonpost.com/news/in-sight/wp/2016/10/21/thisphotographer-who-documented-professional-pioneers-was-a-pioneerherself/?utm_term=.d03c312501b9.

Cosgrove, Ben. “LIFE: Revisiting 'American Elegance' in 1950s Fashion.” Time Life, October 22, 2012, accessed May 20, 2018.

http://time.com/3878998/life-revisiting-american-elegance-in-1950s-fashion/

"Degenerate Art." MoMA, accessed March 12, 2018. https://www.moma.org/calendar/exhibitions/3868.

Dunlap, David W. "Time Inc.'s Record of the $20^{\text {th }}$ Century, in Thousands of Boxes, is Moving." The New York Times. November 5, 2015, accessed March 1, 2017. https://www.nytimes.com/2015/11/06/nyregion/time-incs-record-of-the-20thcentury-in-thousands-of-boxes-is-moving.html?_r=1.

“The Family of Man,” MoMA, accessed May 1, 2018. https://www.moma.org/calendar/exhibitions/2429.

“The Golden Record.” Voyager. NASA, accessed November 1, 2017. https://voyager.jpl.nasa.gov/golden-record.

"Guide to the Time Inc. Bio Files MS 3009.RG 2." New-York Historical Society Museum and Library. Last modified March 27, 2017, accessed April 1, 2017. http://dib.nyu.edu/findingaids/html/nyhs/timeincrg2/scopecontent.html.

"Images on the Golden Record," Voyager, NASA, accessed April 20, 2018. https://voyager.jpl.nasa.gov/galleries/images-on-the-golden-record/. 
Josten, Alicia. "Nina Leen." International Center of Photography, accessed October 11, 2017. https://www.icp.org/browse/archive/constituents/nina-leen?all/all/all/all/0.

Los Angeles Times Staff Writer. "Alvin Novick, 79; Was Expert on Bats, Led Efforts to Fight AIDS.” Los Angeles Times, April 24, 2005, accessed May 1, 2018. http://articles.latimes.com/2005/apr/24/local/me-novick24.

“The Loving Story.” International Center of Photography, 2012, accessed May 18, 2018. https://www .icp.org/exhibitions/the-loving-story-photographs-by-grey-villet.

Nakano, Craig. "1960s Life Magazine Photos of the 'Loving' Couple, on View at Photo L.A.” L.A. Times, December 29, 2016, accessed May 18, 2018. http://www.latimes.com/entertainment/arts/la-ca-cm-loving-photos-20170101htmlstory.html.

“Nina Leen.” MoMA, accessed November 1, 2017. https://www.moma.org/artists/42293.

"Nina Leen is Dead; a Photographer." The New York Times, January 5, 1995, Accessed November 15, 2018. http://www.nytimes.com/1995/01/05/obituaries/nina-leen-isdead-a-photographer.html.

O’Reilly, John. "Tragedy in India." Sports Illustrated, April 11, 1955, accessed June 2, 2018. https://www.si.com/vault/1955/04/11/619945/tragedy-in-india.

Pomerantz, James. “The Surreal World of Nina Leen.” The New Yorker, April 11, 2013, Accessed November 15, 2018.

https://www.newyorker.com/culture/photo-booth/the-surreal-world-of-nina-leen.

Ronk, Liz. "Photographer Spotlight: Nina Leen.” Time Life, November 18, 2012, accessed November 15, 2018. http://time.com/3506134/photographer-spotlightnina-leen.

Rosenberg, David. "The Mysterious Life Magazine Photographer Who Loved Animals." Slate, March 15, 2015, accessed November 15, 2018. http://www.slate.com/blogs/behold/2015/03/15/nina_leen_a_mysterious_person_a nd_a_prolific_photographer_of_animals_and.html.

Schiller, Jakob. "Beloved High-Speed Film Camera Faces Extinction.” Wired. August 22, 2012. https://www.wired.com/2012/08/hulcher-high-speed-cameras.

Smithson, Aline. "Nina Leen, Lensady." Lenscratch, April 3, 2015, accessed November 15, 2018. http://lenscratch.com/2015/04/nina-leen-lenslady/. 


\section{Self-Published Books by Nina Leen}

Leen, Nina and Ray Mackland. Lucky, the Famous Foundling. New York, A. A. Wyn, 1951.

Novick, Alvin and Nina Leen. The World of Bats. Lausanne: Edita, 1969.

Leen, Nina. Women, Heroes and a Frog. New York: W.W. Norton, 1970.

Leen, Nina and Joseph Anthony Davis. And Then There Were None: America's

Vanishing Wildlife. New York: Holt, Rinehart and Winston, 1973.

Leen, Nina. Dogs of All Sizes. Garden City: Amphoto, 1974.

Leen, Nina. Love, Sunrise and Elevated Apes. New York: Norton, 1974.

Leen, Nina. Sandikins. New York: Holt, Rinehart and Winston, 1975.

Leen, Nina. The Bat. New York: Holt, Rinehart and Winston, 1976.

Leen, Nina. Images of Sound. New York: Norton, 1977.

Leen, Nina. Taking Pictures. New York: Avon, 1977.

Leen, Nina. Monkeys. New York: Holt, Rinehart and Winston, 1978.

Leen, Nina. Snakes. New York: Holt, Rinehart and Winston, 1978.

Leen, Nina. What Kind of a Dog is That? New York: Norton, 1979.

Leen, Nina. Cats. New York: Holt, Rinehart and Winston, 1980.

Leen, Nina. Rare and Unusual Animals. New York: Holt, Rinehart and Winston, 1981.

\section{Life Articles Discussed in Text Featuring Photographs by Nina Leen}

“Slacks," Life, April 20, 1942, 63-69.

"Women Lose Pockets and Frills to Save Fabrics," Life, April 20, 1942, 70-71.

“Pet Squirrel," Life, January 31, 1944, 93-96.

“The World of Washington Irving," October 30, 1944, 63-71.

“Teen-Age Girls,” Life, December 11, 1944, 91-99. 
“Sub-Deb Clubs," Life, April 2, 1945, 87-93.

“Spring Fashions," Life, April 12, 1948, 90-93.

“The American Family in Trouble," Life, July 26, 1948, 84-95.

“Summer Beach Fashions,” Life, May 15, 1950, 138-144.

“The Metropolitan and Modern Life," Life, January 15, 1951, 34.

"Dazzling Collection of Pheasants from Asia is Assembled in North Carolina," Life, October 15, 1956, 123-126.

"Zoo Season in the Sun," Life, April 22, 1957, 72-76.

"Ghostly American Legends: The Early Tales Die Hard Even in This Skeptical Age," Life, October 28, 1957, 86-97.

"Five Views of a Marriage from Members of the Wedding," Life, July 28, 1958, 73-79.

“A Rare Picture Visit: The First Lady at Home," Life, October 20, 1958, 60-65

“A Picture Portrayal of Moments of Happiness," Life, October 27, 1958, 86-95.

“Strange World of Snakes," Life, March 1, 1963, 37-54.

“The Strange World of Bats," Life, March 29, 1968, 52-65.

\section{Other Life Articles Discussed in Text}

"Rainbow Realm of Tropic Insects," Life, November 3, 1958, 54-70. Photographs by Dmitri Kessel, Rudolf Freund, Edward Ross, H.B.D. Kettlewell, and Walter Sanders.

"Hypnosis: Out of Ancient Magic Comes a New Medical Tool," Life, November 3, 1958, 112-124. Photographs by Philippe Halsman, George Du Maurier, Jon Brenneis, Albert Fenn, Stan Wayman, Thomas MacAvoy, Leonard McCombe, and Carl Mydans.

“The Crime of Being Married," Life, March 18, 1966, 85-91. Photographs by Grey Villet. 